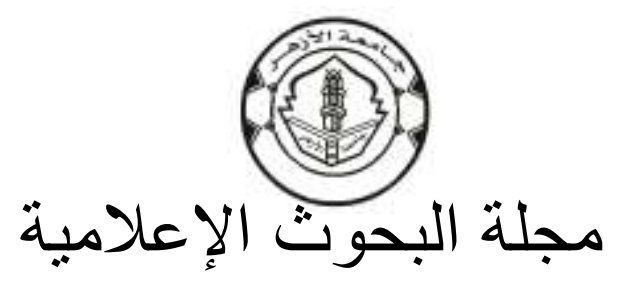

مجلة علمية محكمة تصدر عن جامعة الأزهر

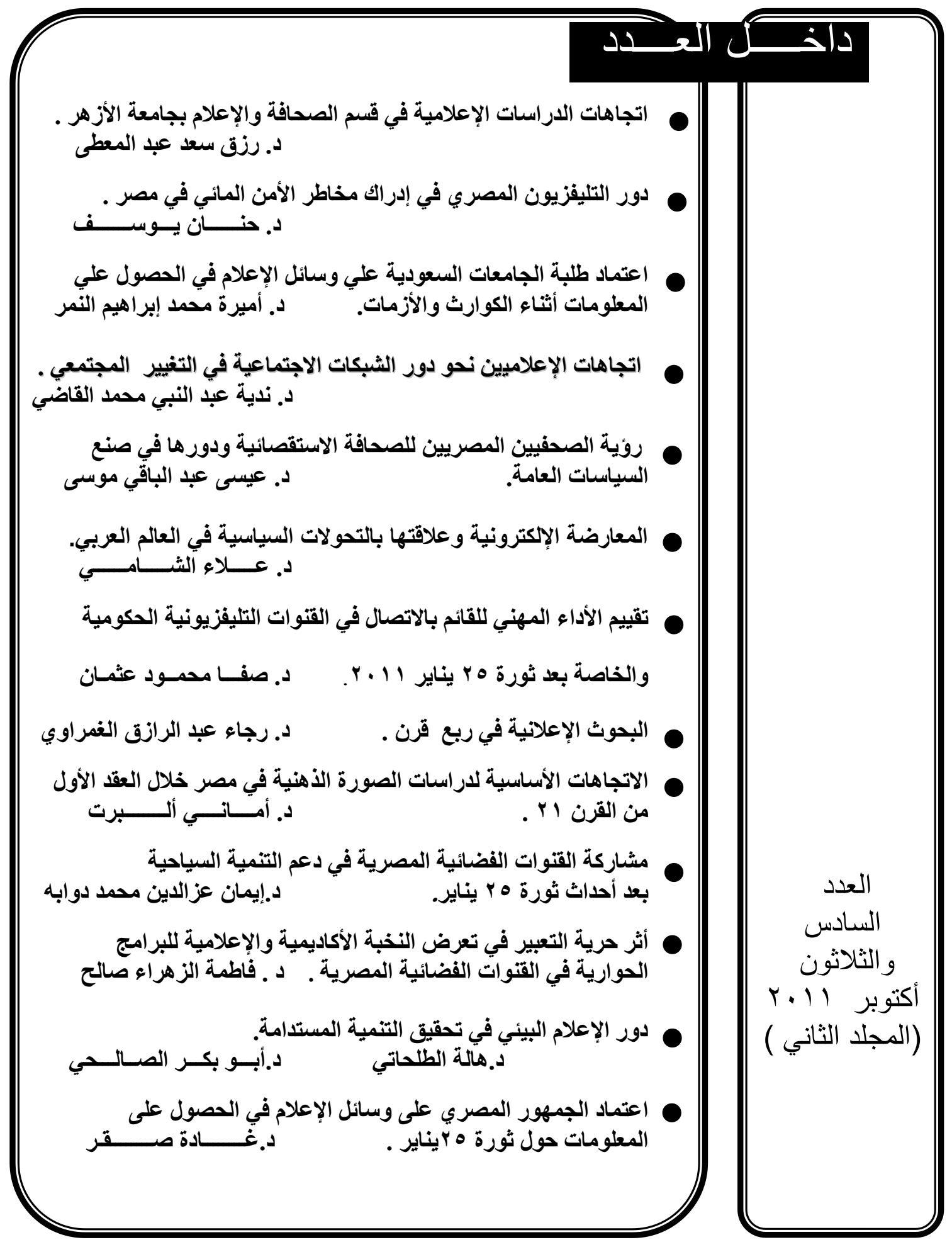




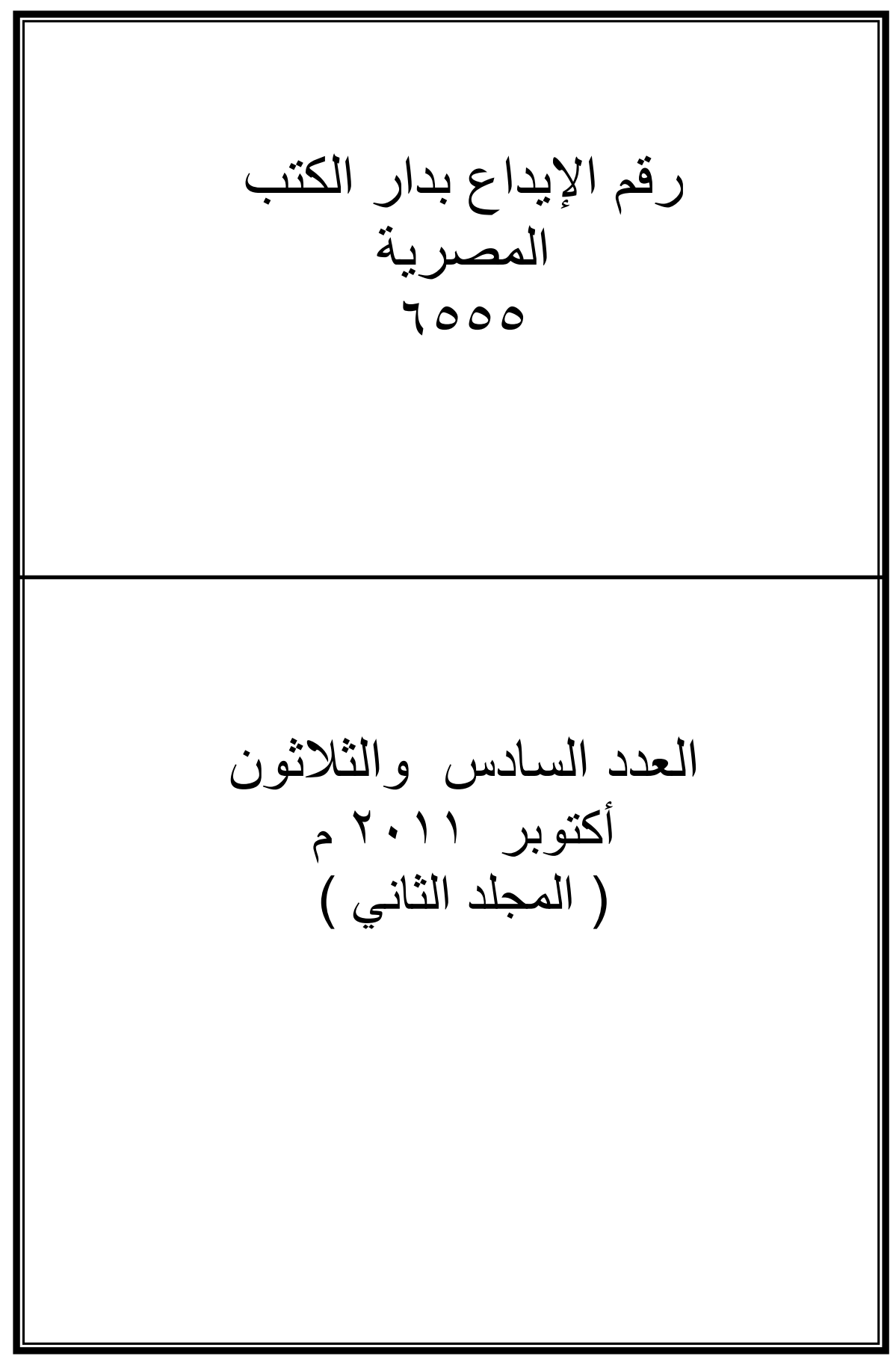




$$
\text { البحوثة الإعلامية }
$$

مجلة علمية محكمة تصدر عن جامعة الأزهر

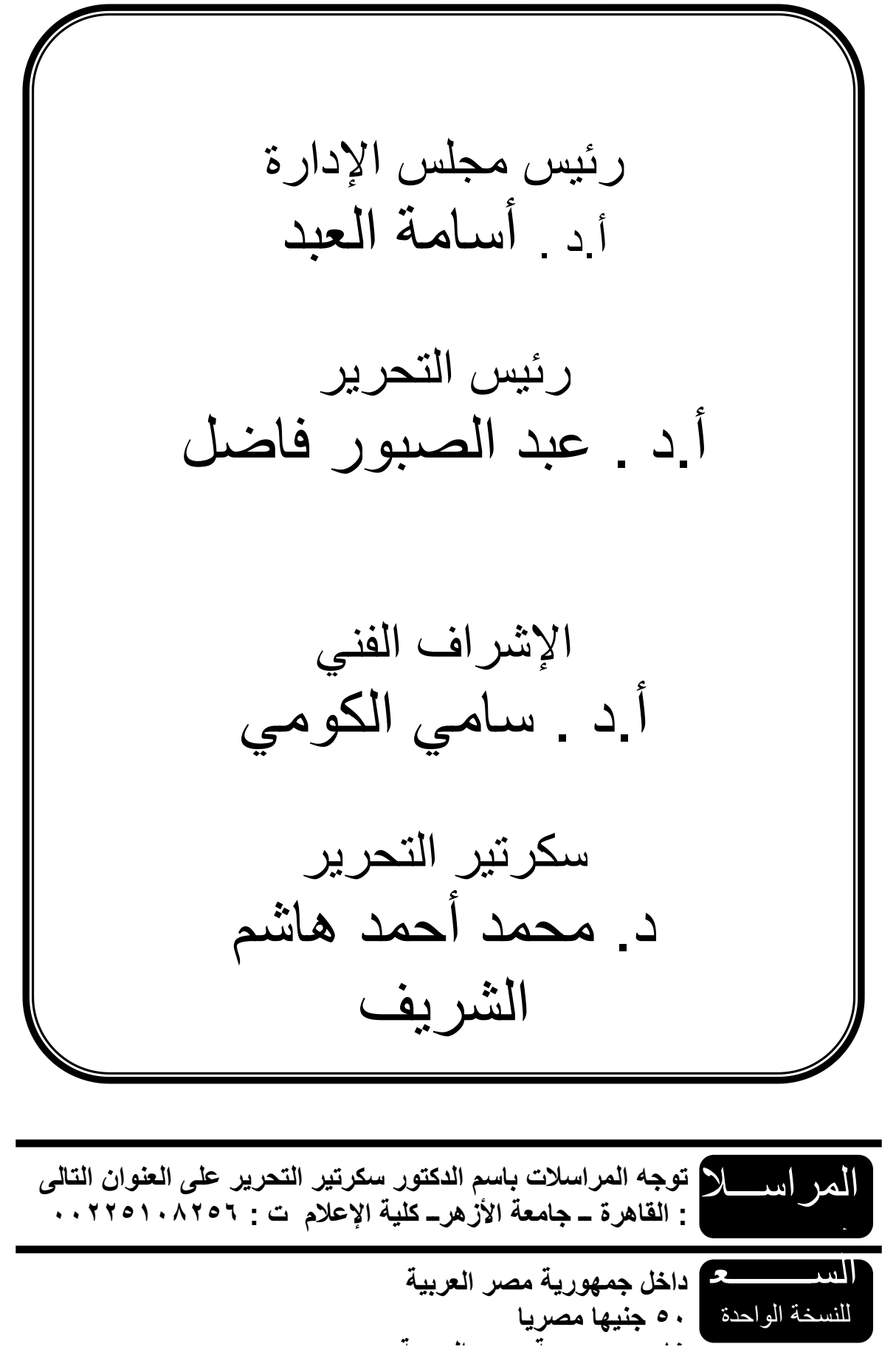


هيئــة المحكمبــن

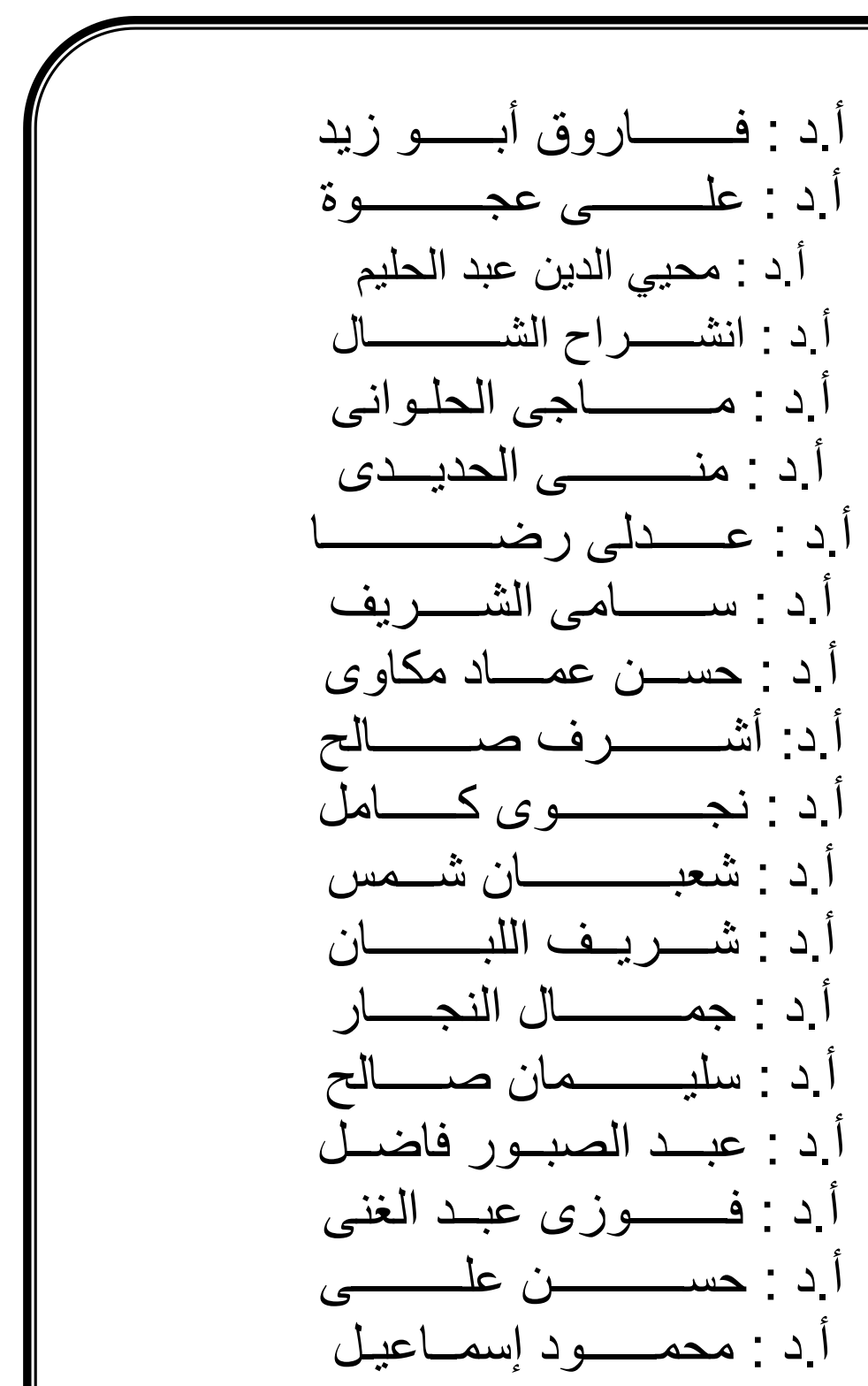

جميع الآراء الواردة فى المجلة تعبر عن رأى أصحابها و لا تعبر عن رأى المجلة

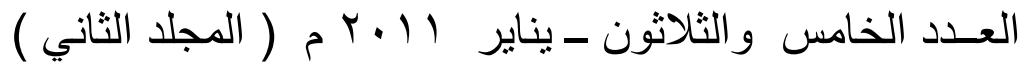


فهــرس المحتويات

\begin{tabular}{|c|c|}
\hline |رقم الصفحـــة & المحت المت \\
\hline $\begin{array}{c}1 \\
1 \\
\varepsilon \\
1\end{array}$ & 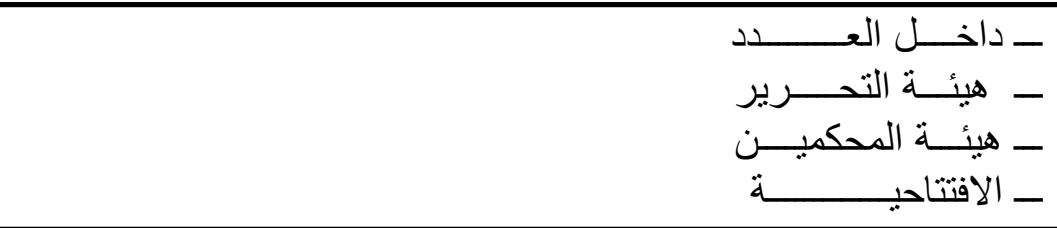 \\
\hline$\varepsilon r-q$ & اتجاهات الدراسات الإعلامية في قسم الصحافة والإعلام بجامعة الأزهر . \\
\hline$\Lambda)-\leqslant$ & 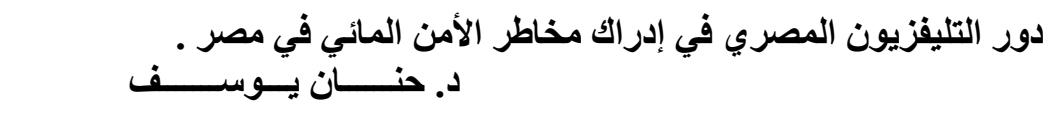 \\
\hline $1 r q-\Lambda r$ & 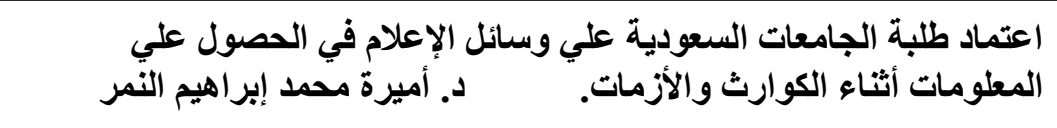 \\
\hline$|v 0-|{ }_{1}$ & اتجاهات الإعلاميين نحو دور الثبكات الاجتماعية في التغيير المجتمعي . التقاضي \\
\hline$r r_{0}-I V V$ & 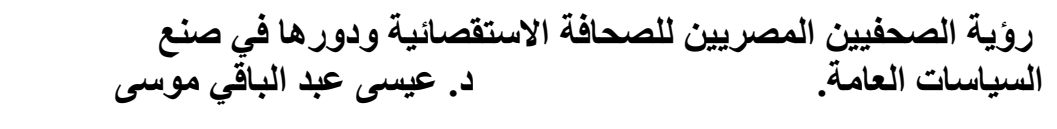 \\
\hline$r V V-r M V$ & المعارضة الإكترونية وعلاقتها بالتحولات السياسية في العالم العربي. \\
\hline$r r v-r v q$ & تقبيم الأداء المهني للقائم بالاتصال في القتوات التليفزيونية الحكومية والخاصة \\
\hline$r \wedge 0-r r q$ & البحوث الإعلانية في ربع قرن . \\
\hline$\varepsilon \varepsilon \tau-r \wedge V$ & 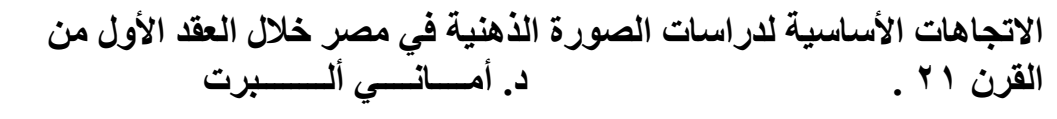 \\
\hline$\varepsilon V V-\varepsilon \varepsilon V$ & 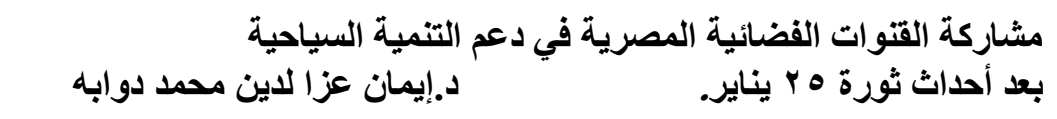 \\
\hline $01 \cdot-\leqslant \vee q$ & 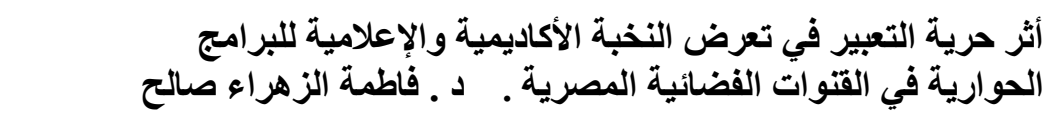 \\
\hline $07 r-011$ & 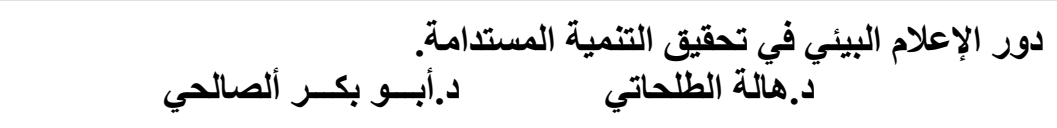 \\
\hline $09 \leq-07 \pi$ & 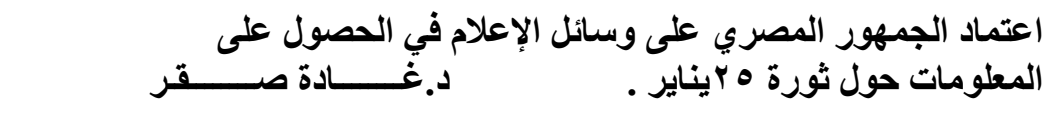 \\
\hline
\end{tabular}


اتجاهات الاراسات الإعلامية في قسم الصحافة والإعلام بجامعة الأزهر

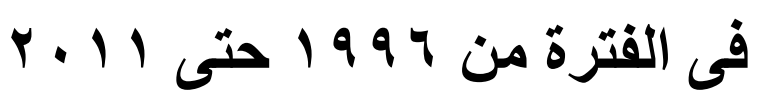

$$
\text { دأستاذ الإعلام المبداعد المعطي }
$$




\section{مقدمة: مقة}

تأتي هذه الدر اسة في إطار سلسلة الدر اسات الر ائدة التي بدأتها كلية الإعلام منذ فترة ليست

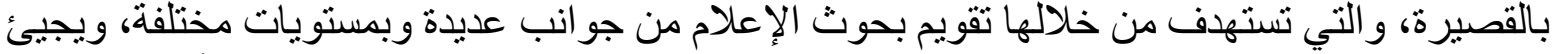

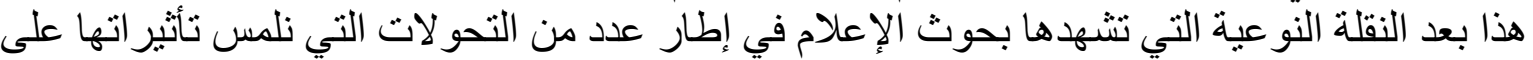

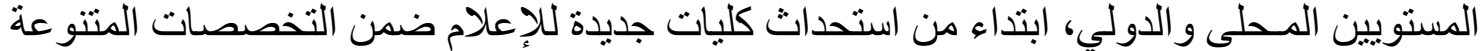

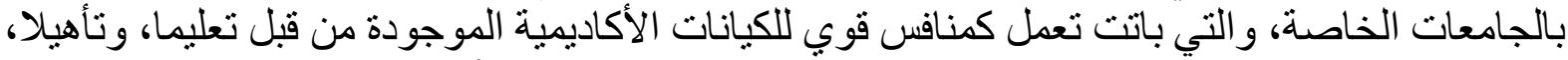

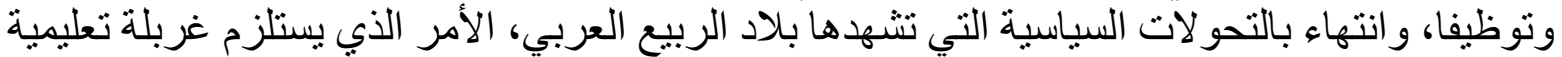

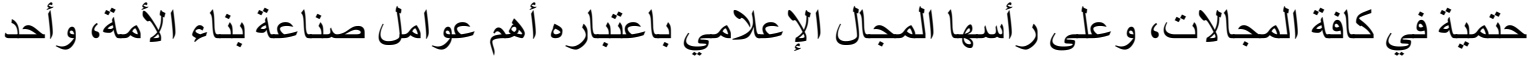
متغير ات التأثنير فيها.

نضيف إلى مـا سبق تز اوج تكنولوجيا المعلومـات والاتصـال وبروز أشكال جديدة للتكنولوجيا

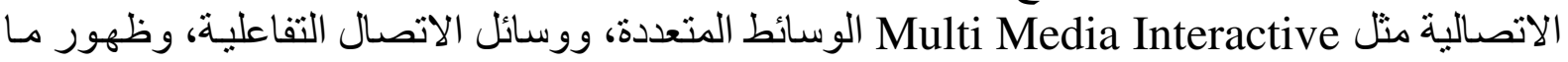

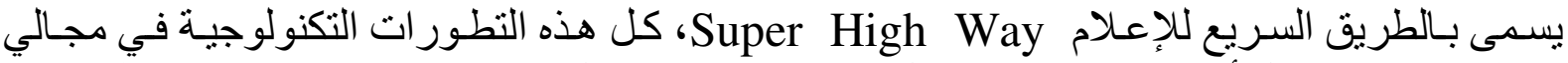

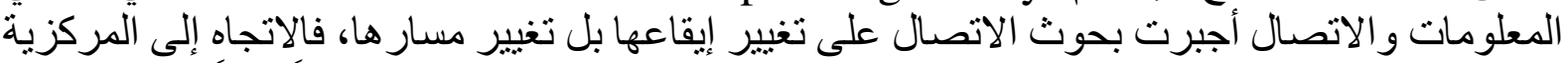

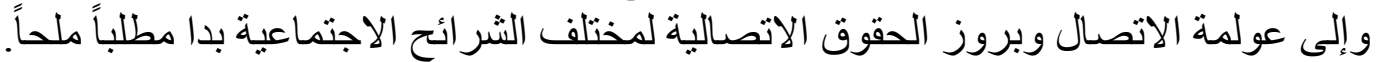

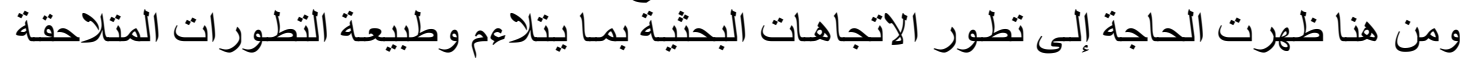

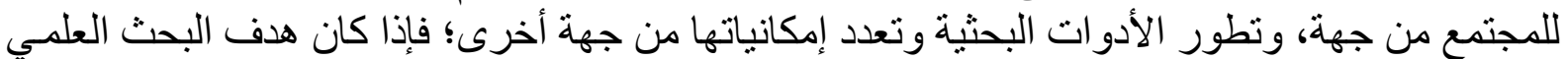

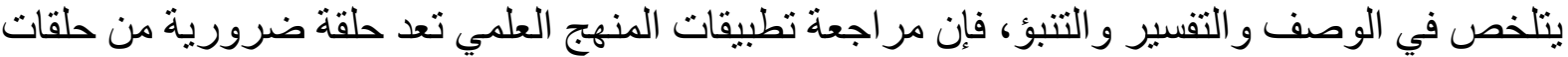

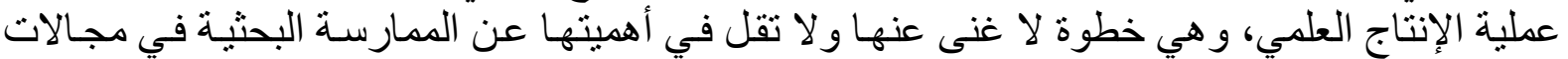

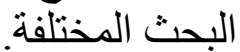

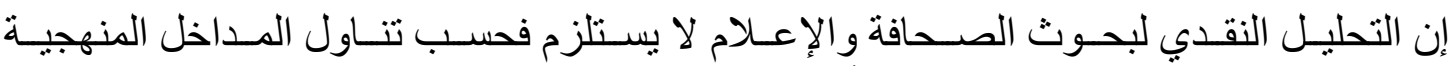

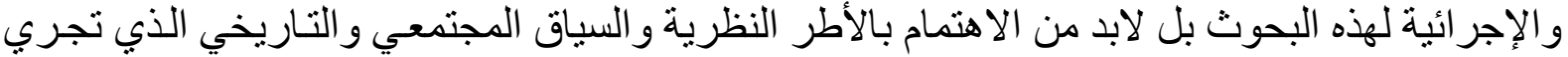

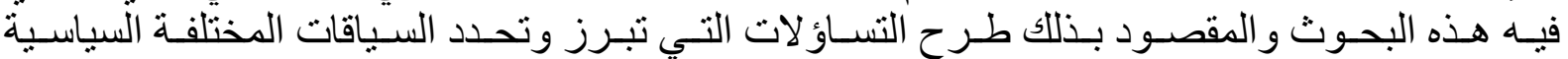

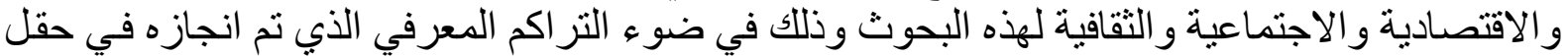

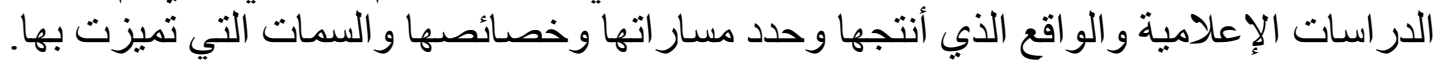

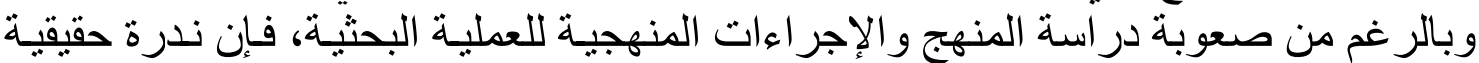

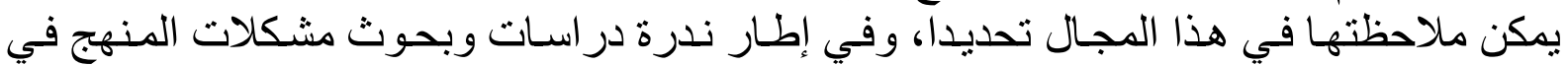

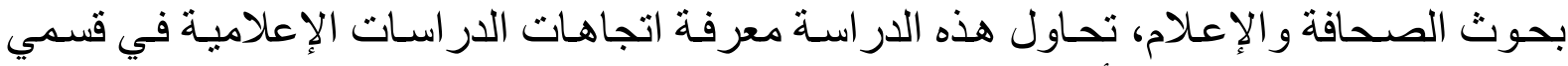

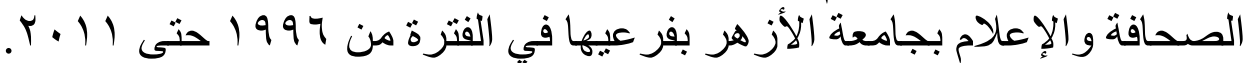

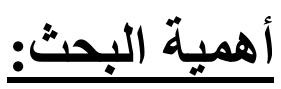

إن در اسة مشكلات المنهج في العلوم الاجتماعية تبدو ضرورة ملحة لاسيما في ظل التطور

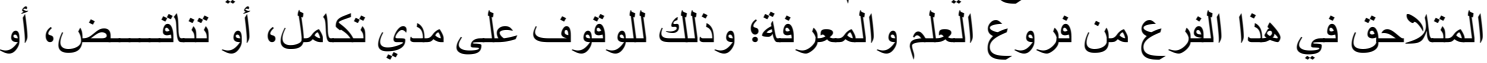
تكر ار التر اكم المعرفي الناجم عن تنوع الدر اسات الإعلامية، و اتساع مجالاتها النظرية و التطبيقية. 
كما تمثل هذه الدر اسة المحاولة الثانية لمسح ثمرة الجهود العلمية للباحثين في حقل در اسات الإعلام

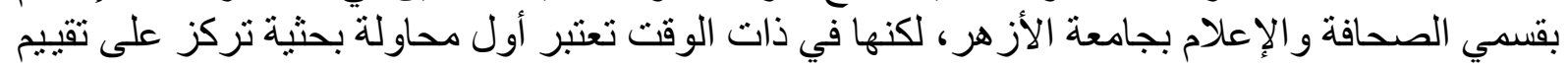

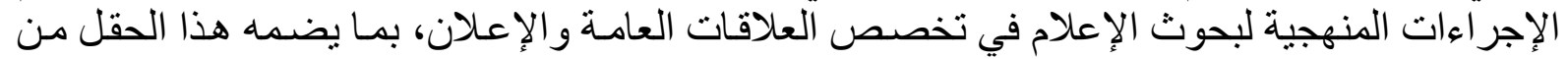

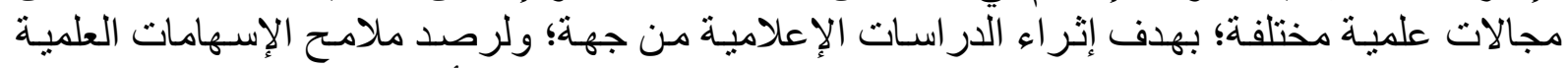

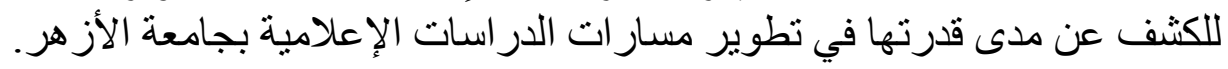

\section{هدف البحث:}

1 - تهدف هذه الورقة البحثية إلى وصف وتحليل ونقد الوضع الراهن للار اسات الإعلامية في

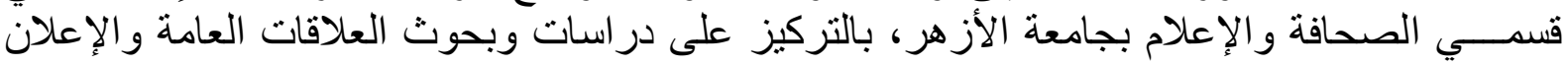

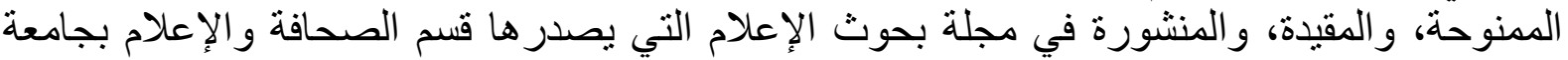

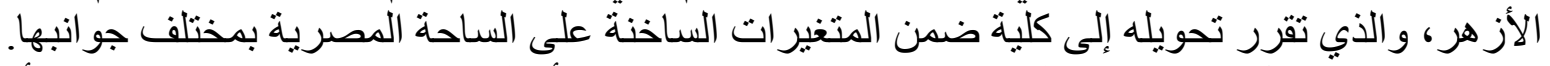

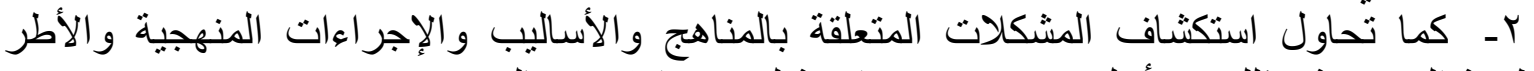

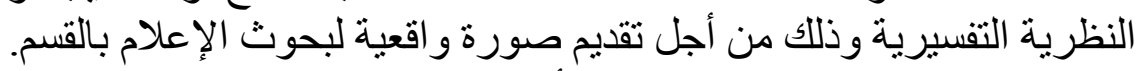

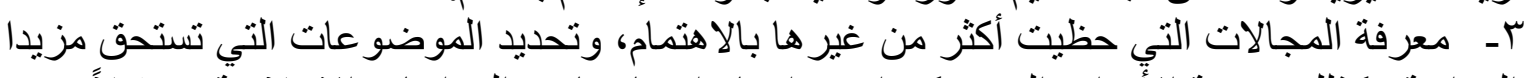

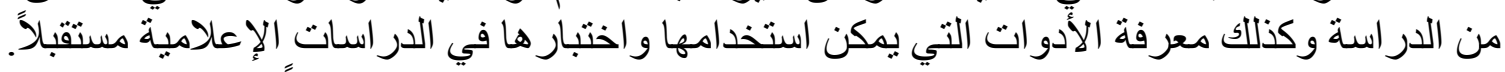

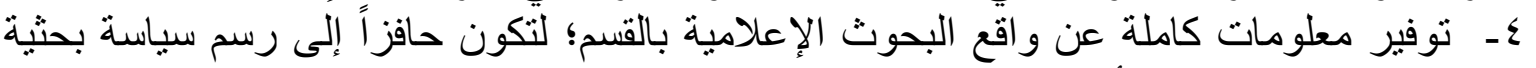

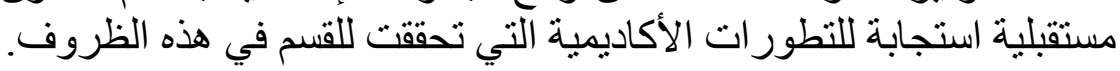

\section{منهج البحث:}

ينتمي هذا البحث إلى حقل الدر اسات الوصفية التي تتعدى مرحلة الرصد إلى التحليل و التقويم

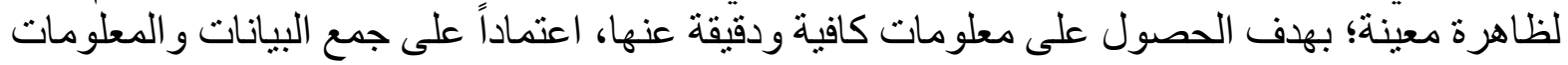

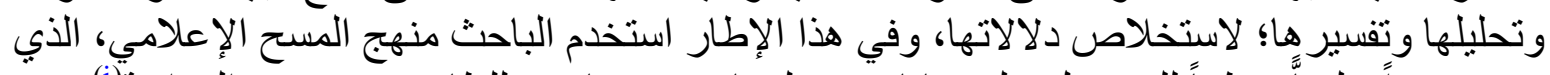

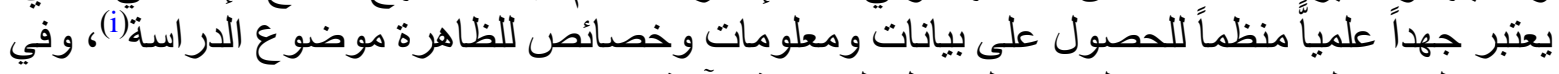

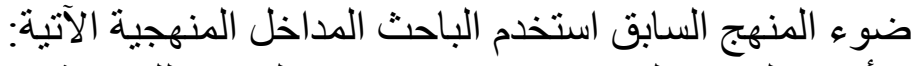

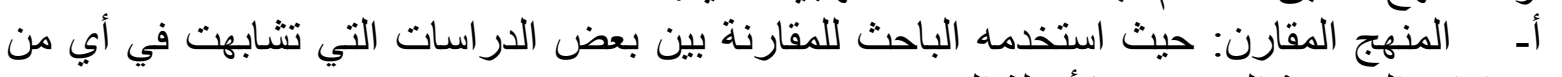

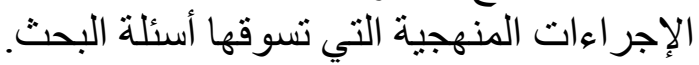

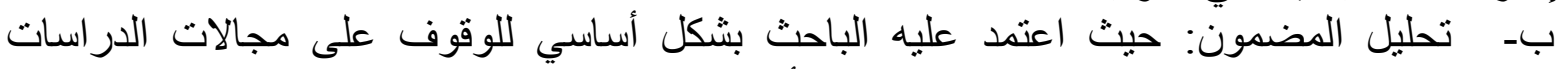

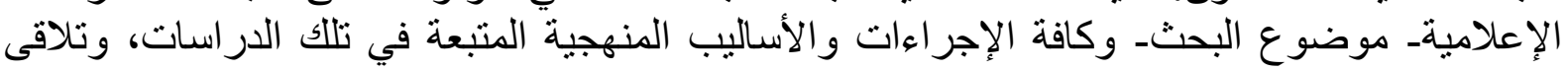
ذللك مع تحليل كيفي للالالات و المؤشر ات التي يعكسها الرصد الكوات الكمي لكافة متغيرات البحثة.

\section{تساؤلات البحث:}

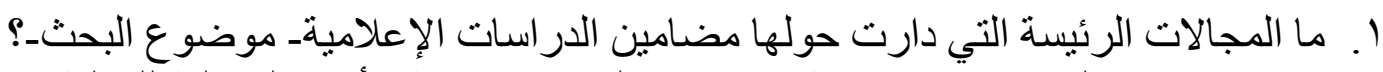

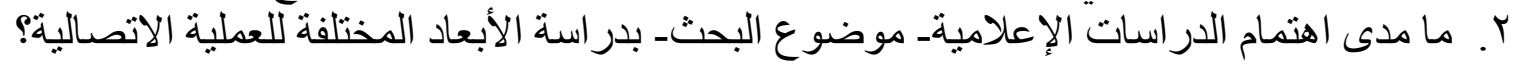




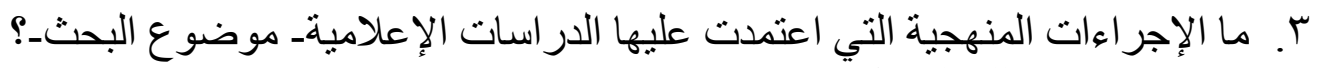

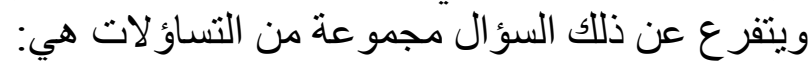

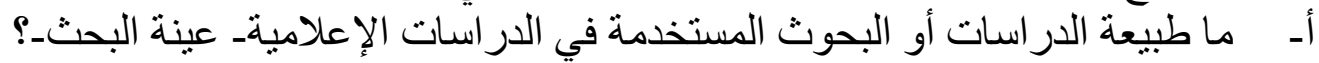

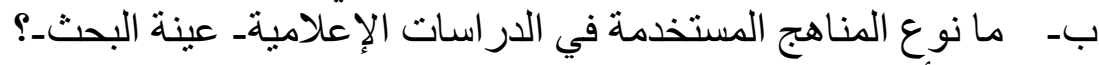

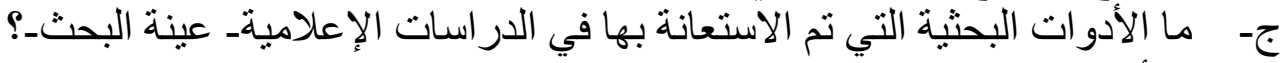

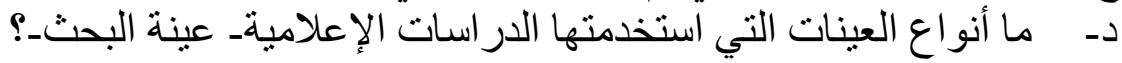

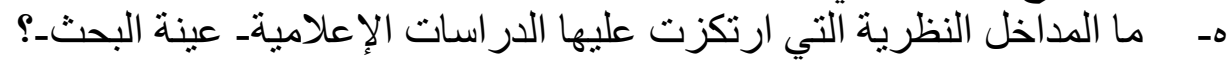

و - ما المقاييس الإحصائية التي تم الاعتماد عليها في تفسير نتائج الدر اسات الإعلامية الإنــ عينة البحث؟

\section{مجنمع البحث: : 20}

يتحدد مجتمع البحث في كافة الرسائل العلمية و الخطط البحثية لدرجتي (ماجستير - ودكتور اه)،

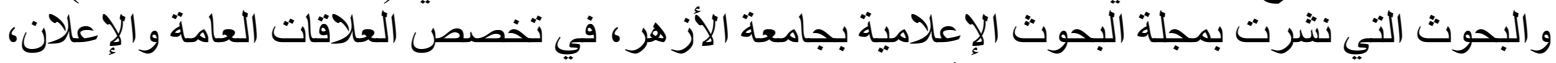

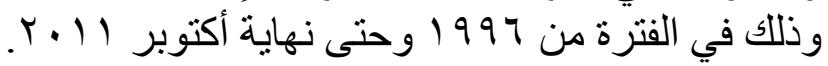

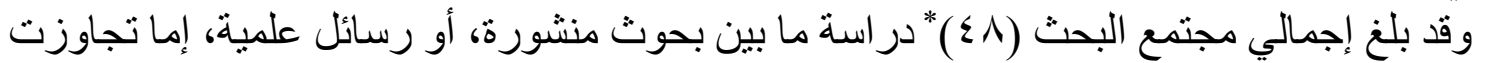

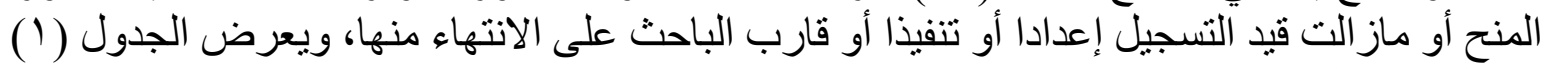
جدول ( ) مجتمع الاراسة

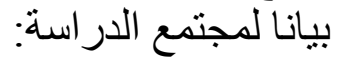

\begin{tabular}{|c|c|c|c|}
\hline$\%$ & التكرار & مجتمع الدراسة & م \\
\hline $0 r_{.1}$ & ro & بحث منشور في مجلة علمية & .1 \\
\hline rY.q & 11 & خطة مسجلة لارجة الماجستير &.$r$ \\
\hline 17.8 & $\Lambda$ & رسائل ماجستير & $r$ \\
\hline $7 . \%$ & $r$ & رسائل دكتوراه &.$\xi$ \\
\hline Y.l & 1 & خطة مسجلة لدرجة الدكتوراه & $0^{\circ}$ \\
\hline $1 \ldots$ & $\varepsilon \wedge$ & Total & \\
\hline
\end{tabular}

من بيانات جدول ( ) - 1 نستتتج ما يلي:

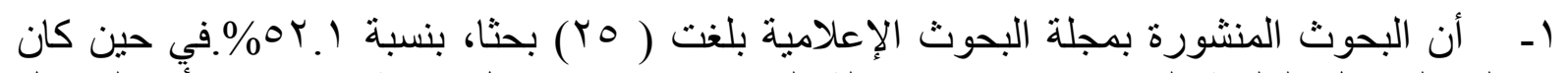

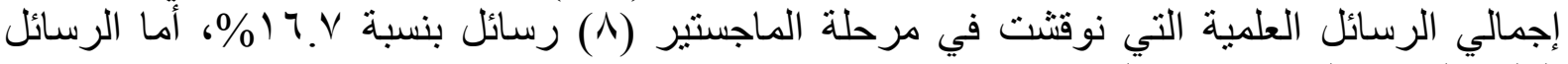

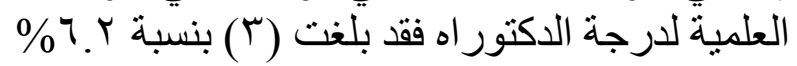

* ملحق ( ) قائمة بالرسائل العلمية والخطط البحثية لارجتي (ماجستير - ودكتوراه) ، والبحوث التي نشرث بمجلة البحوث

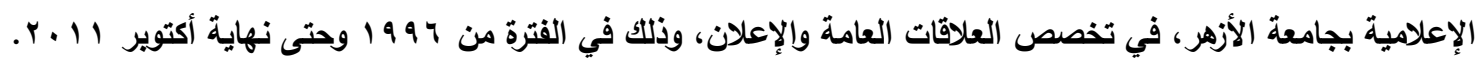




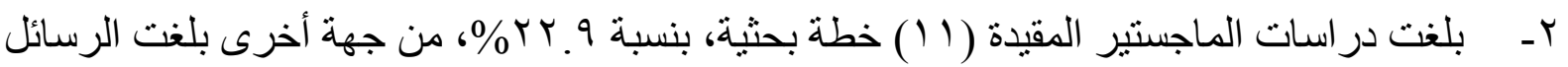

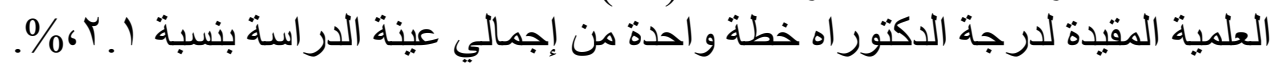

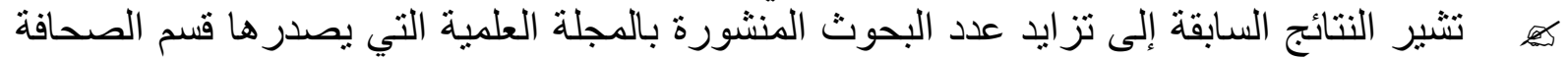

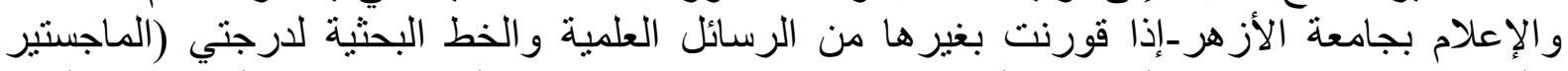

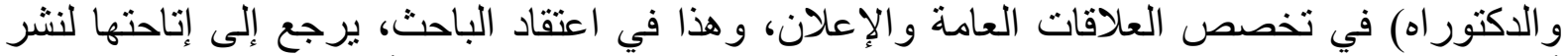

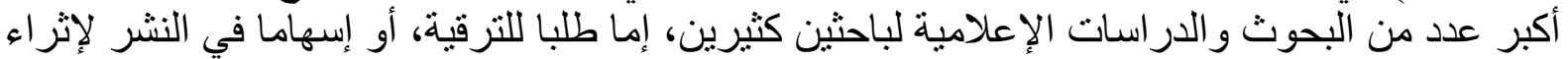

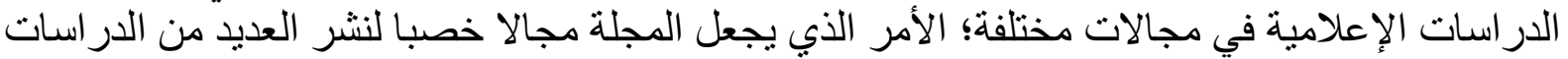
و البحوث كما تقوم به كثير من المجلات العلمية في العديد من الكليات و الأقسام العلدية المختلفة.

\section{عرض نتائج الدراسة التحليلية :}

أولاً: مدى تناول الار اسات الإعلامية_عينة البحثـ لمجالات الدراسات العلمية لتخصص العلاقات العامة والإعلان:

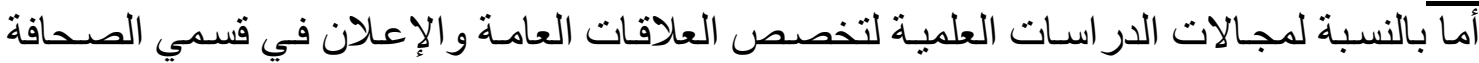

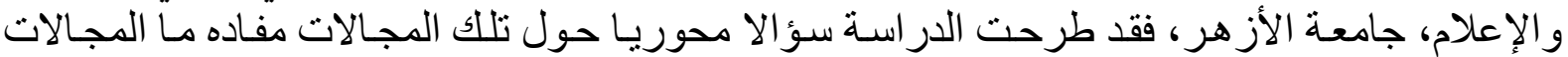

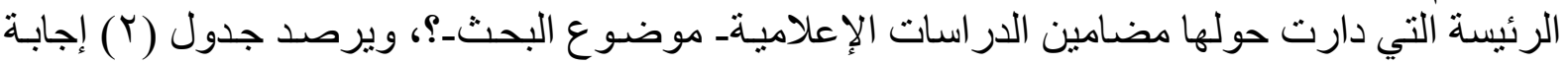

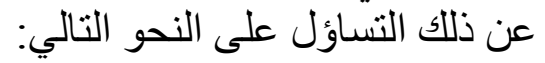

جدول (ץ) بيان بمجالات الاراسات العلمية لتخصص العلاقات العامة والإعلان

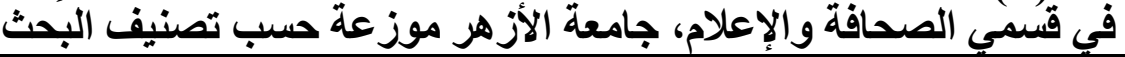

\begin{tabular}{|c|c|c|c|c|c|c|c|}
\hline \multirow[b]{2}{*}{$\%$} & \multirow[b]{2}{*}{ Total } & \multicolumn{5}{|c|}{ تصنيف البحث } & \multirow[b]{2}{*}{ المجال } \\
\hline & & لالمسجة & لالدظجة & ماجستير & دكتوراد & منشورة بمجية & \\
\hline YY. $9 \%$ & 11 & $\bar{Y}$ & $T$ & $\varepsilon$ & $T$ & $\Gamma$ & إعلام دولي \\
\hline $1 \leqslant .7 \%$ & $\bar{V}$ & T & - & - & - & 0 & علاقات عامة \\
\hline $1 \cdot .4 \%$ & 0 & 1 & - & 1 & $T$ & r & إعلان تلفزيوني \\
\hline $7.5 \%$ & $\bar{\Gamma}$ & $T$ & - & - & - & $\bar{Y}$ & اتصال سياسي \\
\hline $7.5 \%$ & $r$ & - & - & 1 & - & $r$ & إعلان صحفي \\
\hline$\varepsilon . r \%$ & $r$ & 1 & - & - & - & $T$ & الإعلام الايني \\
\hline ६. Y\% & $\bar{r}$ & - & - & - & - & $\bar{Y}$ & تسويق سياسي \\
\hline$\varepsilon . \% \%$ & $r$ & 1 & - & - & - & 1 & صورة ذهنية \\
\hline$\varepsilon .4 \%$ & $r$ & - & - & - & - & r & منظمات محلية \\
\hline r. $1 \%$ & 1 & - & - & 1 & - & - & دعاية و تسويق \\
\hline$r .1 \%$ & 1 & - & - & - & - & 1 & استخدامات الإنترنت \\
\hline
\end{tabular}




\begin{tabular}{|c|c|c|c|c|c|c|c|}
\hline$Y .1 \%$ & 1 & - & - & 1 & - & - & إنتاج مواد إعلامية \\
\hline$r .1 \%$ & 1 & - & - & - & - & 1 & الإعلام و القضايا \\
\hline$Y .1 \%$ & $T$ & 1 & - & - & - & - & الاتصال و الإعلان \\
\hline Y.1\% & 1 & 1 & - & - & - & - & العلاقات العامة و \\
\hline Y.1\% & 1 & - & - & - & - & 1 & والإعلام الغزبي الغرب \\
\hline r.1\% & 1 & - & - & - & 1 & - & إعلان صحفيوني و \\
\hline Y. $.1 \%$ & $T$ & $T$ & - & - & - & - & تسويق اجتماعي \\
\hline Y.1\% & 1 & - & - & - & - & 1 & العلاقة بين الإعلام و \\
\hline r. $1 \%$ & 1 & - & - & - & - & 1 & العلاقة بين الإعلام الإخرى \\
\hline \multirow{2}{*}{$1 \ldots \%$} & \multirow{2}{*}{$\varepsilon \wedge$} & 11 & 1 & $\Lambda$ & $r$ & ro & Total \\
\hline & & YY.q\% & $Y .1 \%$ & $17.2 \%$ & $7.4 \%$ & or. $1 \%$ & $\%$ \\
\hline
\end{tabular}

\section{وترصد بيانات جدول (r) عدة مؤشرات منها:}

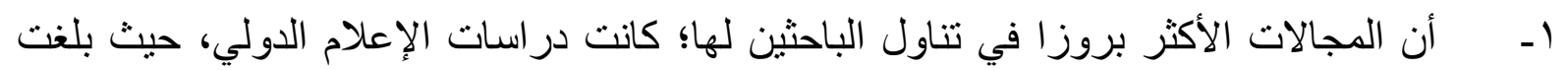

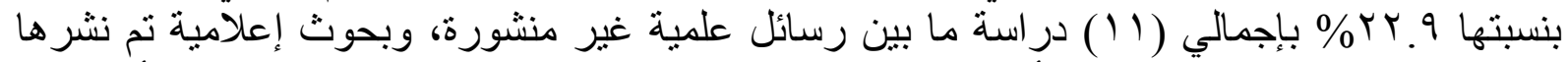
بمجلة البحوث الإعلامية بجامعة الأزهر ها وخطط مسجلة بمرحلتي الماجستير و الدكتور اه، ومن أمثلة تلك فئك

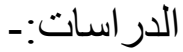

• اتجاهات الطلاب الأمريكيين نحو العرب ودور الاتصال الشخصي في تكوين تلك الاتجاهات.

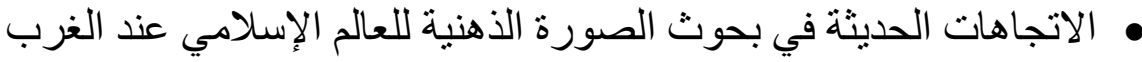

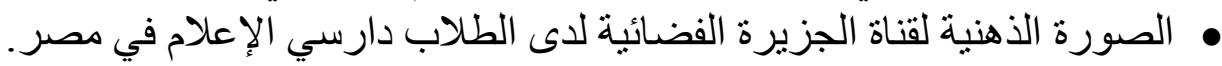

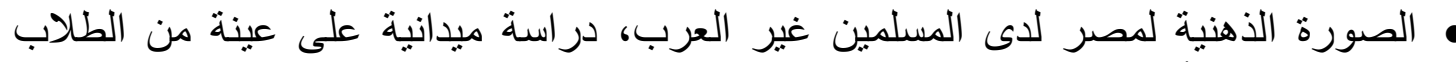

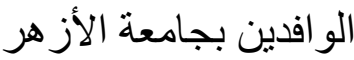
العوامل المؤثرة في تثكيل صورة الولايات المتحدة لدى قادة الرأي الدينيين بعد أحداث

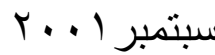
تأثير الفضائيات الموجهة بالعربية في تشكيل الصورة الذهنية عن الدول الأوروبية لدى المصريين، در اسة تطبيقية • دور الاتصال في تكوين الصورة الذهنية عن الولايات المتحدة الأمريكية لدى الثباب اليمني

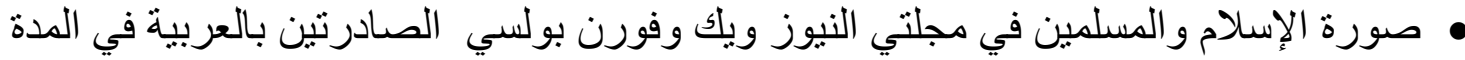
• صورة المنظمات الدولية لدى الجمهور وقادة الر أي اليمنيين 


\section{• صورة المنظمات العربية في الصحف الالكترونية الإندونيسية، در اسة تحليلية

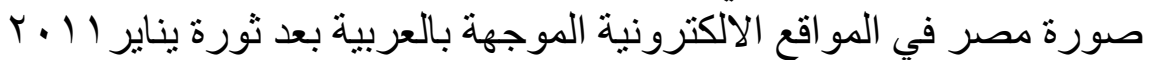

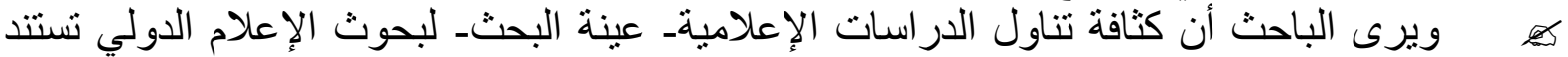

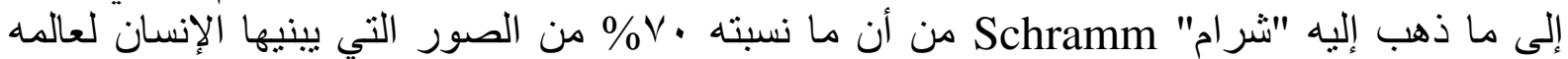

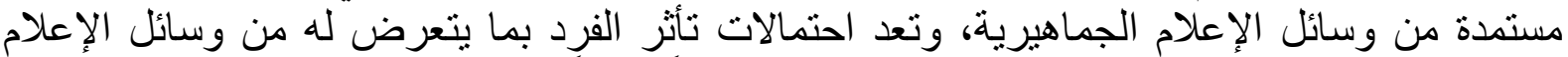

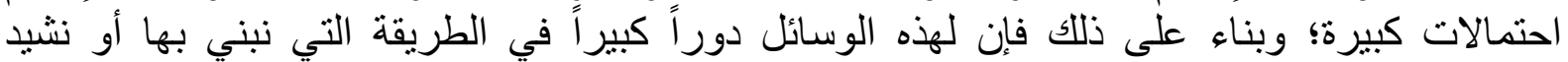

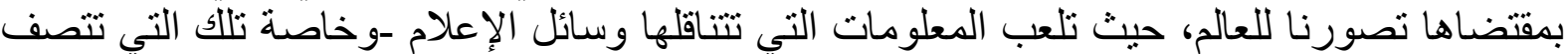

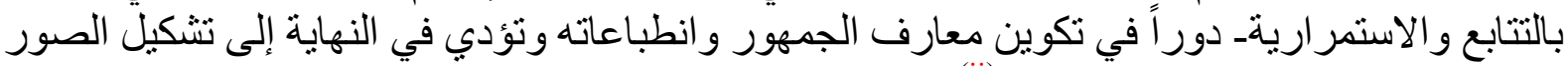

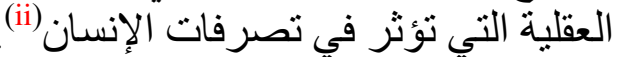

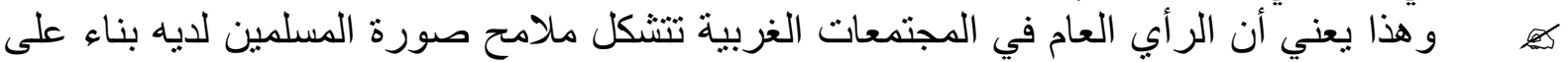

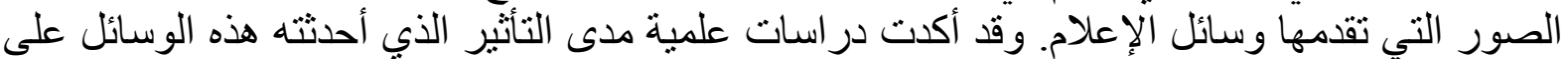

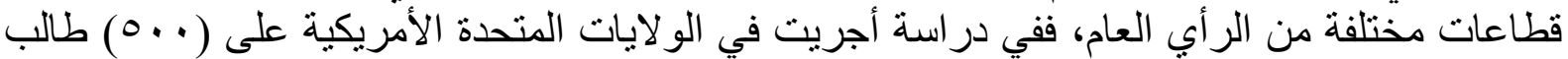

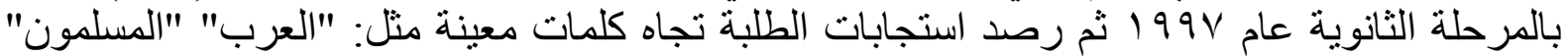

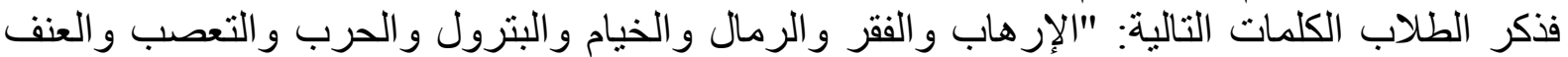

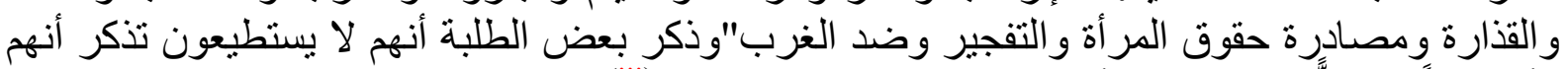

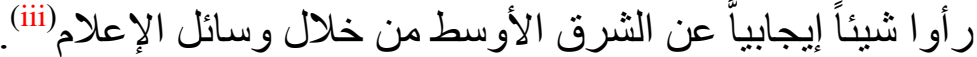

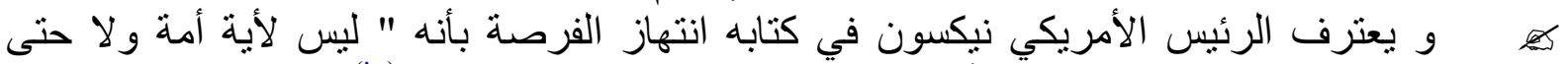

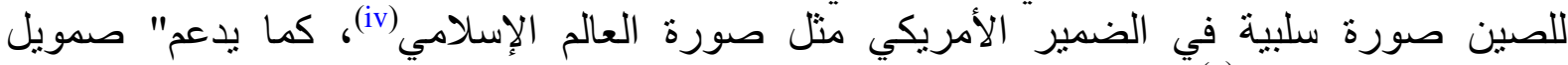

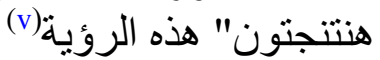
كهيج

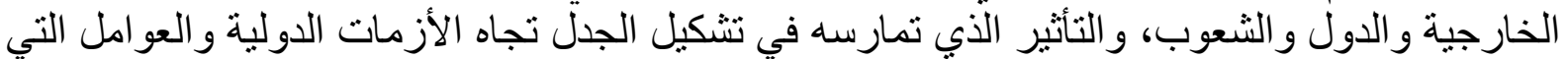

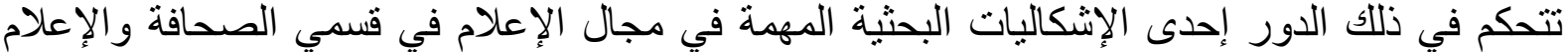

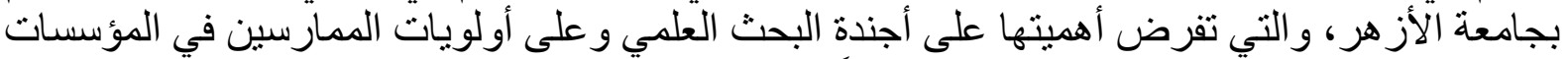

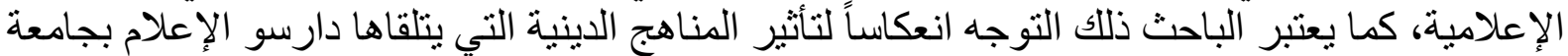

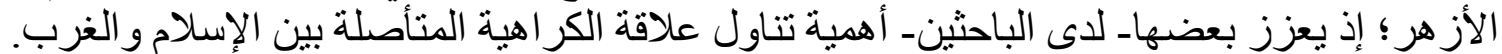

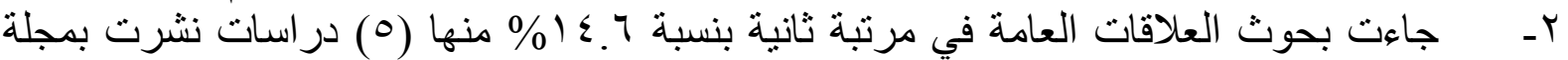

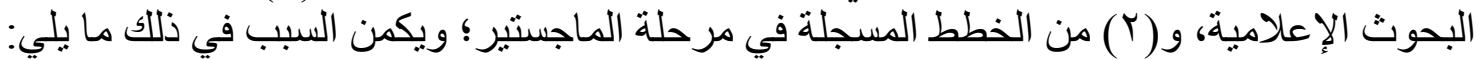

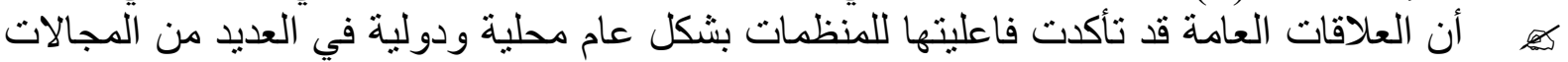

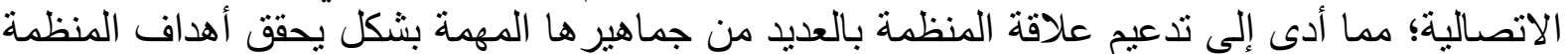

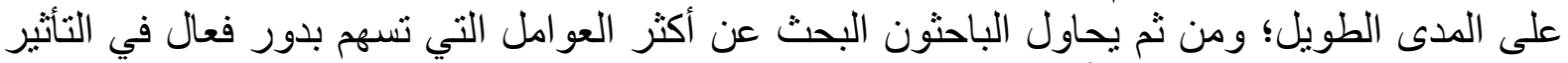

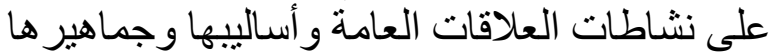

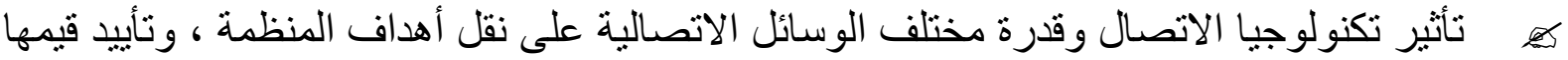

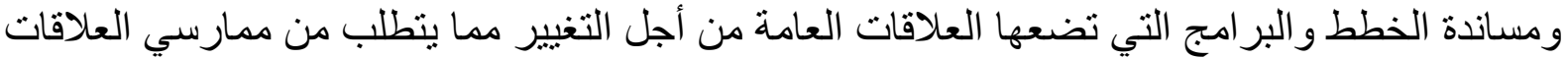

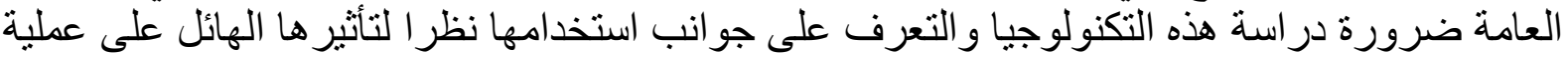

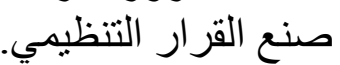

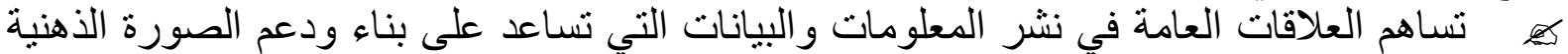

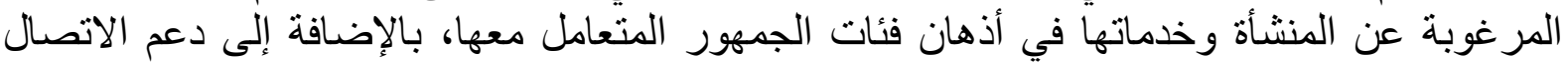

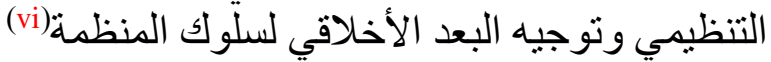




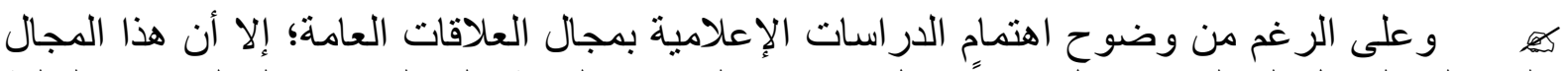

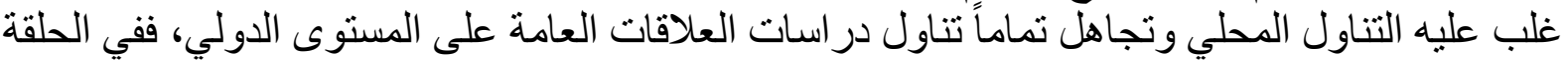

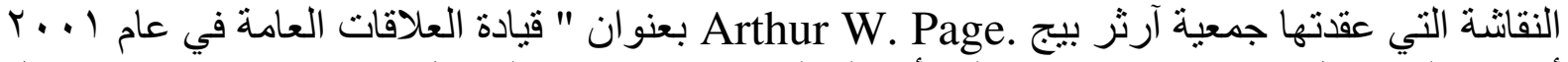

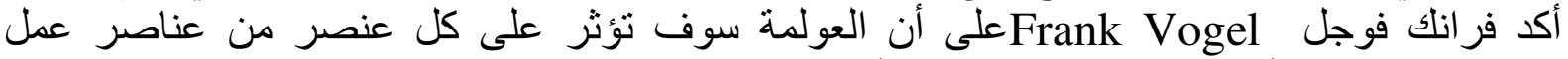

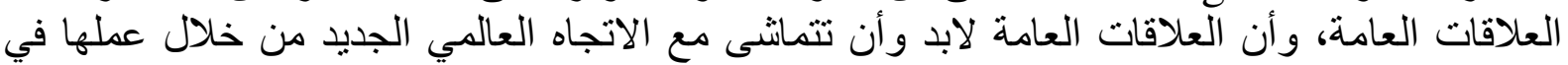

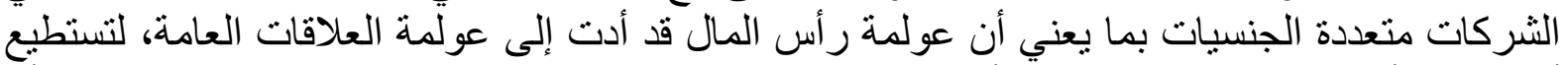

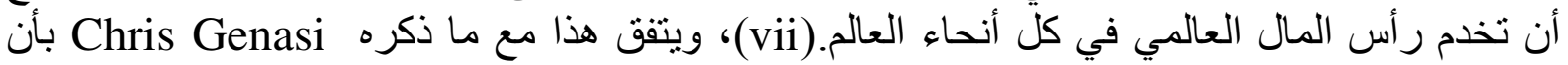

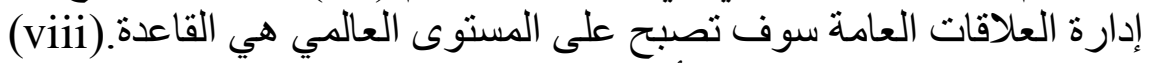

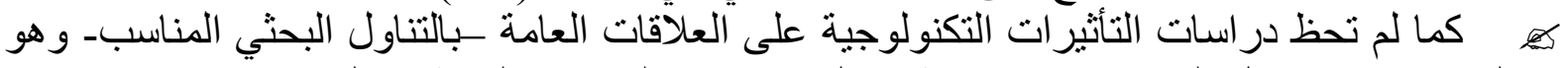

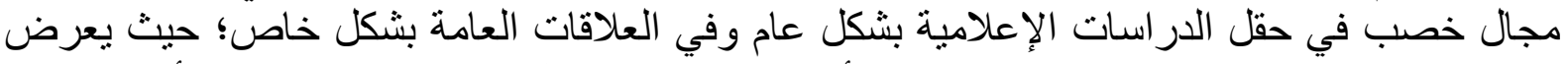

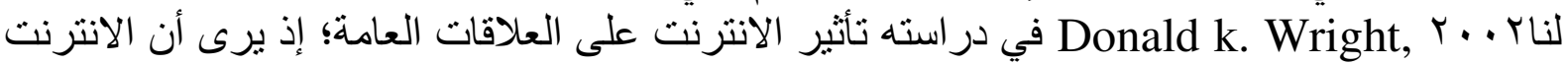

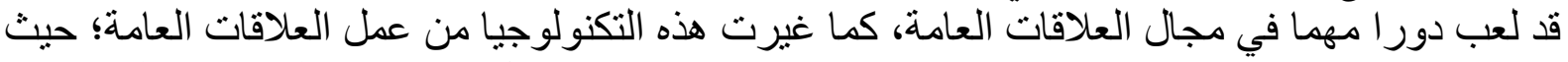

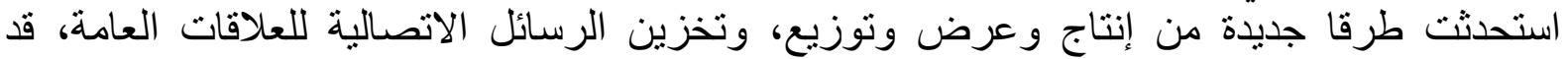

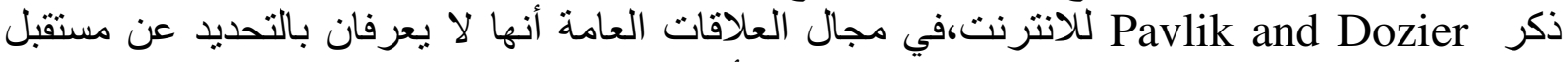

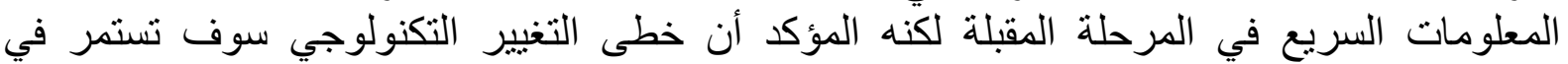

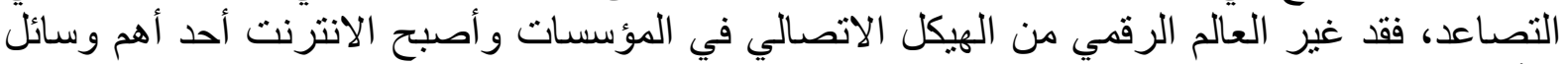

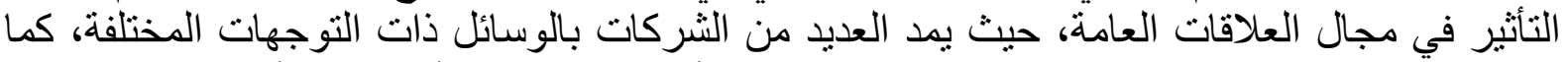

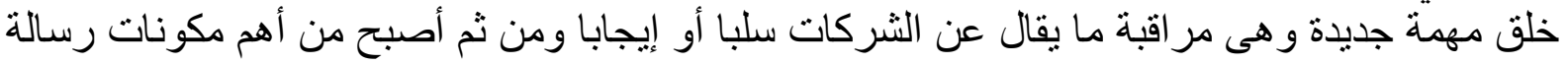

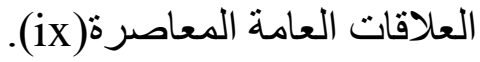

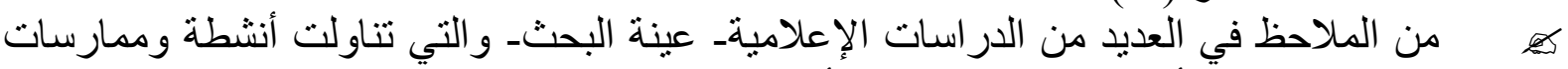

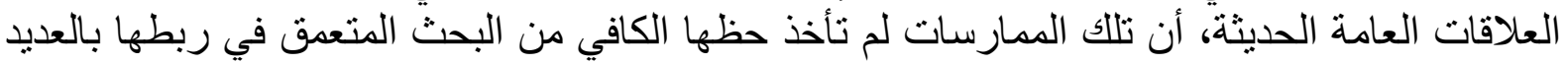

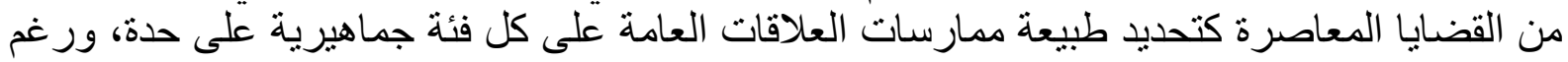

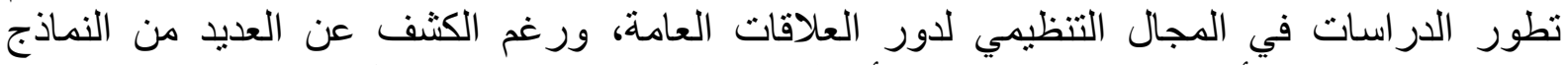

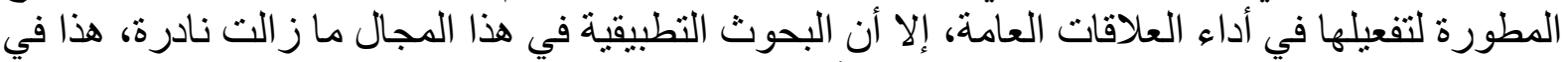

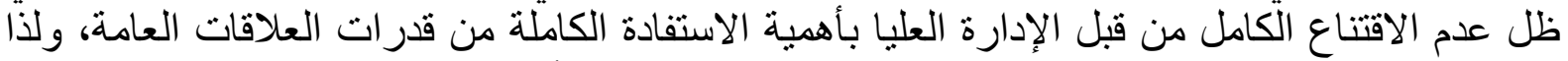

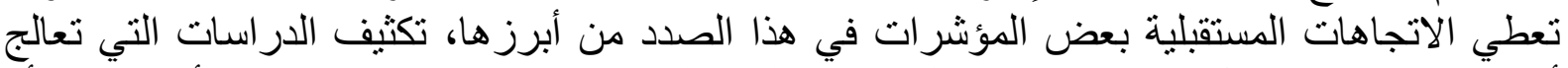

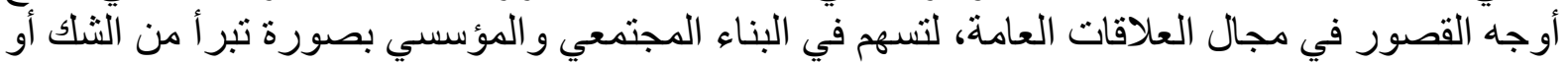

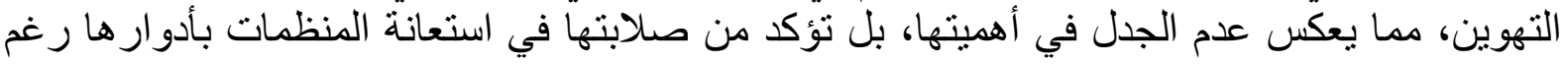
تو اصل المتغير ات المحلية و الدولية.

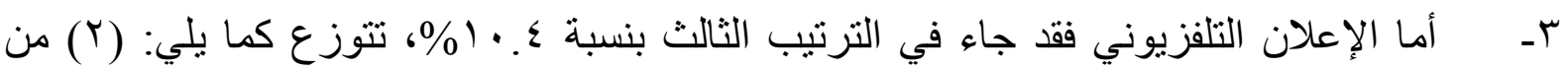

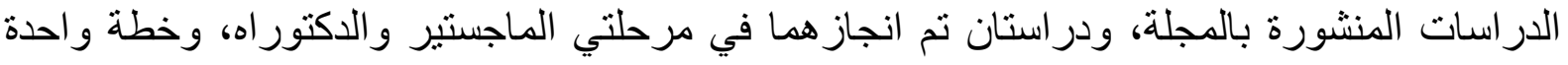
مسجلة في درجة الماجستير.

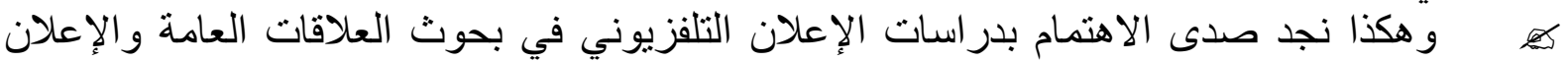

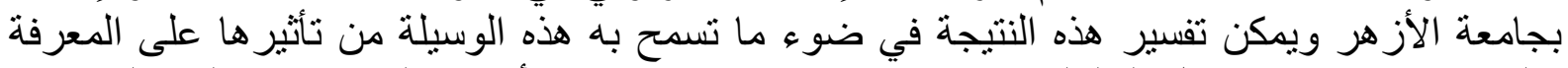

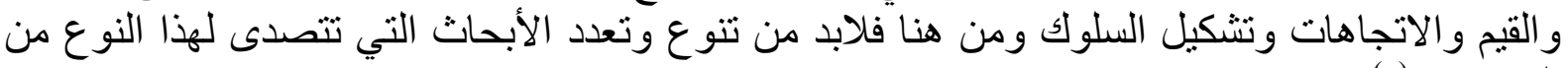

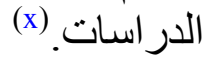

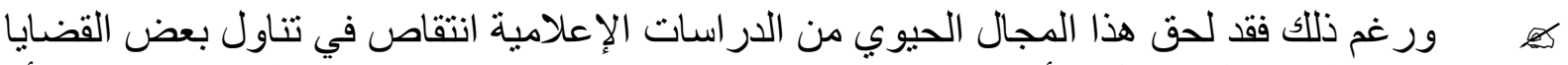

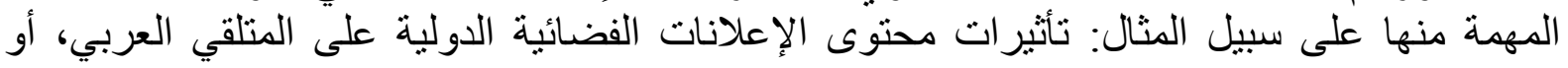




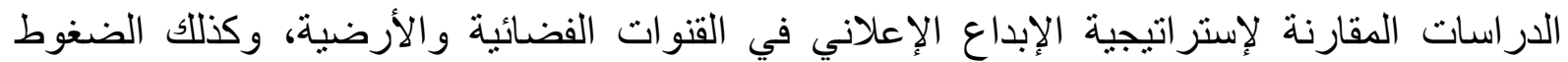

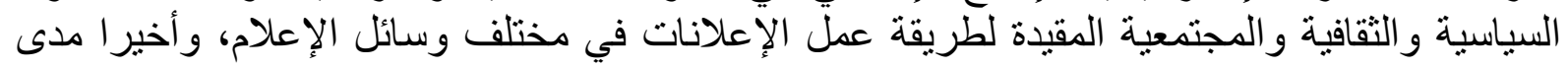
تو افق استر اتيجيات الإعلان المحلي مع استر اتيجيات الإعلان الدولي في ظل استخدام الوسائط الإعلانية غير التقليدية.

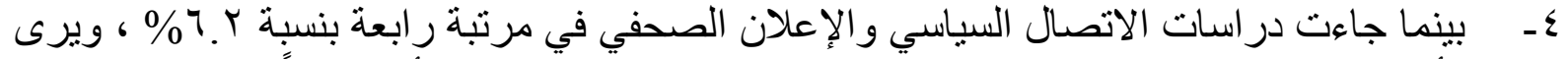

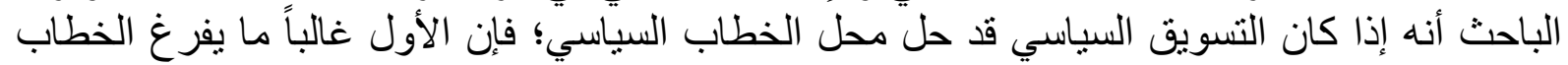

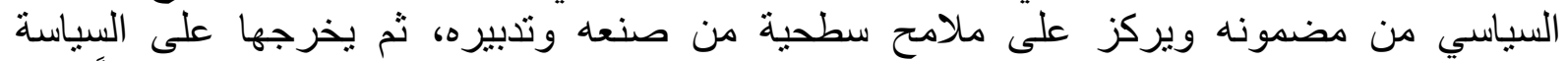

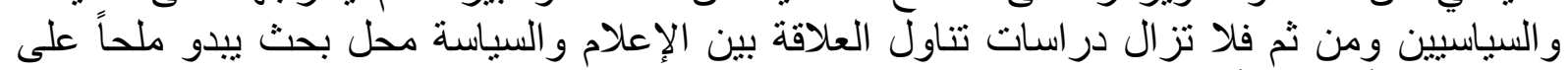
الساحة الآن أكثر من أي وقت مضن مضنى.

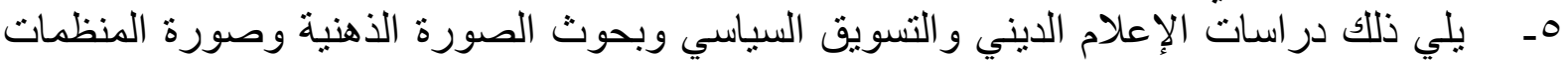

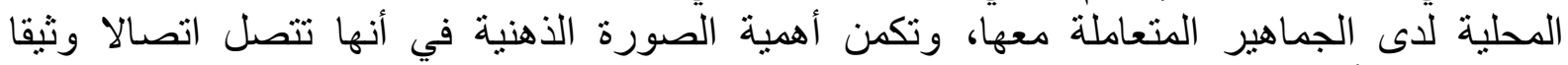

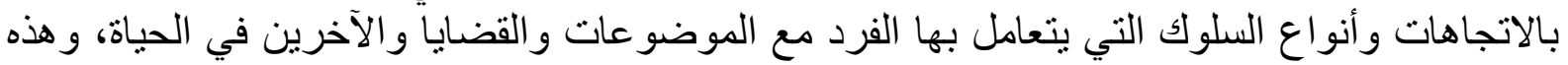

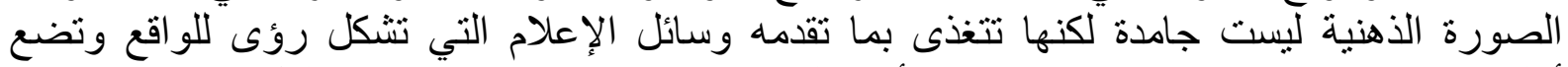

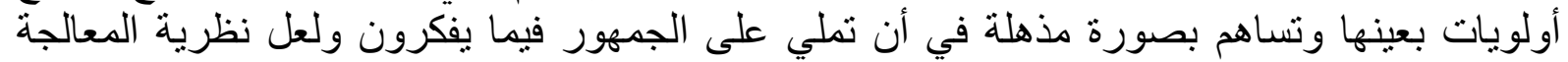

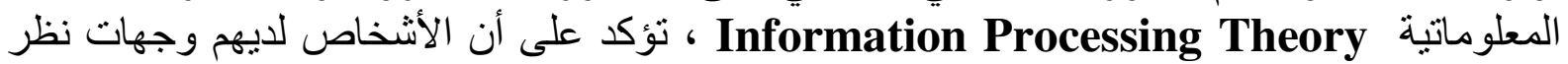

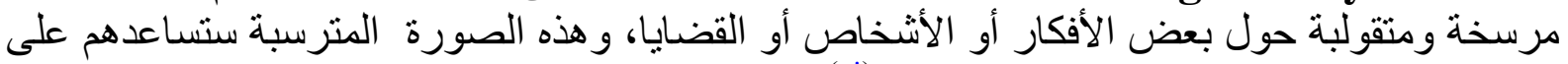

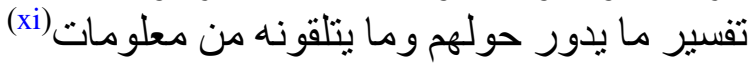

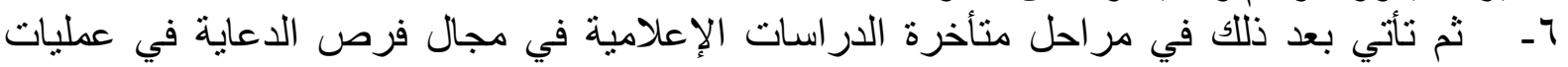

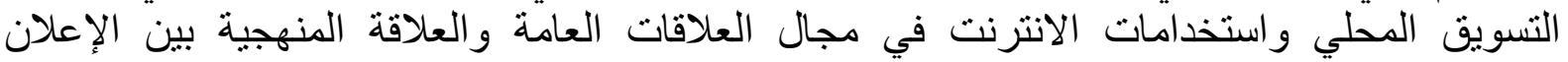

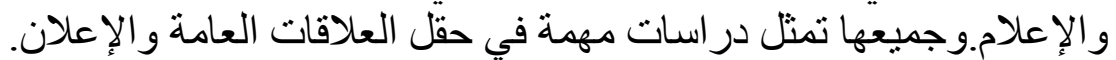

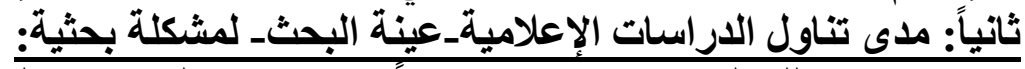

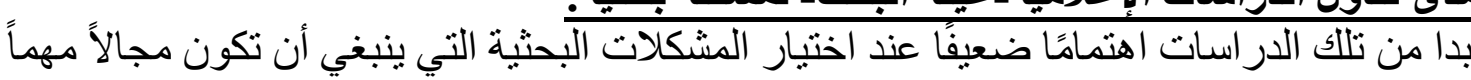

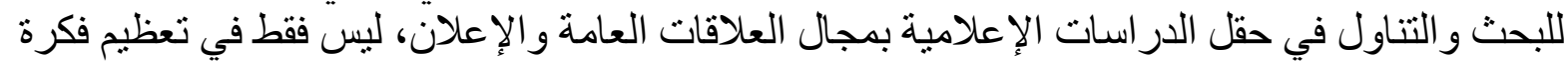

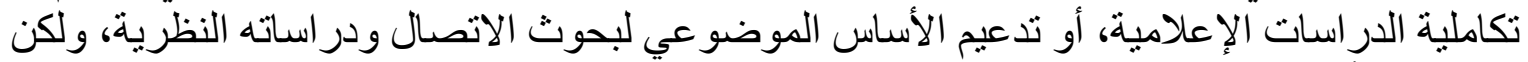

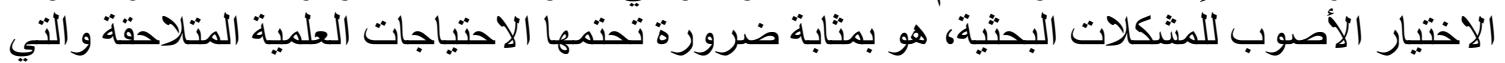

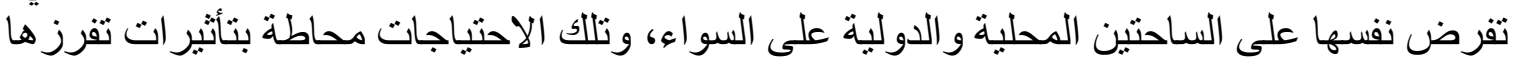

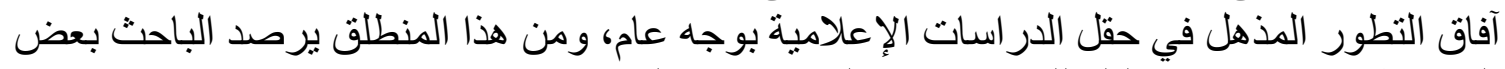

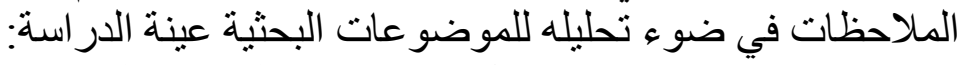

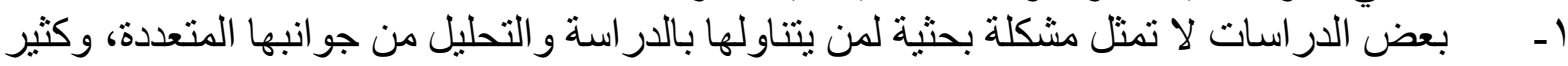

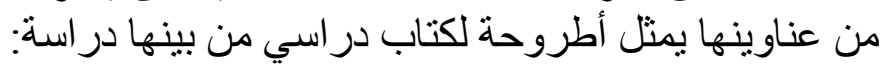

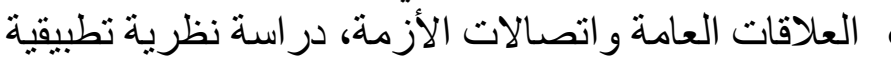

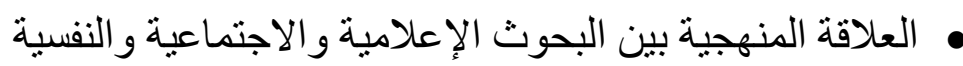

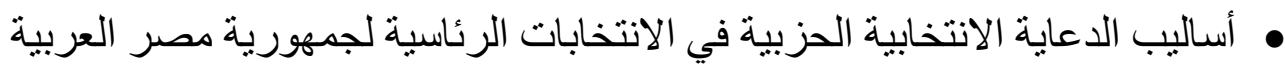

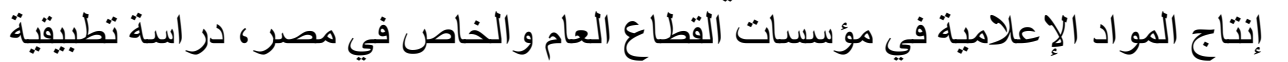

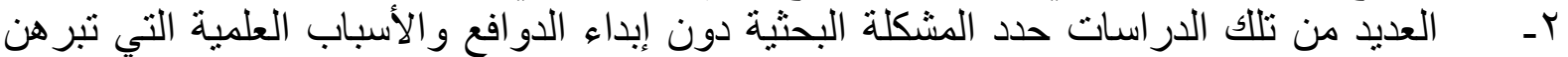

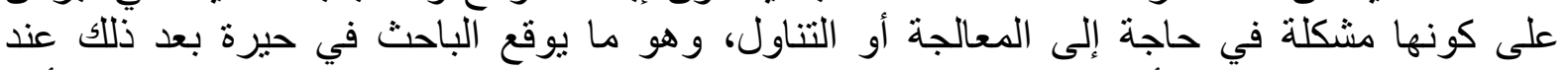

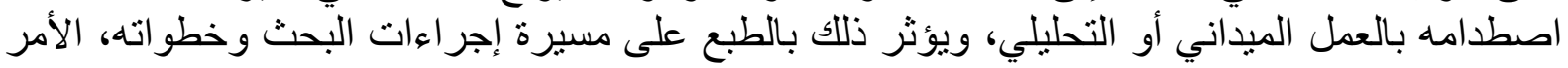


الذي يتنافى مع بديهيات البحث العلمي، بل ويعكس عدم اقتناع الباحث بوجود مشكلة بحثية تحظى بلهى

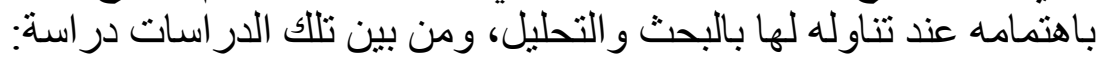

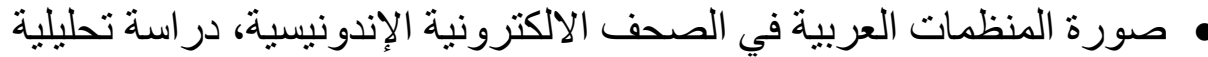

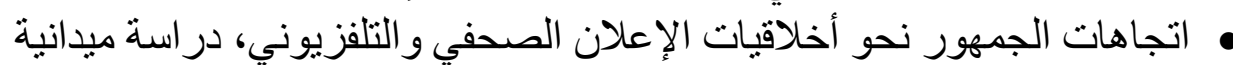

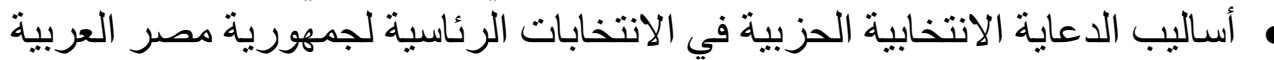

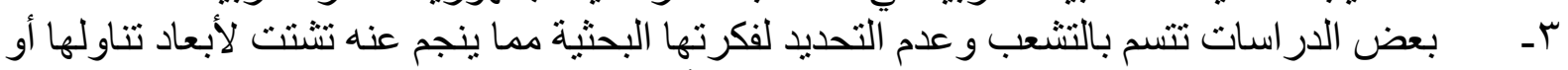

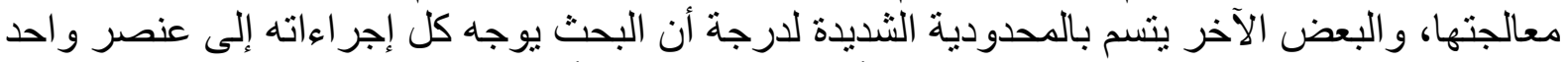

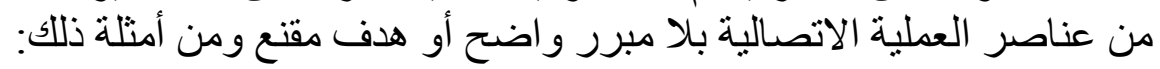

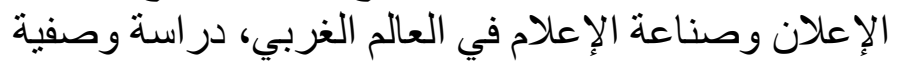

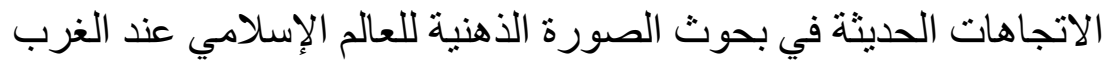

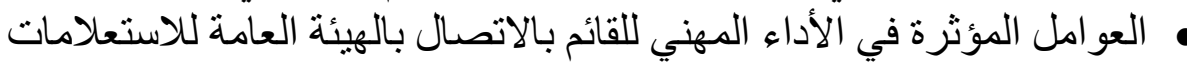

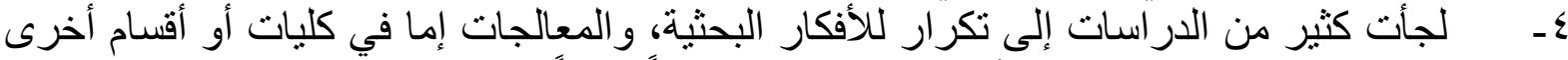

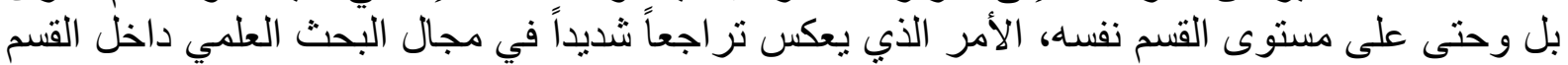

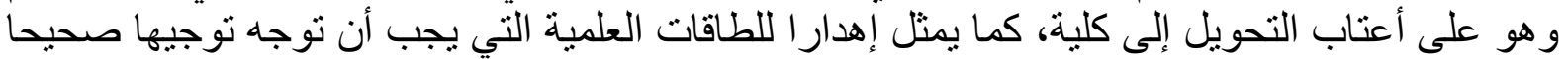

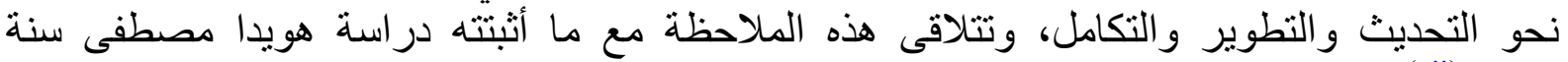
(xii) 1997

\section{ثالثاً: مدى تتاول الدراسات الإعلامية_عينة البحثـ لعناصر العملية الاتصالية:}

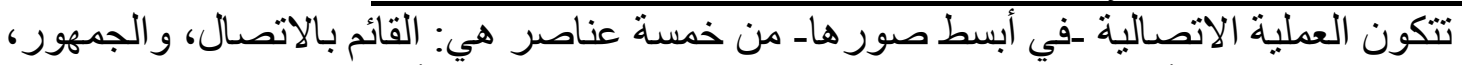

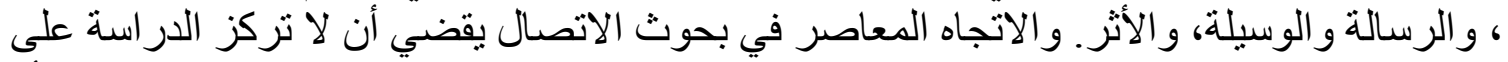

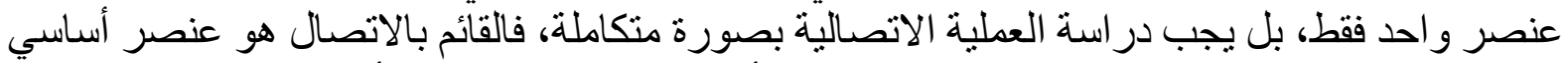
من عناصر العملية الاتصالية إذ يعتبر وحدة التحليل الأصغر في الإجابة على الأسئلة الخاصة بلئة بمسئولية الإلية

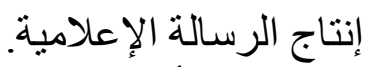
ومنذ أواخر الستينات من القرن العشرين و هنالك اهتمام متز ايد عن القوى التي تشكل الدور الذئي

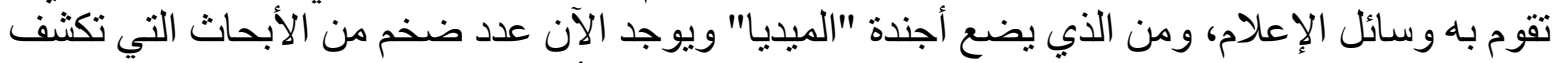

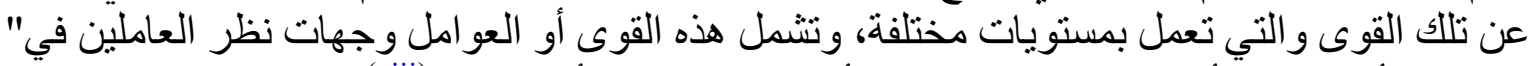

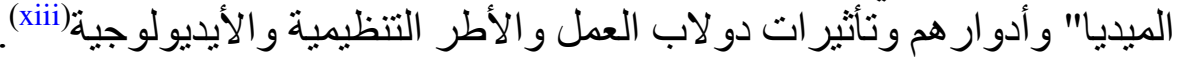

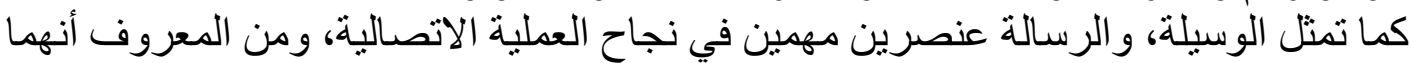

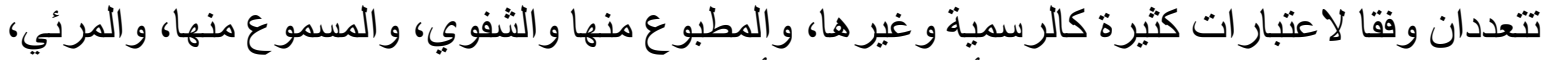

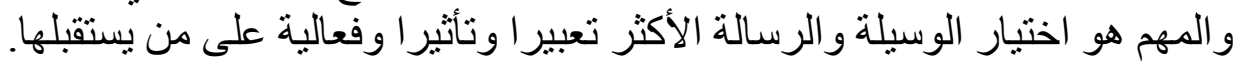

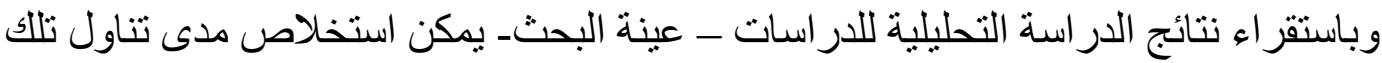

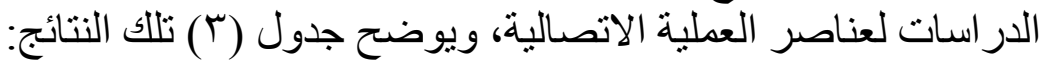


جدول (ّ) بيان بمدى تناول الدراسات - عينة البحثـ لعناصر العملية الاتصالية موزعة حسب تصنيف البحث البث لفن

\begin{tabular}{|c|c|c|c|c|c|c|c|}
\hline \multirow{3}{*}{$\%$} & \multirow{3}{*}{ Total } & \multicolumn{5}{|c|}{ تصنيف البحث } & \multirow{3}{*}{ عناصر العملية } \\
\hline & & خطة & خطة & , & ، سيائذا & بحوث & \\
\hline & & الماجستيرة & الدكتوجة اه & ئي & توراه ت ت ت ت & بمجلة & \\
\hline 0 ०ะ.Y\% & rq & $\varepsilon$ & - & 0 & $\bar{r}$ & 10 & جمهور ققط \\
\hline$r \cdot . \Lambda \%$ & 1. & $\bar{r}$ & - & 1 & - & $\bar{v}$ & رسالة ققط \\
\hline $1 \wedge . \wedge \%$ & 9 & 0 & 1 & $\bar{r}$ & - & $T$ & جمهور و رسالة \\
\hline$\varepsilon . \uparrow \%$ & r & - & - & - & - & r & لم يبين الاتصاصلية العملية \\
\hline r. $\%$ & 1 & - & - & - & 1 & - & كل عناصر العملية \\
\hline \multirow{2}{*}{$1 \ldots \%$} & \multirow{2}{*}{$\varepsilon \wedge$} & 11 & 1 & $\Lambda$ & $\mu$ & ro & Total \\
\hline & & rY. $9 \%$ & Y.1\% & $17.8 \%$ & $7.5 \%$ & or. $1 \%$ & $\%$ \\
\hline
\end{tabular}

ومن واقع الحصر الثامل لاراسات وبحوث العلاقات العامة في قسمي الصحافة والإعلام بجامعة الأزهر

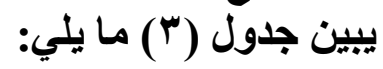

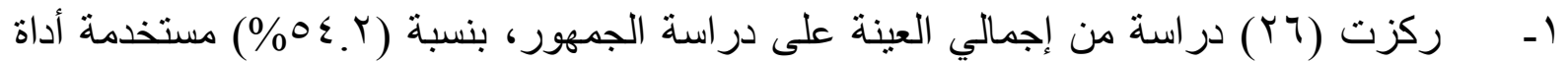

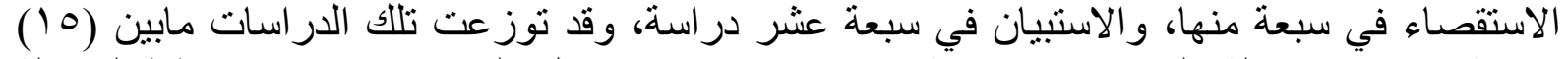

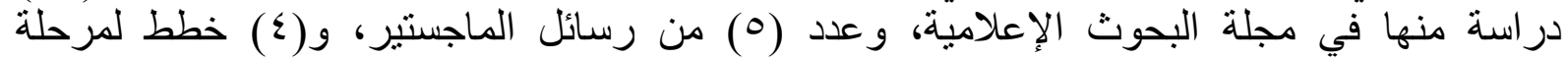
الماجستير، ودراستان من رسائل الدكتور الاه، من أمثلة تلكاتك الدراسات:

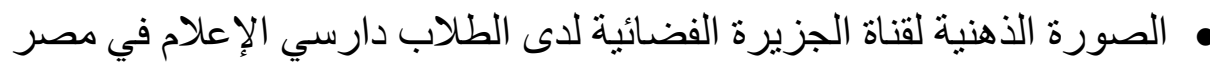

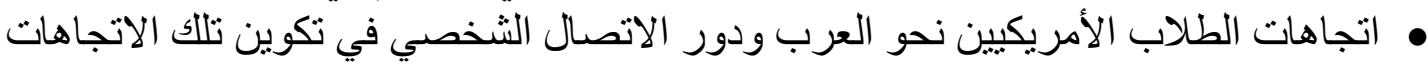

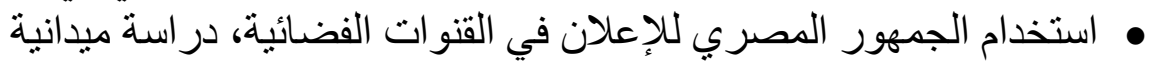

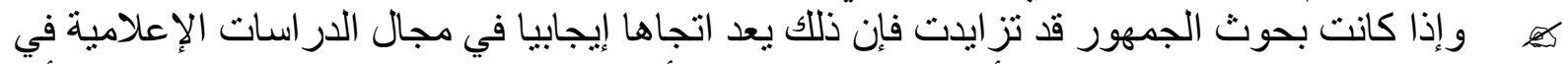

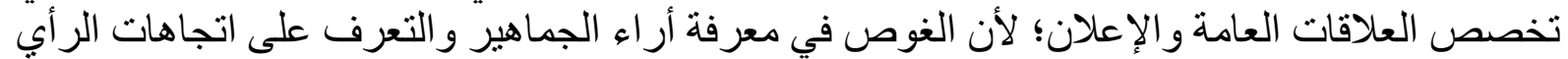

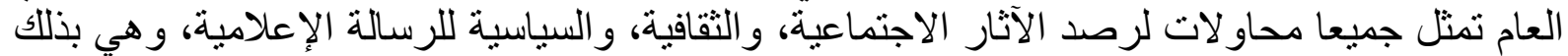

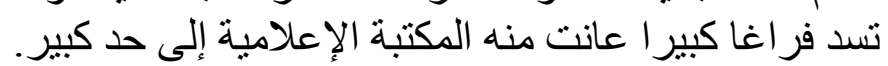

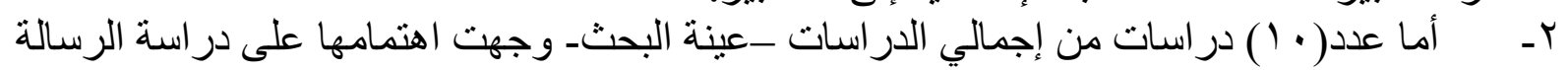

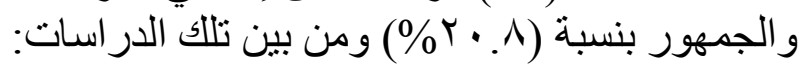

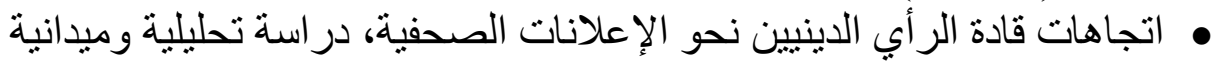

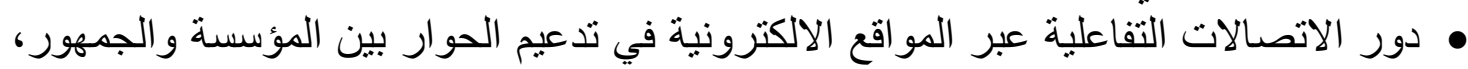




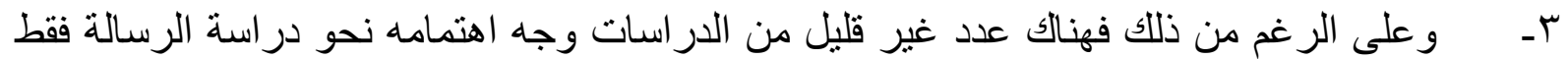

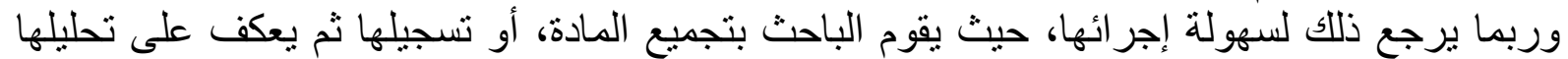

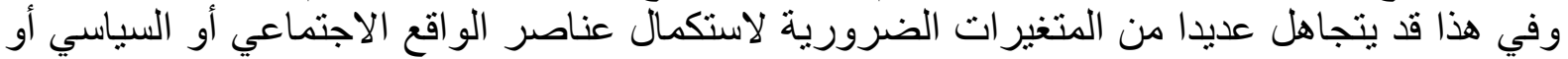

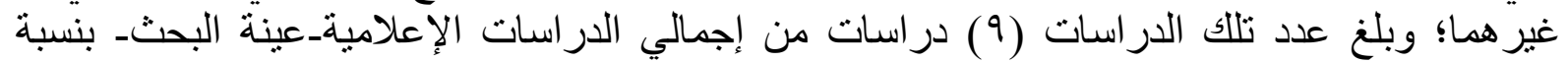

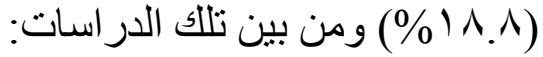

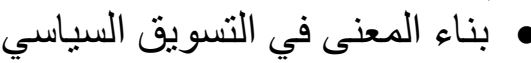

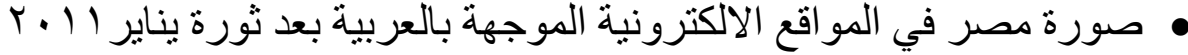

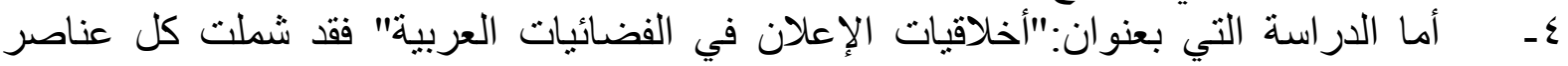

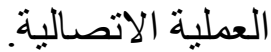
๑ـ بينما لم تبين دراستان مجال اهتمامهما نحو عناصر العملية الاتصالية و وهما بعنوان:

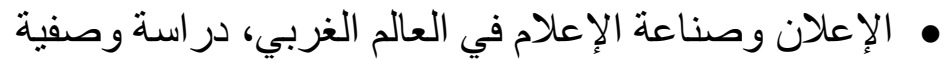

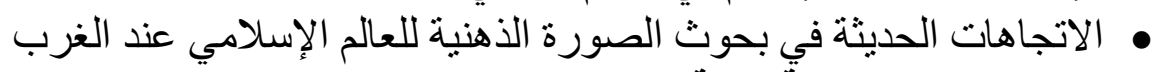

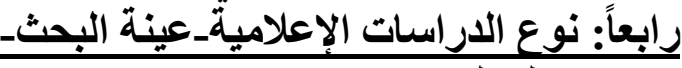

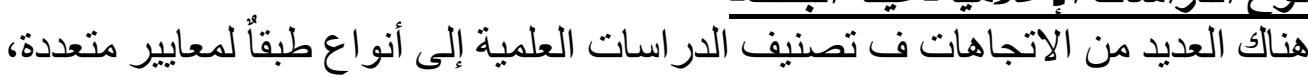

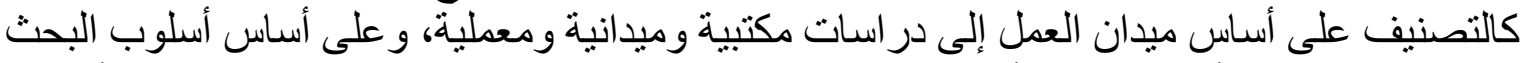

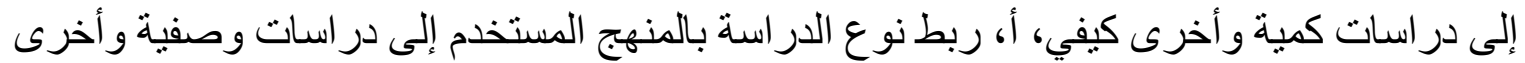

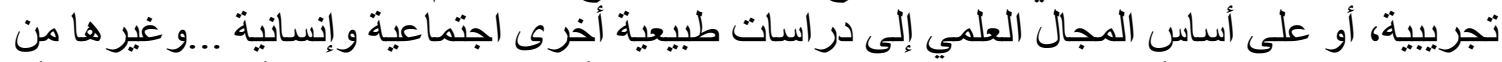

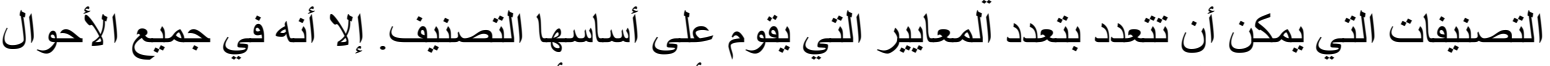

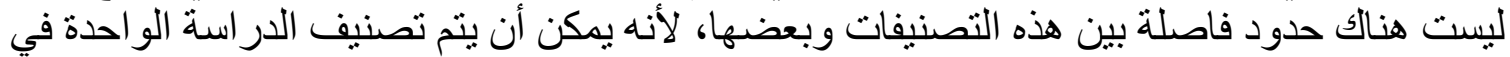

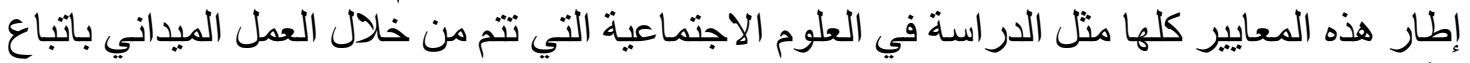

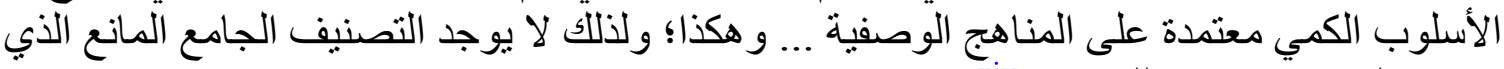

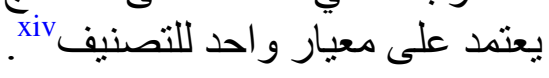

جدول ( ) يبين نوع البحوث التي تنتمي إليها الاراسات الإعلامية_عينة البحثـ-

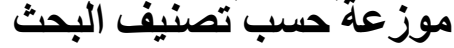

\begin{tabular}{|c|c|c|c|c|c|c|c|}
\hline \multirow{3}{*}{$\%$} & \multirow{3}{*}{ Total } & \multicolumn{5}{|c|}{ تصنيف البحث } & \multirow{3}{*}{ نوع البحث } \\
\hline & & خطة مسجلة & خطة مسجلة & رسائل | رسائ & رسائل & منشورة & \\
\hline & & الماجستير & الدكتوراه & & & علمية & \\
\hline \multirow{2}{*}{$9 \Gamma . \wedge \%$} & \multirow{2}{*}{$\leqslant 0$} & 11 & $T$ & $\Lambda$ & $\Gamma$ & $\overline{Y r}$ & \multirow{2}{*}{ وصفية } \\
\hline & & $r \leqslant . \& \%$ & Y.Y\% & $I V . \wedge \%$ & 7. $\% \%$ & $\varepsilon \wedge .9 \%$ & \\
\hline \multirow{2}{*}{$7.4 \%$} & \multirow{2}{*}{$r$} & - & - & - & - & $r$ & \multirow{2}{*}{ لم يبين } \\
\hline & & & & & & $1 \ldots . \%$ & \\
\hline \multirow{2}{*}{$1 \ldots \%$} & \multirow{2}{*}{$\varepsilon \wedge$} & 11 & 1 & $\Lambda$ & $r$ & Yo & Total \\
\hline & & Yr. $9 \%$ & r. $1 \%$ & $19.0 \%$ & $7.4 \%$ & or. $1 \%$ & $\%$ \\
\hline
\end{tabular}


عند استقرائنا لبيانات جدول (๕) )، والذي يوضح نوع البحوث التي استخدمتها الاراسات الإعلامية.

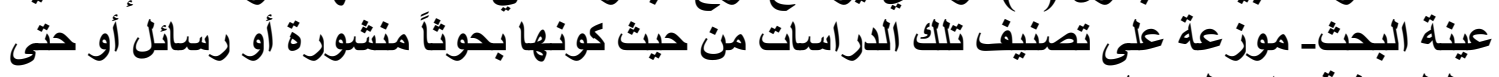

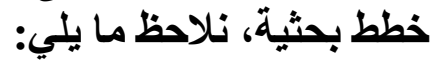

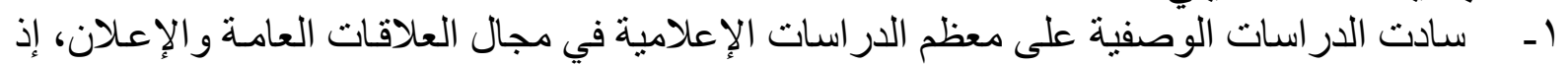

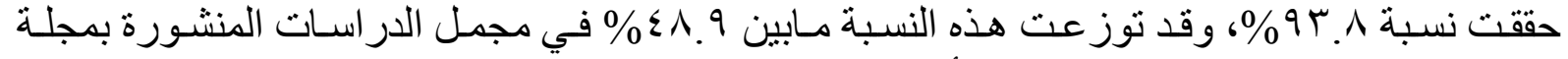

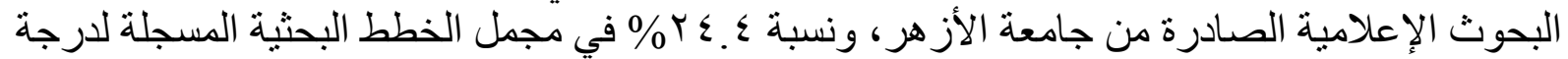

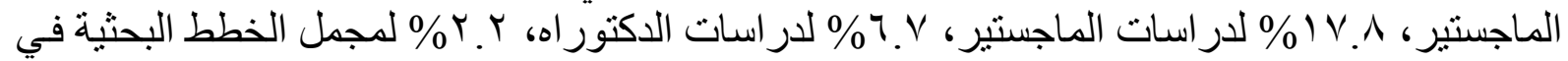

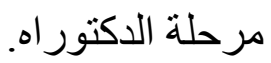

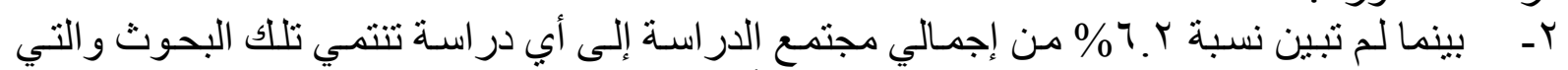

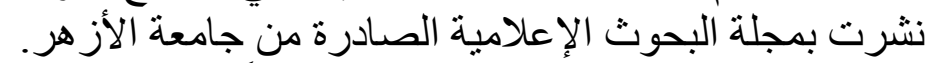

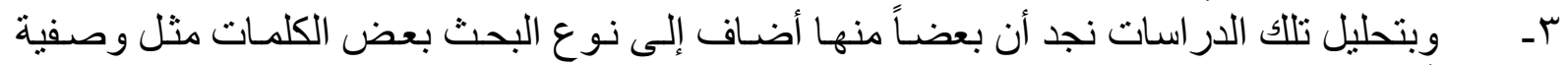

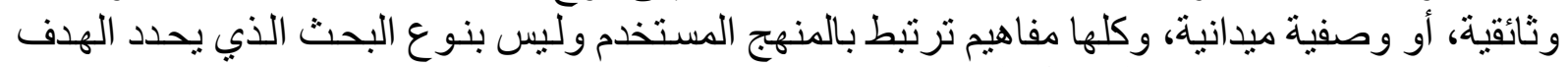
العام من در اسة الموضوع و و الوسائل المستخدمة. ومما سبق يمكن استنتاج ما يلي:

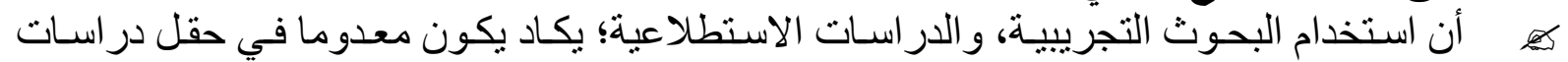

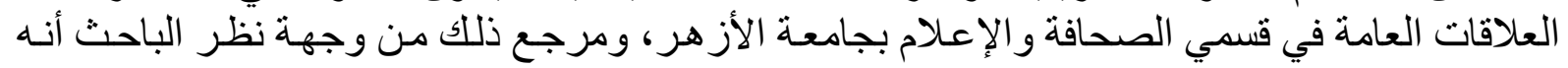

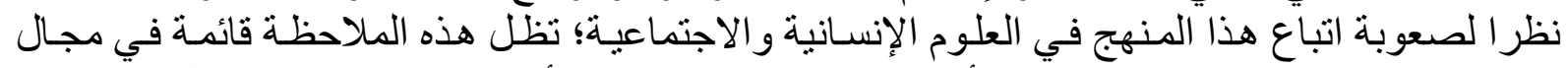

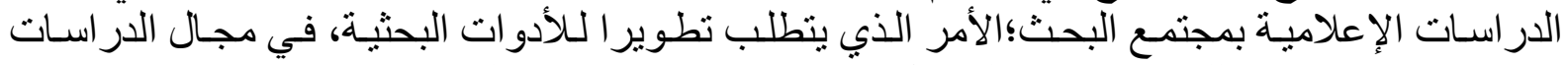

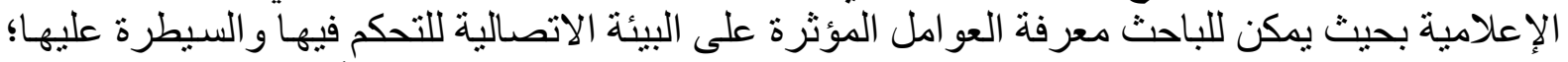

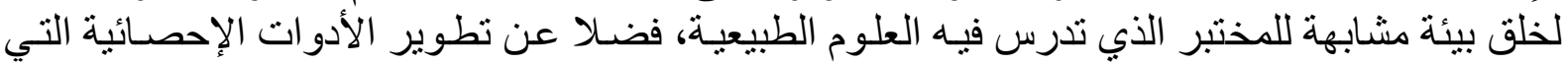

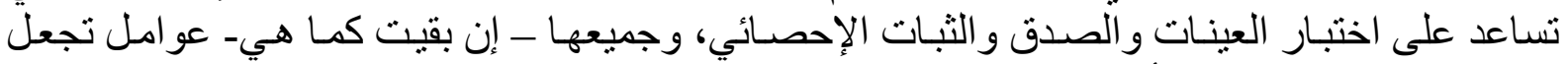
الارتكاز على هذه البحوث أمر ا محدودا.

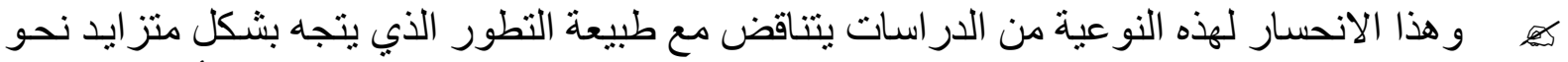

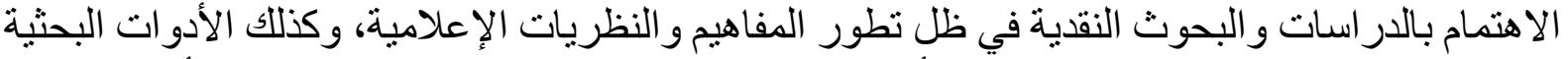

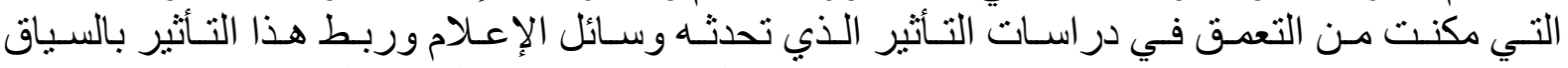

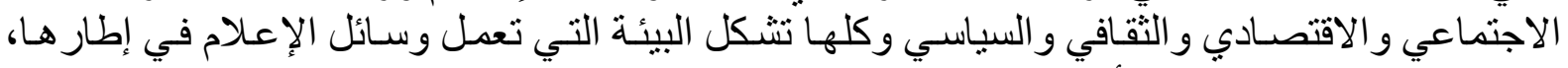

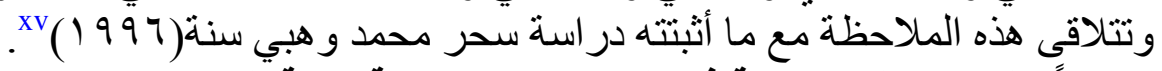

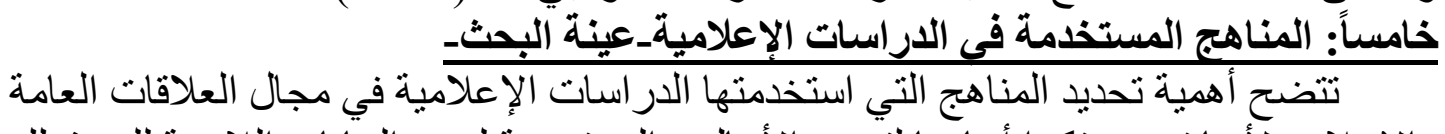

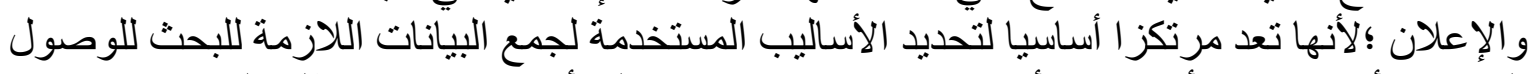

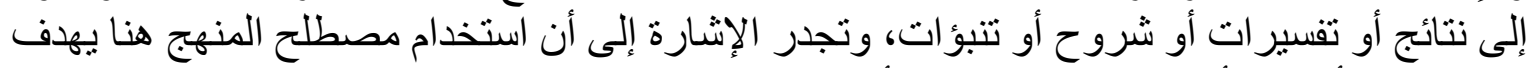

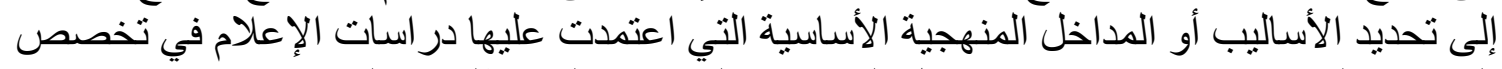

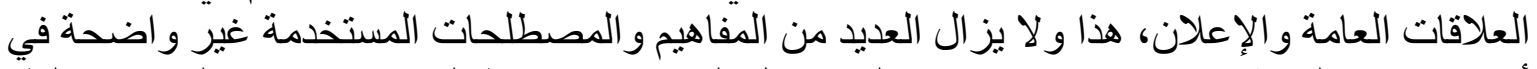

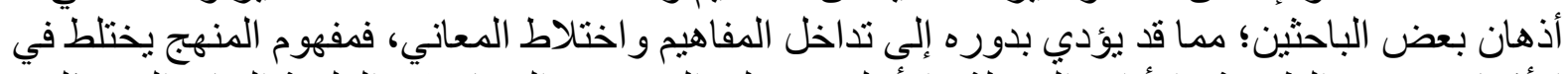

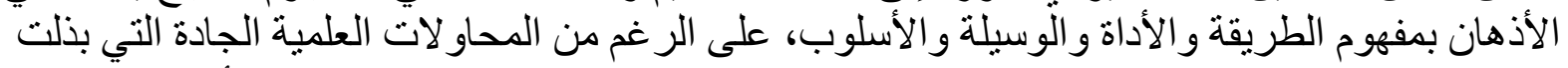

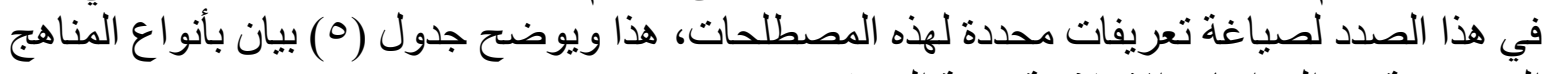

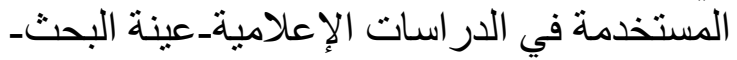


جدول (•) يبين نوع المناهج التي استخدمتها الدراسات الإعلامية_عينة البحثـموزعة حسب تصنيف البحث المثات

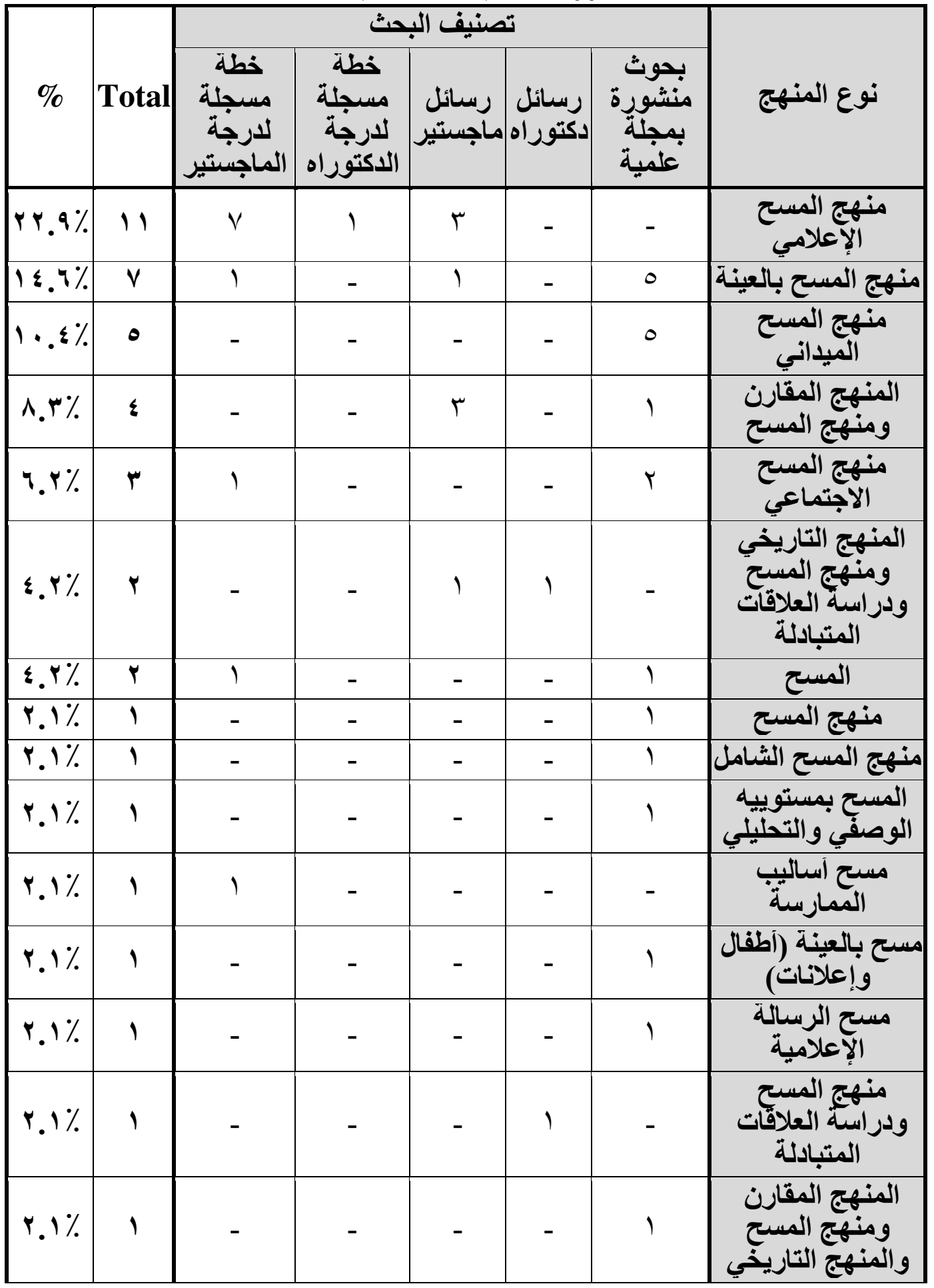




\begin{tabular}{|c|c|c|c|c|c|c|c|}
\hline r.1\% & 1 & - & - & - & 1 & - & ودراسنهج المنهاتح المقارن \\
\hline$Y .1 \%$ & 1 & - & - & - & - & 1 & تحليل المضمون \\
\hline Y.1\% & 1 & - & - & - & - & 1 & تحليل الخطاب \\
\hline Y.1\% & 1 & - & - & - & - & 1 & المنهج الوثائقي \\
\hline Y.1\% & 1 & - & - & - & - & 1 & المنهج الوصفي \\
\hline Y. $1 \%$ & 1 & - & - & - & - & 1 & لم يبين \\
\hline \multirow{2}{*}{$1 \ldots \%$} & \multirow{2}{*}{$\varepsilon \wedge$} & 11 & 1 & $\Lambda$ & $r$ & Yo & Total \\
\hline & & rr. $9 \%$ & r. $1 \%$ & $17.8 \%$ & ૫..$\%$ & or. $1 \%$ & $\%$ \\
\hline
\end{tabular}

ومن واقع بيانات جدول (•) نرى ما يلي:

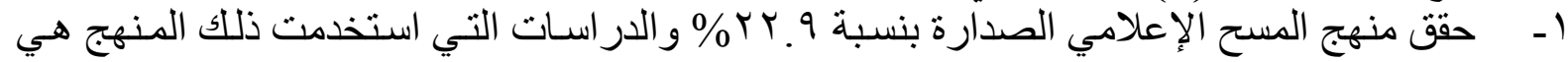

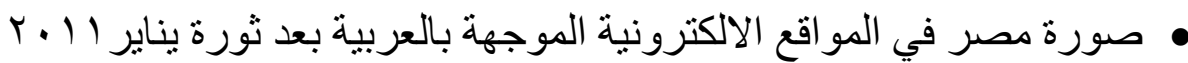

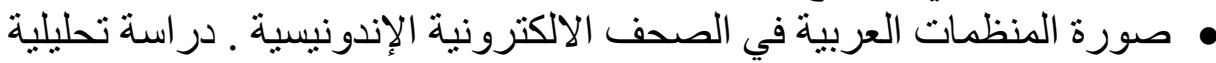

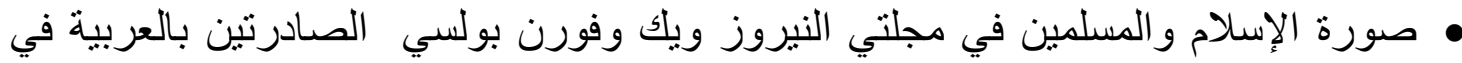

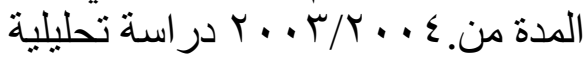
• دور حملات التسويق الاجتماعي في التوعية بمخاطر الصحة لدى طلبة المدارس، دراسة • دور الإعلانات التلفزيونية في تقديم السلوك الثرائي للشباب ، دراسة ميدانية على عينة من طلاب الجامعات المصرية • دور الاتصالات التفاعلية عبر المواقع الالكترونية في تدعيم الحوار بين المؤسسة والجمهور، در اسة تطبيقية • تأثير الفضائيات الموجهة بالعربية في تشكيل الصورة الذهنية عن الدول الأوروبية لدى المصريين، در اسة تطبيقية الماتبة • • إنتاج المو اد الإعلامية في مؤسسات القطاع العام و الخاص في مصر ـ در اسة تطبيقية

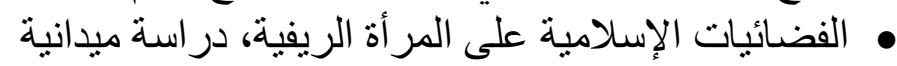

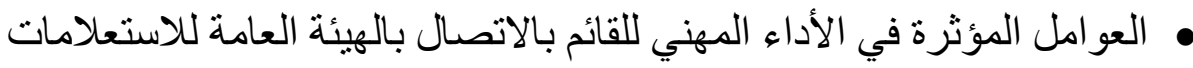

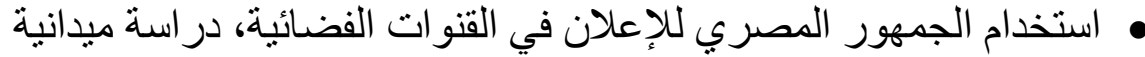

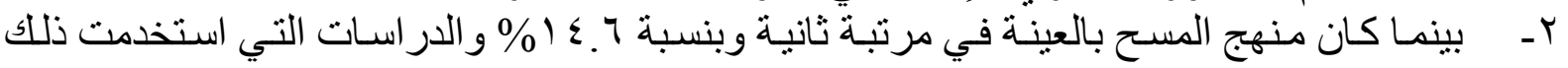

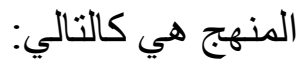
• اتجاهات الطلاب الأمريكيين نحو العرب ودور الاتصال الثخصي في تكوين تلاك الاتجاهات • احتياجات التدريب وتقييمه لدى العاملين في العلاقات العامة، دراسة على شركات مصرية التهات

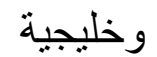
الإعلان التحريري في الصحافة المصرية 
• العلاقات العامة و اتصالات الأزمة، در اسة نظرية تطبيقية

• تقويم فاعلية المطبوعات كوسيلة اتصالية في دوائر العلاقات العامة في المؤسسات الخاصة درة نطاتة

بقطاع غزة، در اسة وصفية تحليلية

هور الاتصال في تكوين الصورة الذهنية عن الورة لايات المتحدة الأمريكية لدى الثباب اليمني

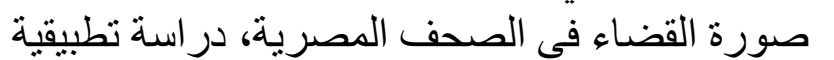

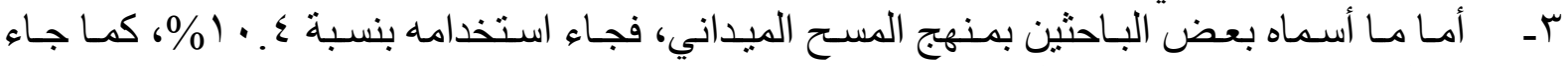

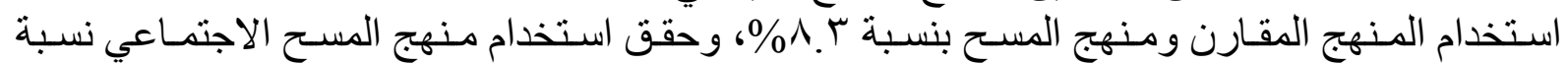

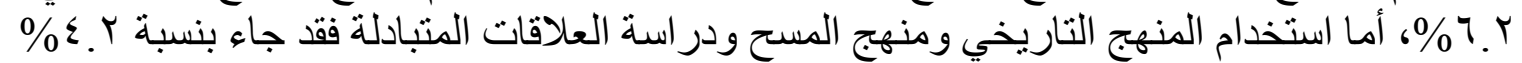

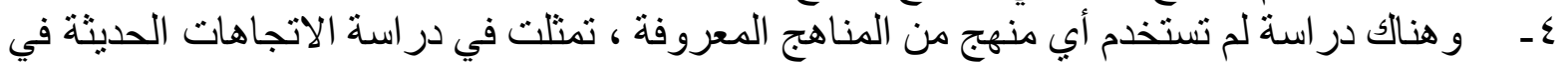

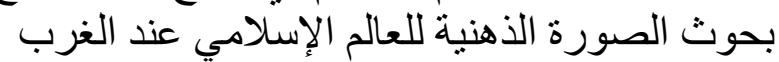

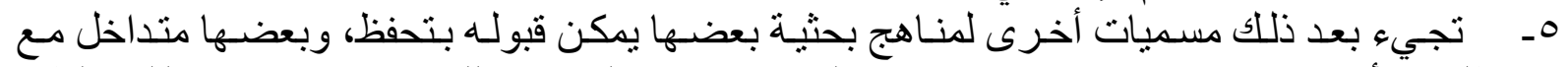

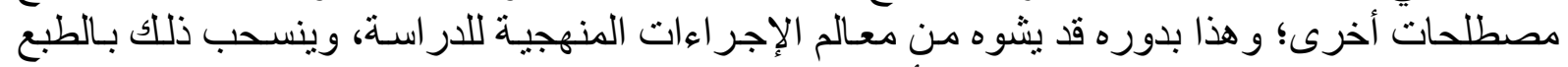

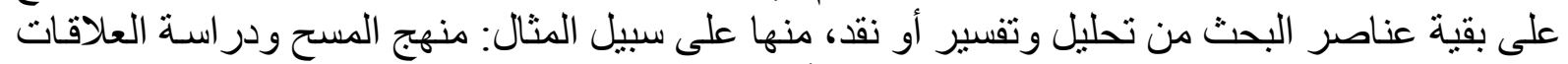

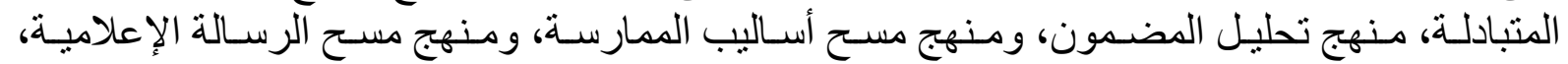

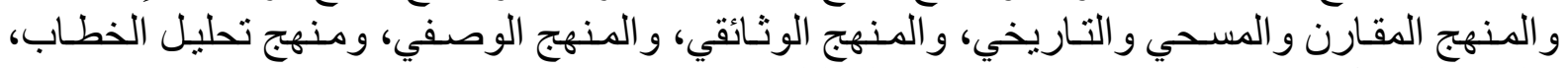

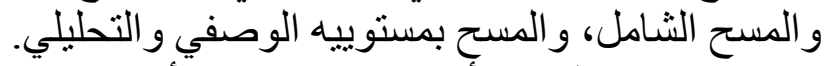

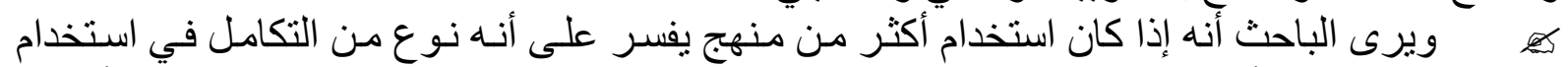

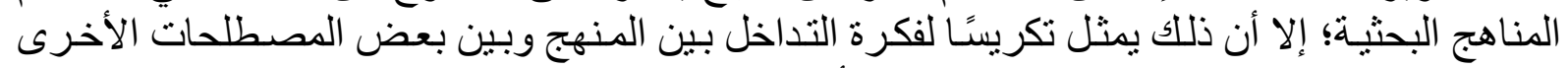

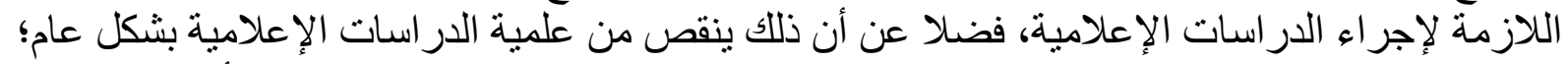

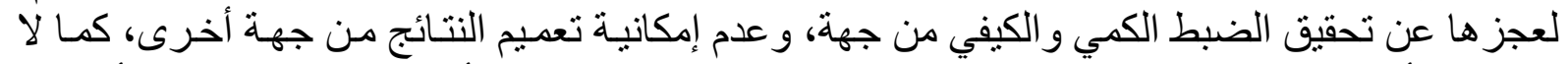

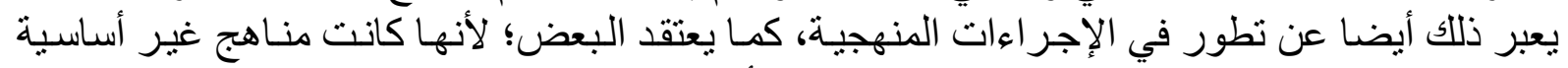

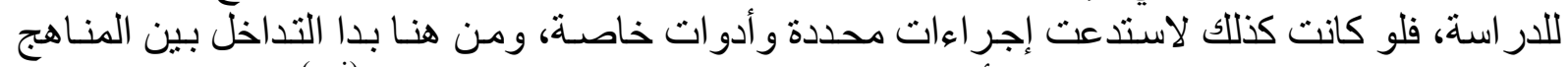

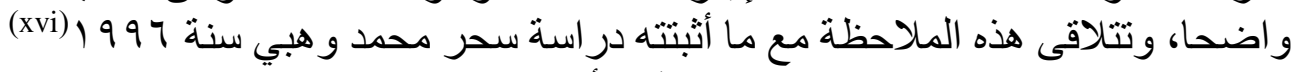

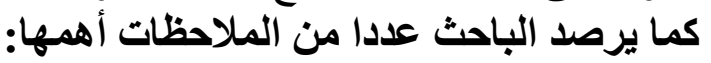

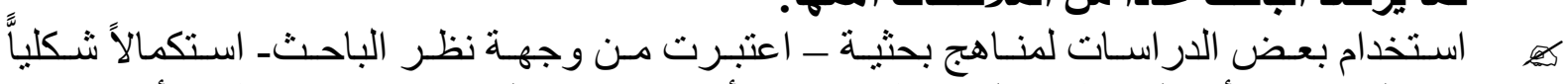

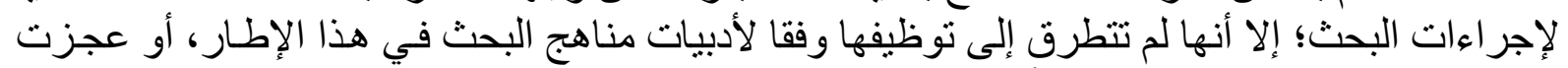

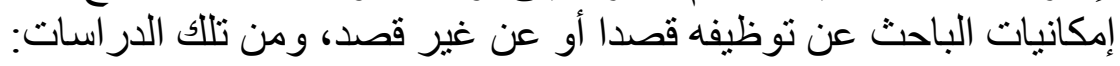

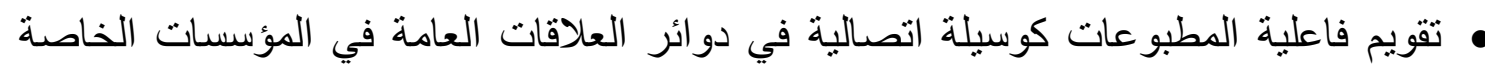
بقطاع غزة، در اسة وصفية تحليلية

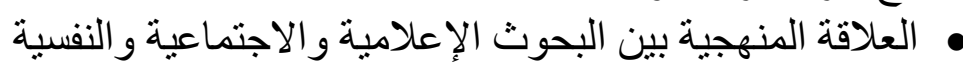

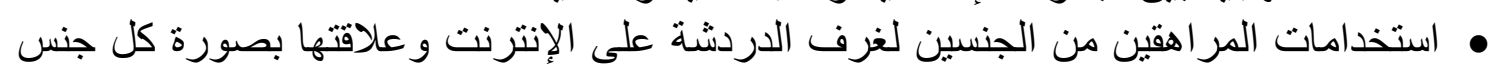
لاعى الآخر

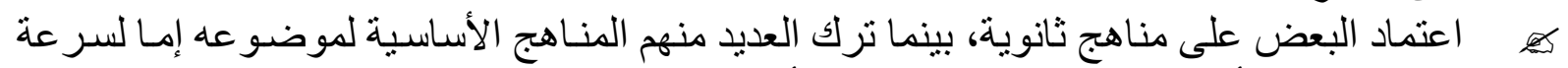

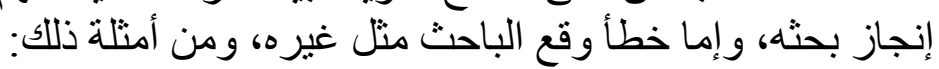
• تقويم فاعلية المطبوعات كوسيلة اتصالية في دوائر العلاقات العات العامة في المؤسسات الخاصة الخاصة بقطاع غزة، در اسة وصفية تحليلية • صورة مجلس الشعب و أعضائه لاى الإعلاميين البرلمانيين، در اسة مسحية 
الصورة الذهنية لمصر لدى المسلمين غير العرب، دراسة ميدانية على عينة من الطلاب

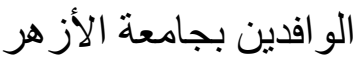

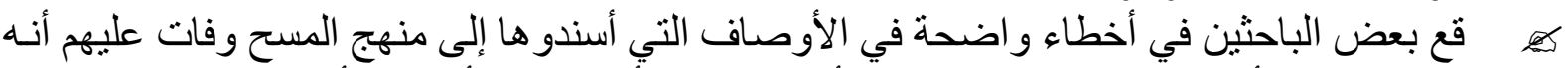

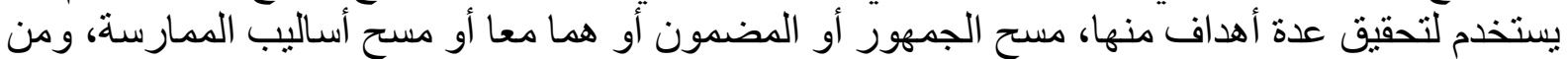

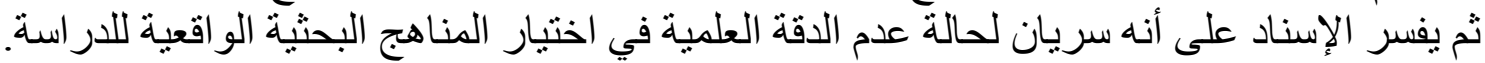

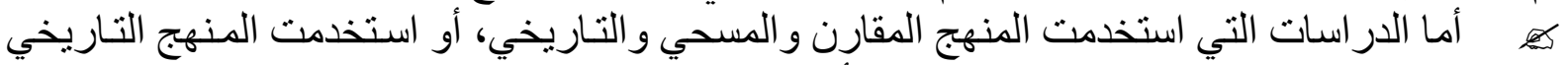

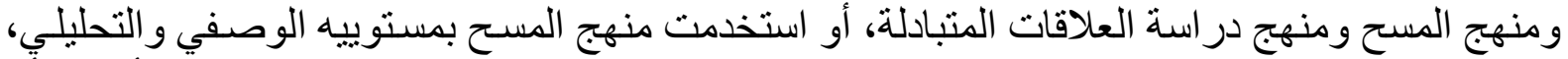

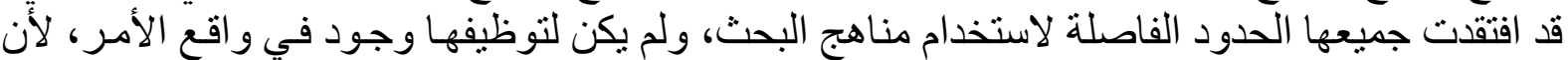

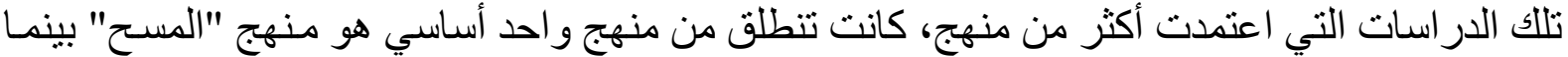

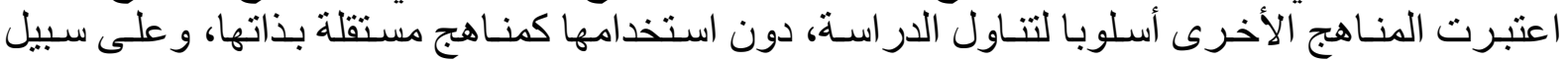

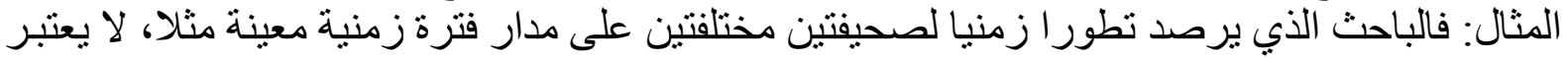

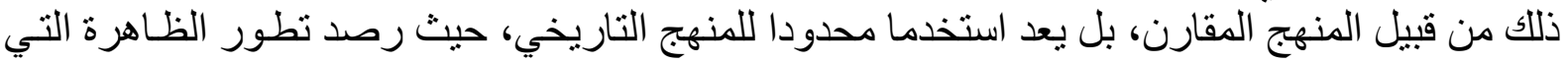
خضعت للار اسة.

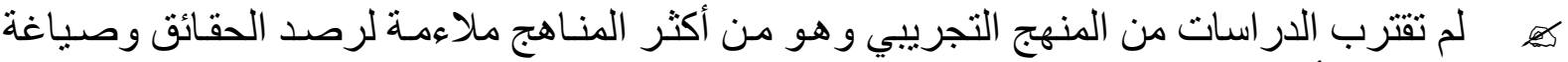

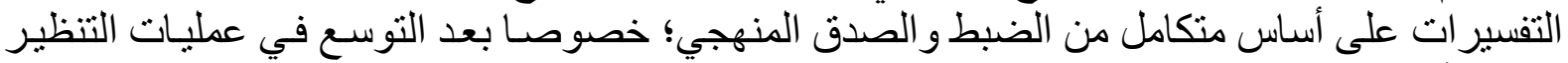

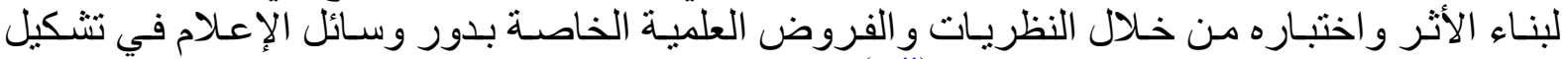

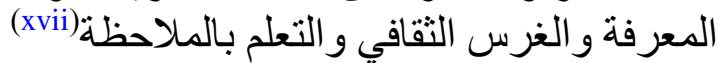

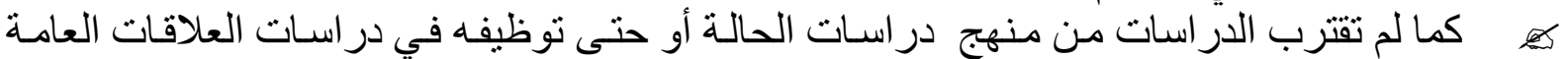

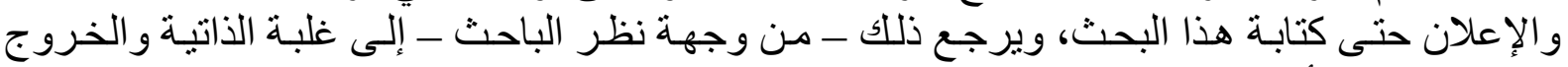

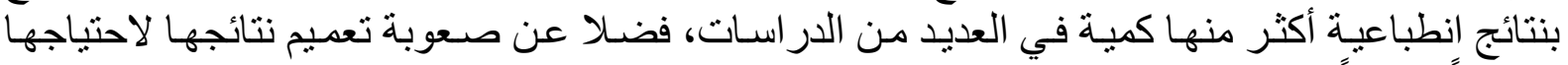

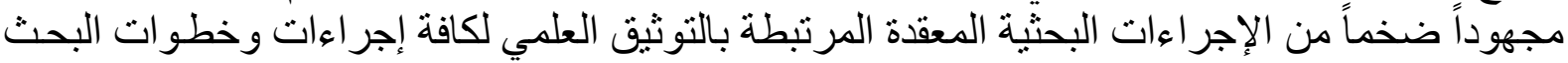

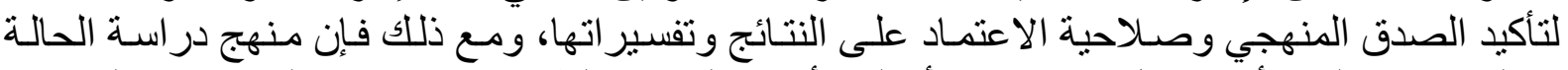
يصلح - بلا شك - أن ينكامل مع مناهج و أساليب أخرى لدر اسة الظو اهر الإعلامية التي تنسم بالتركيب و التعقيد.

كها

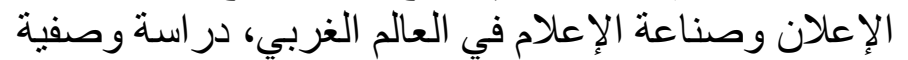

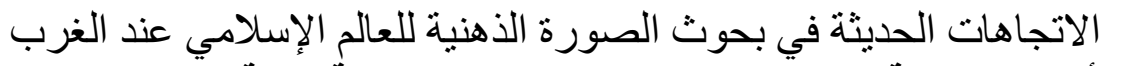

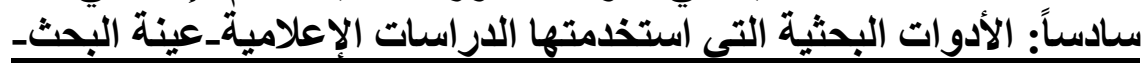

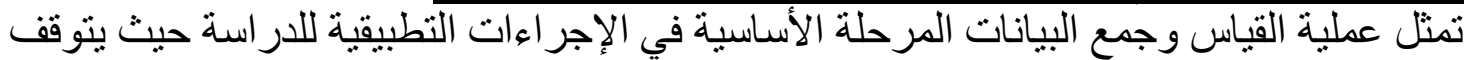

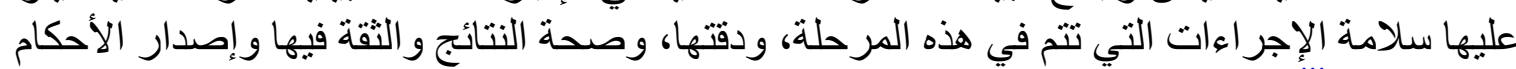

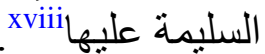

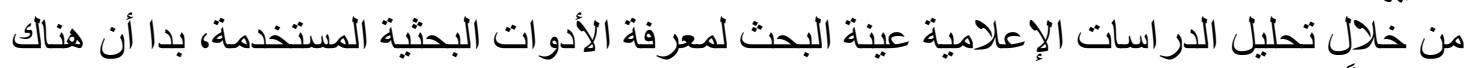

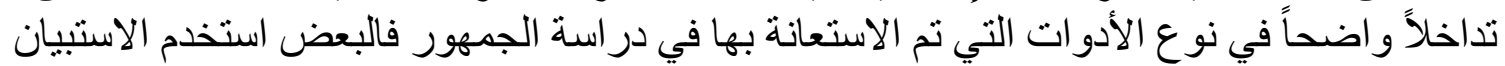

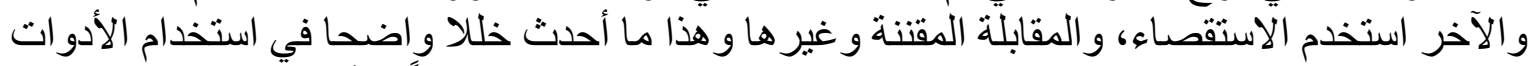

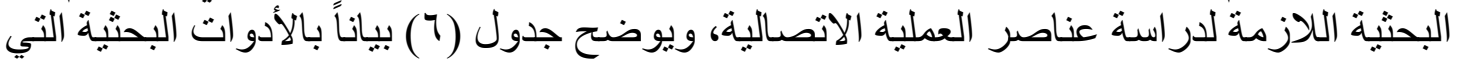

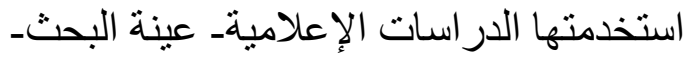




\begin{tabular}{|c|c|c|c|c|c|c|c|}
\hline \multirow[b]{2}{*}{$\%$} & \multirow[b]{2}{*}{ Total } & \multicolumn{5}{|c|}{ تصنيف البحث } & \multirow[b]{2}{*}{ أدوات البحث } \\
\hline & & خطة مسجلة & خطة مسجلة & ماجستير & دكتوراه & بحوثلة منشورة & \\
\hline ro. & iv & $\varepsilon$ & - & r & r & 9 & الاستبيان \\
\hline $1 \wedge . \wedge \%$ & 9 & r & - & 1 & - & 0 & تحليل المضمون \\
\hline $1 \leq .7 \%$ & V & - & - & 1 & - & 7 & الاستقصاء \\
\hline $1 \varepsilon .7 \%$ & v & 0 & 1 & - & - & 1 & تحليل المضمون والاستبيان \\
\hline$\varepsilon . r \%$ & r & - & - & - & - & r & لم يبين \\
\hline r.1\% & 1 & - & - & - & - & 1 & استمـارة التحليل \\
\hline$r .1 \%$ & 1 & - & - & 1 & - & - & المقابلة \\
\hline$r .1 \%$ & 1 & - & - & 1 & - & - & المقابلة المقتنة \\
\hline Y.1\% & 1 & - & - & 1 & - & - & تحليل المضمون والاستقصاء \\
\hline$r .1 \%$ & 1 & - & - & 1 & - & - & تحليل المضمون والمقابلة \\
\hline$r .1 \%$ & 1 & - & - & - & 1 & - & تحليل المضمون والتحليل \\
\hline \multirow{2}{*}{$1 \ldots \%$} & \multirow{2}{*}{$\varepsilon \wedge$} & 11 & 1 & $\wedge$ & $r$ & ro & Total \\
\hline & & r. . $৭ \%$ & r.1\% & $17.8 \%$ & $7 . r \%$ & or. $1 \%$ & $\%$ \\
\hline
\end{tabular}

من خلال تحليل قراءة بيانات الجدول (7) يتضح الآتي:

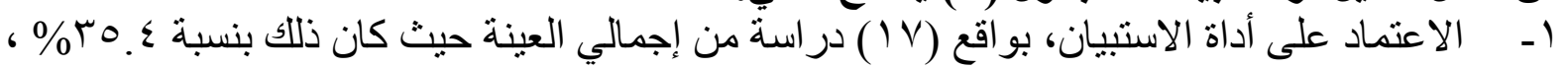
ومن بين تللك الدر اسات:

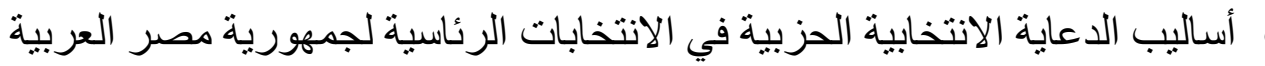

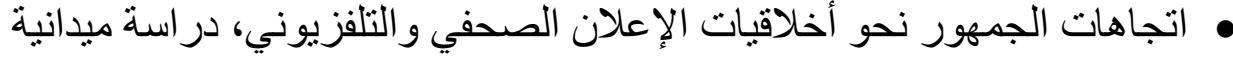

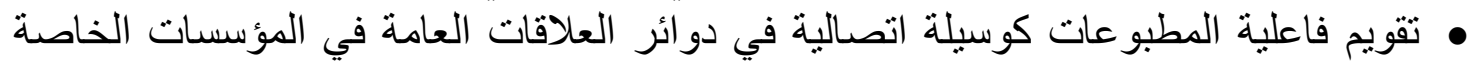
بقطاع غزة، در اسة وصفية تحليلية • تقييم طلاب أقسام العلاقات العامة للاراسات التخصصية ، و وانعكاسه على اتجاهاتهم نحو

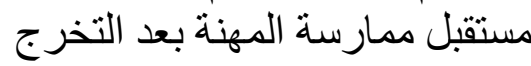

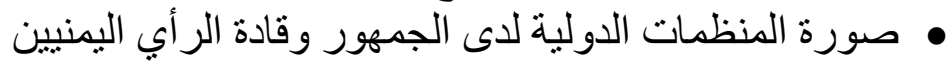

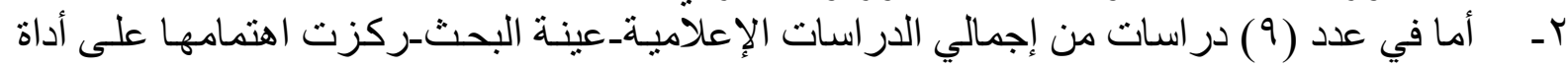

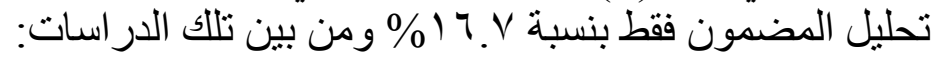

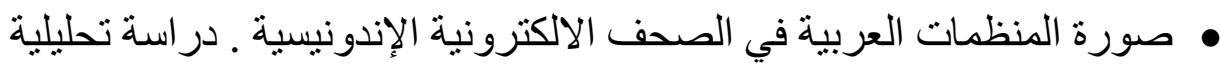

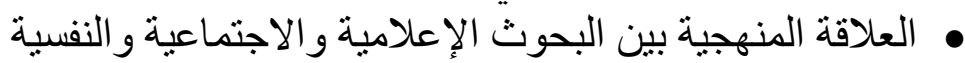
ه الإعلان التحريري في الصحافة المصرية الاعدية الاجية 


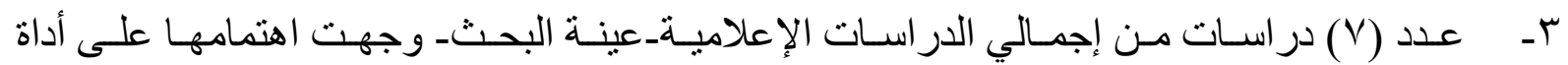

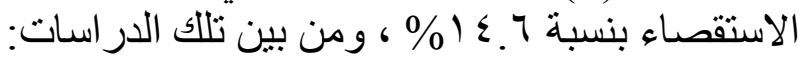

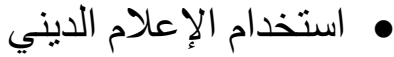

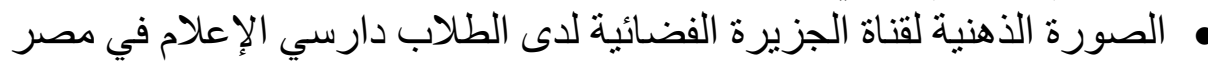

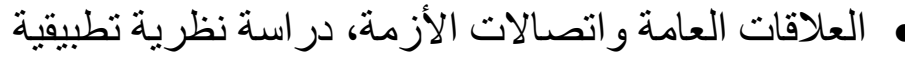
• تقييم الجمهور المصري للحملات الانتخابية لمرشحي الرئاسة المصنية درية وتغطيتها الإعلامية

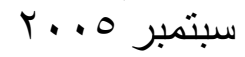
• دور الإعلانات التلفزيونية في تقديم السلوك الثرائي للثباب ، دراسة ميدانية على عينة من

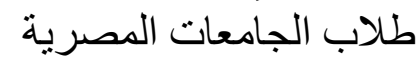

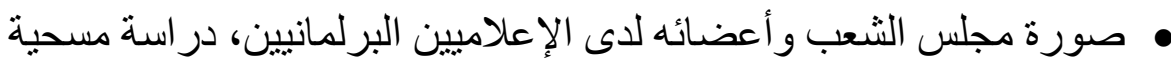

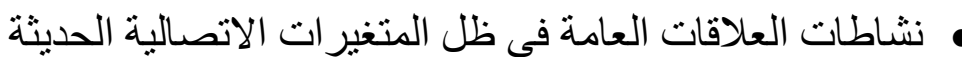

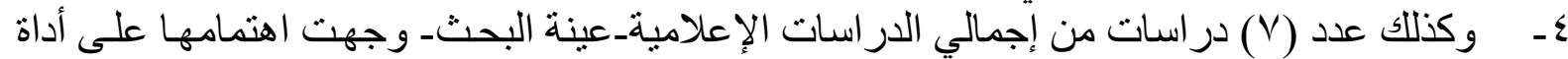

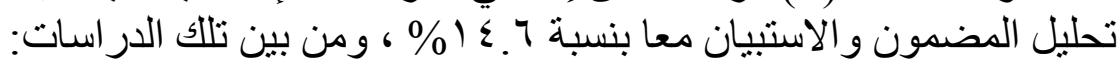

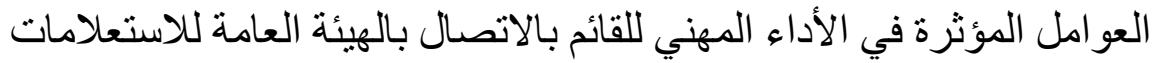

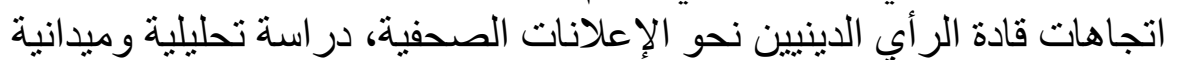

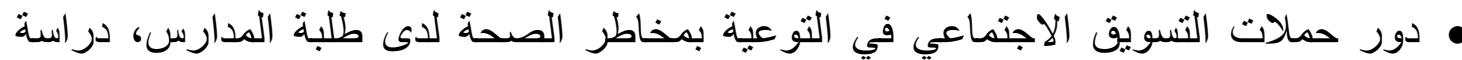
تطبيقية

• صورة القضاء في الصحف المصرية، دراسة تطبيقية

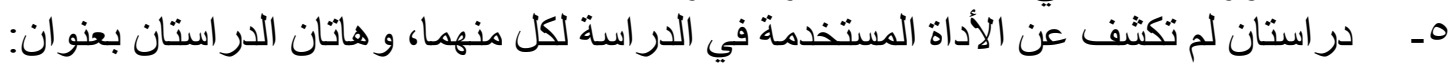

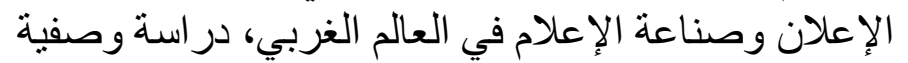

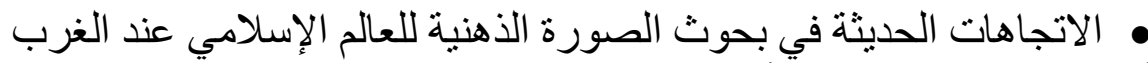

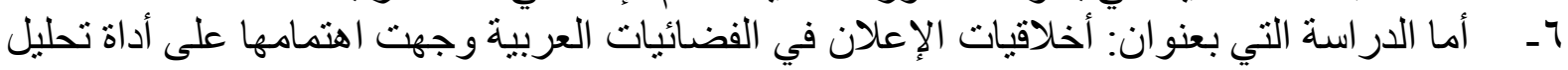

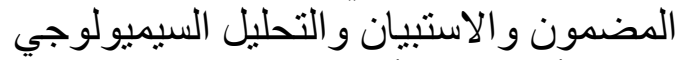

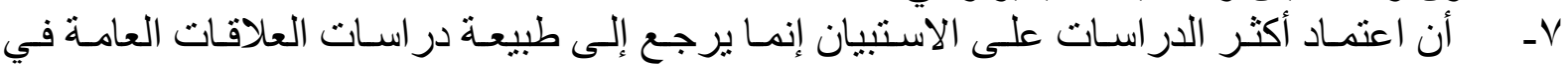

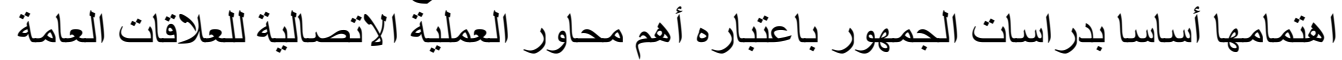

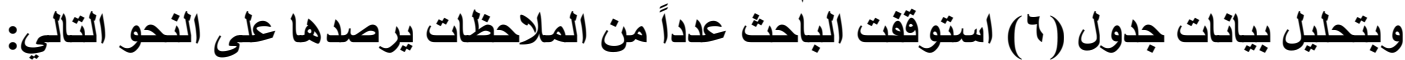

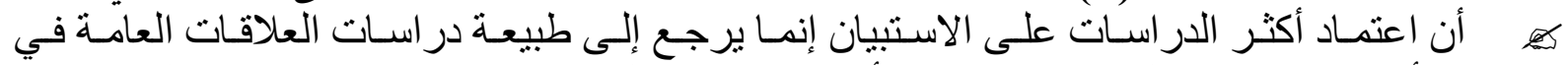

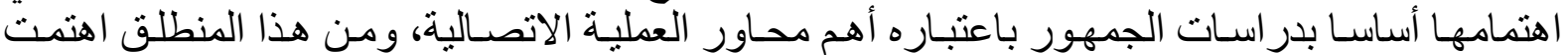

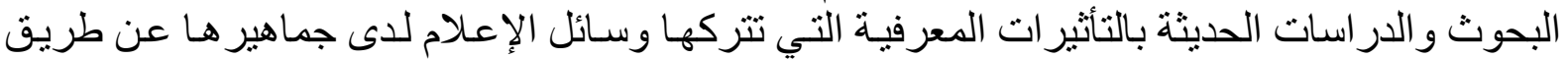

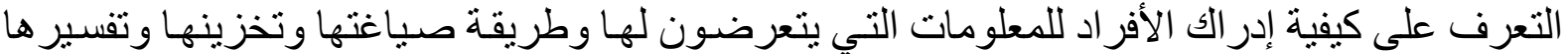

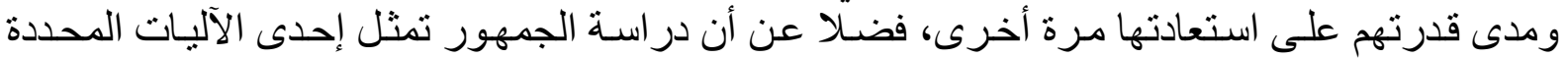

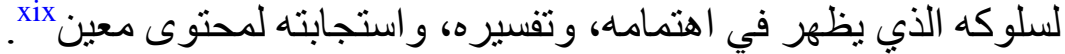

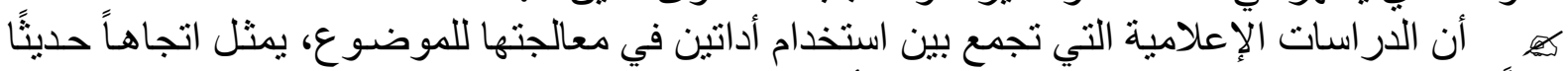

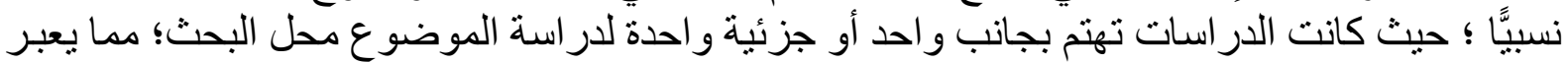

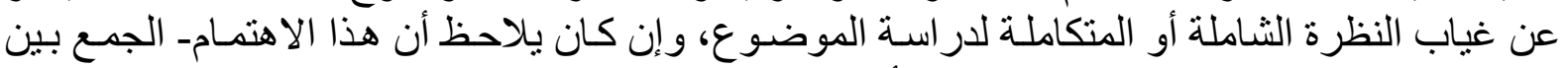
در اسة المضمون و الجمهور - قد سجل معدلا أكبر مع بداية فترة التسعينات بنسب تعادل الضعاد الضعف. 


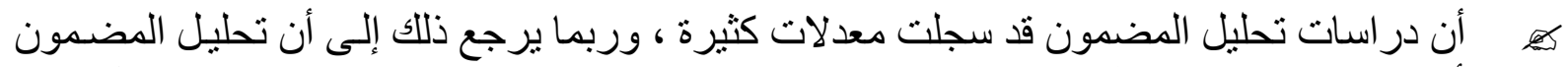

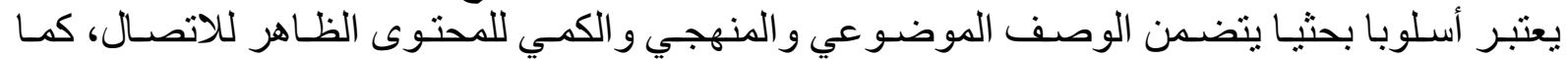

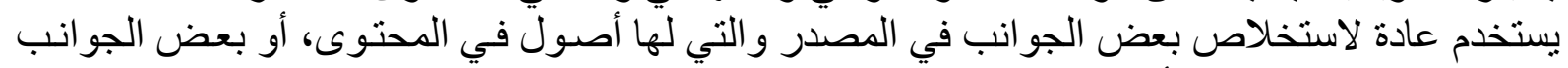

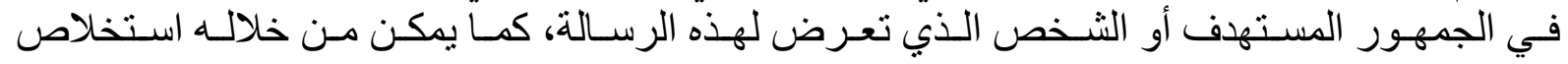

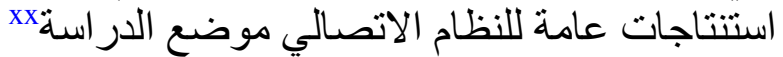

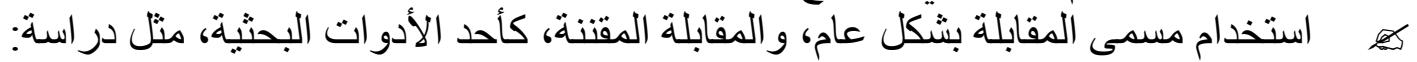

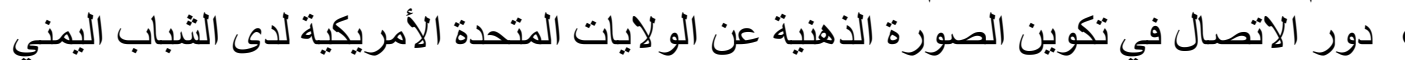

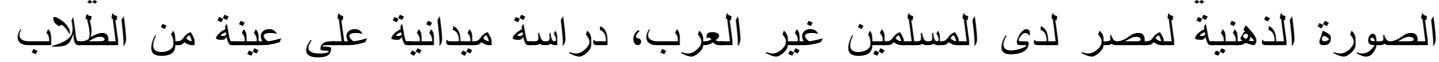

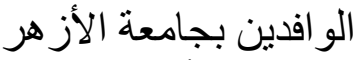

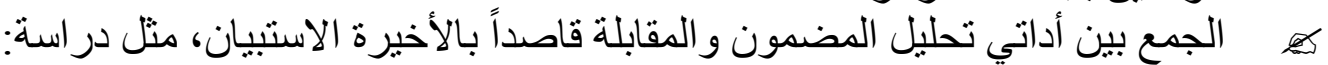

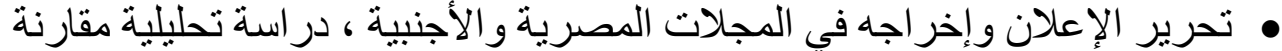

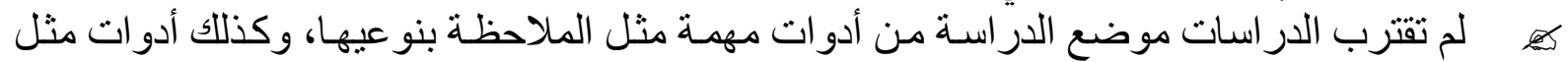
مجمو عات النقاش المركزة، و المقابلات المتعمقة.

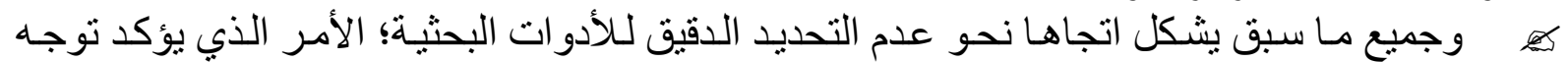

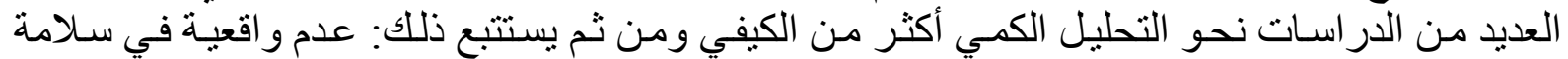

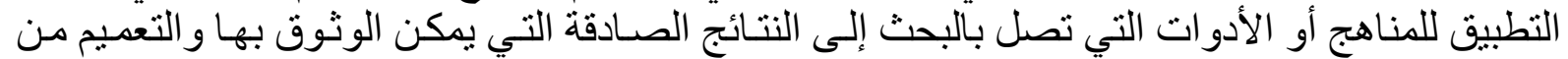

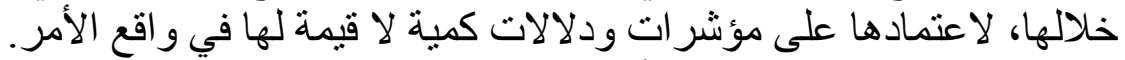

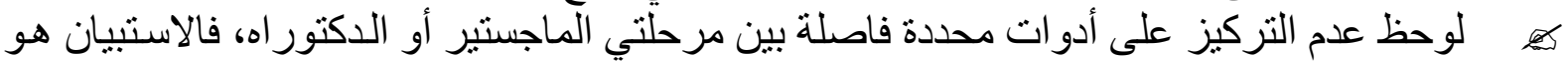

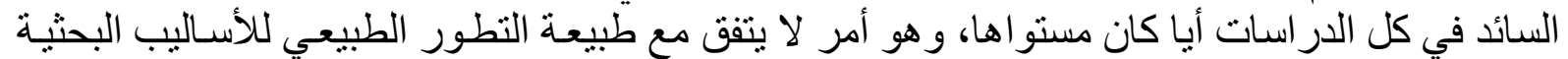

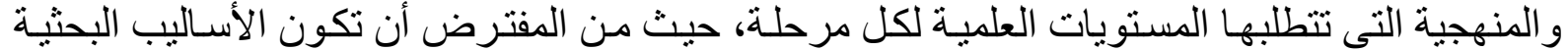

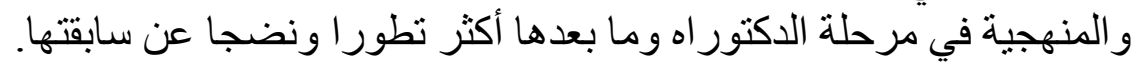

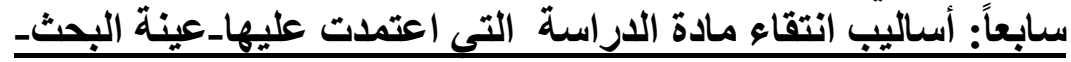

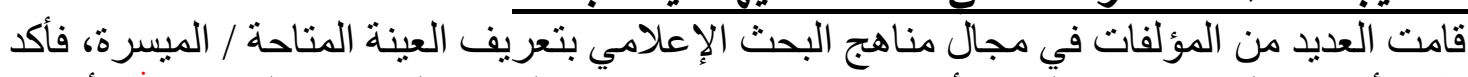

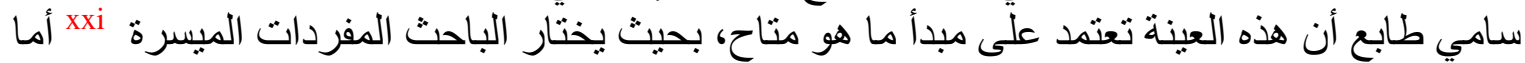

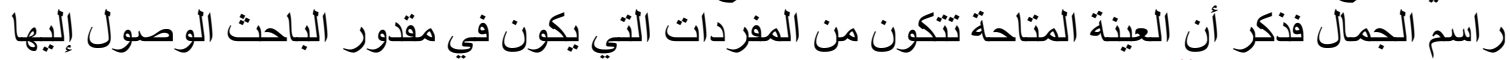

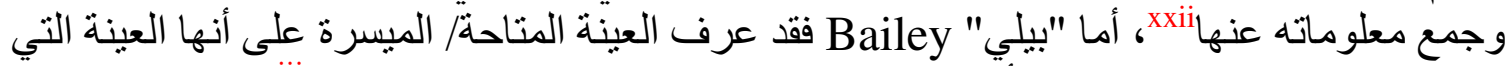

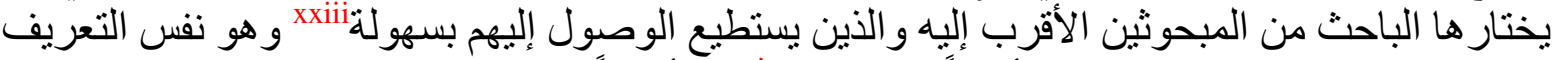

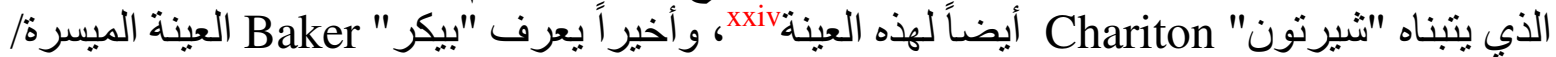

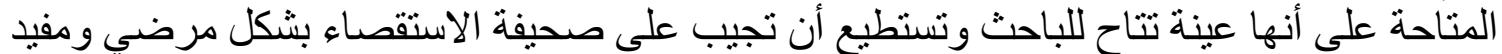

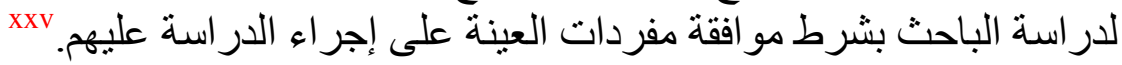


جدول (V) يبين - أساليب انتقاع مادة الدراسة التي اعتمدت عليها-عينة البحث

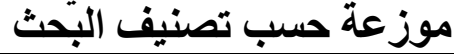

\begin{tabular}{|c|c|c|c|c|c|c|c|}
\hline \multirow[b]{2}{*}{$\%$} & \multirow[b]{2}{*}{ Total } & \multicolumn{5}{|c|}{ تصنيف البحث } & \multirow[b]{2}{*}{ عينة البحث } \\
\hline & & لمسجلة & |لاكتّزة & ماجستير رسائل & دكتوراه & منشوبلة بملثة & \\
\hline rV. $1 \%$ & $T r$ & $\overline{0}$ & $T$ & $T$ & $T$ & 0 & عينة عمدية \\
\hline $17.8 \%$ & $\Lambda$ & $r$ & - & 1 & - & 0 & عينة عشوائية \\
\hline $17 . \vee \%$ & $\Lambda$ & $r$ & - & $T$ & - & 0 & حصر شامل \\
\hline $1 \leqslant .7 \%$ & $v$ & - & - & 1 & - & 7 & لم يبين \\
\hline $7 . r \%$ & $r$ & - & - & r & - & 1 & عينة عشئة طائية / \\
\hline $7.5 \%$ & $r$ & $T$ & - & - & - & $\bar{r}$ & عينة طبقية \\
\hline$\varepsilon . Y \%$ & $Y$ & - & - & 1 & 1 & - & العينة متعددة المراحل \\
\hline$r .1 \%$ & 1 & - & - & - & 1 & - & عينة عمدية / للجمهورينة \\
\hline$r .1 \%$ & 1 & 1 & - & - & - & - & عينة عشوائية / عينة المدية \\
\hline Y. $1 \%$ & 1 & - & - & - & - & $T$ & عينة حصصية \\
\hline$r .1 \%$ & 1 & - & - & 1 & - & - & وعينة احتمالية / عثمية \\
\hline \multirow{2}{*}{$1 \ldots \%$} & \multirow{2}{*}{$\leq \wedge$} & 11 & $T$ & $\Lambda$ & $r$ & ro & Total \\
\hline & & $r$ r.q\% & Y. $1 \%$ & $17.8 \%$ & $7 . r \%$ & or. $1 \%$ & $\%$ \\
\hline
\end{tabular}

عند استقرائنا لبيانات جدول (V)، و الذي يوضح نوع العينات التي استخدمتها الدراسات الإعلامية_عينة

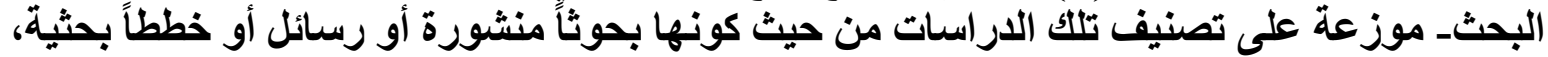

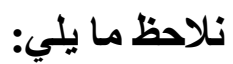

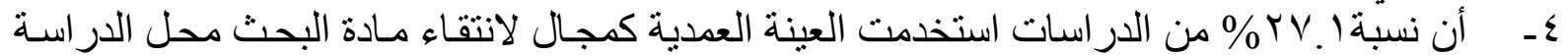

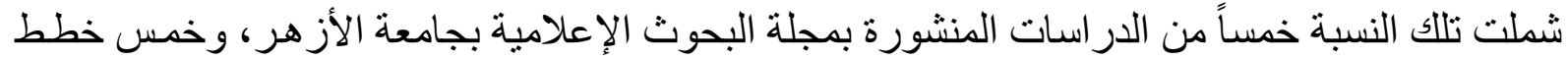

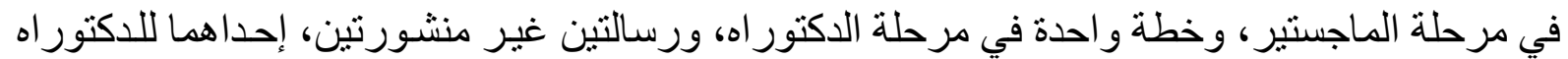

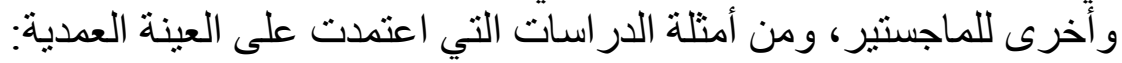

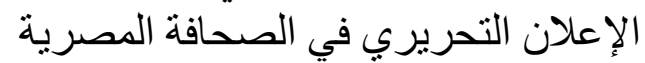

الاتجاهات الإعلانية في المحطات الفضائية العربية الإنية

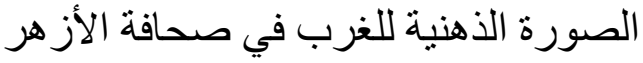
العو امل المؤثرة في تحريز العنوان الإعلاني 


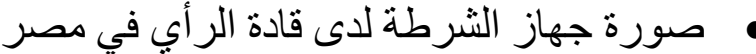

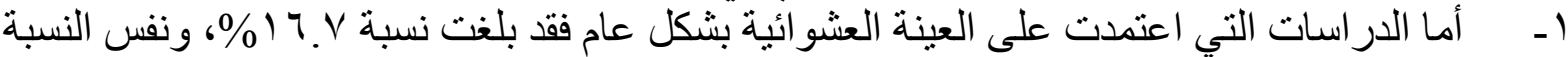

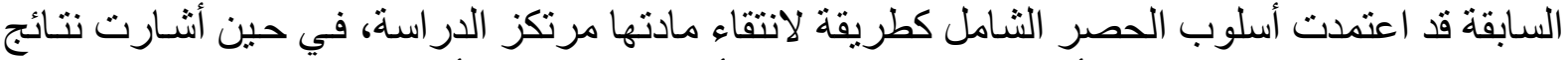

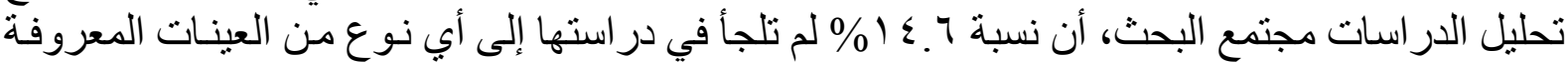

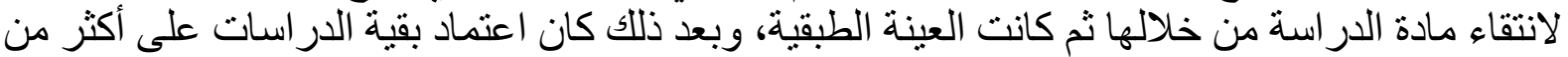

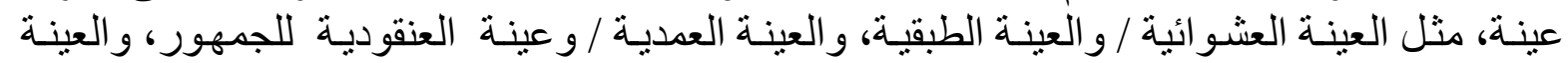

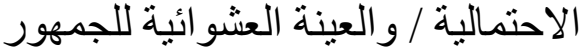

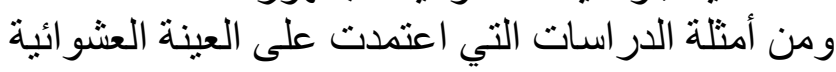

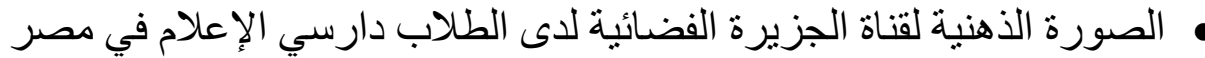

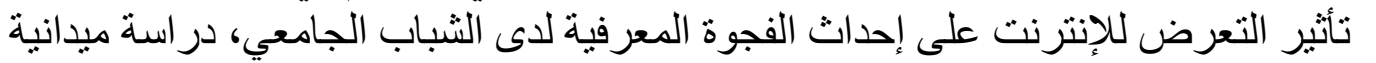

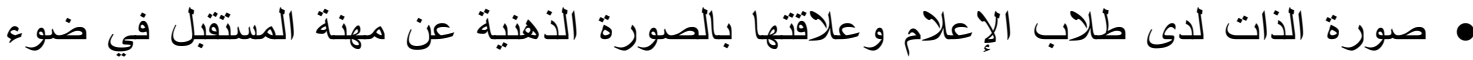

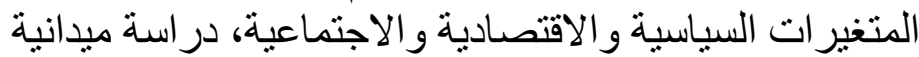

ومن أمتلة الدراسات التي اعتمدت على أسلوب الحصر الثنامل كطريقة لانتقاء مادتها

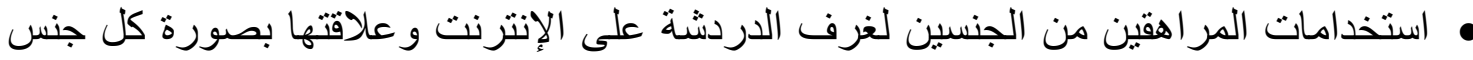

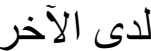

• العلاقة المنهجية بين البحوث الإعلامية والاجتماعية والنفسية • تقويم فاعلية المطبوعات كوسيلة اتصالية في دوائر العلاقات العامة الفية في المؤسسات الخاصة بقطاع غزة، در اسة وصفية تحليلية ه تقييم طلاب أقسام العلاقات العامة للاراسات التخصصية ، و وانعكاسه على اتجاهاتهم نحو

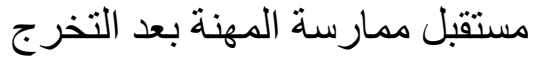
• • صورة مجلس الثعب و أعضائه لدى الإعلاميين البرلمانيين، در اسة مسحية ومما سبق يمكن استنتاج ما يلي:

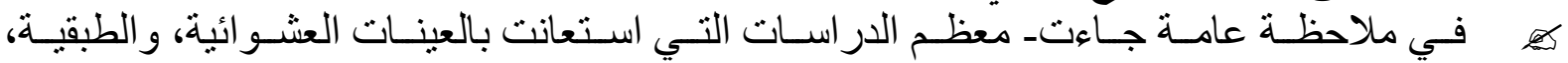

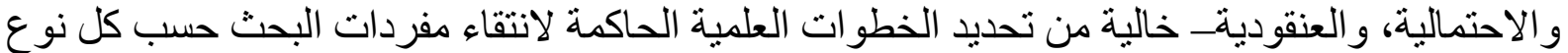

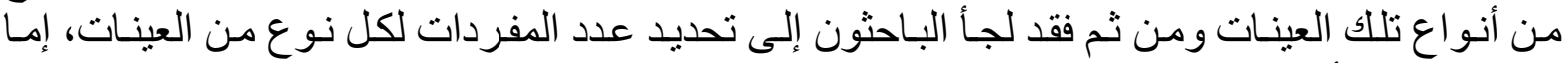

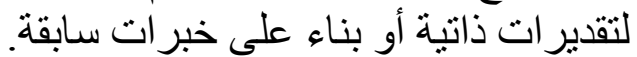

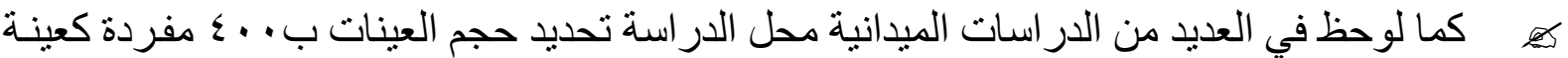

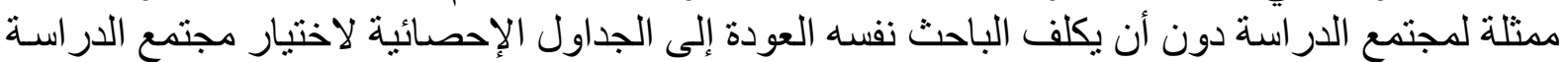

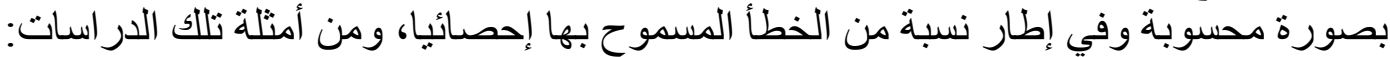

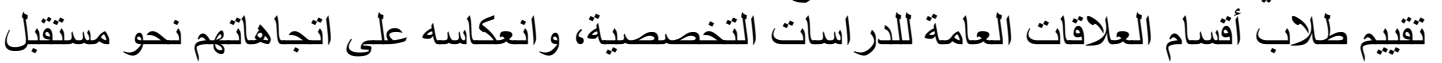

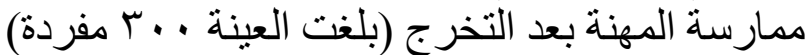
• استخدامات المر اهقين من الجنسين لغرف العينة الدردشة على العنى الإنترنت و علاقتها بصورة كل جنس

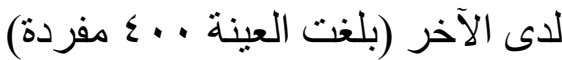

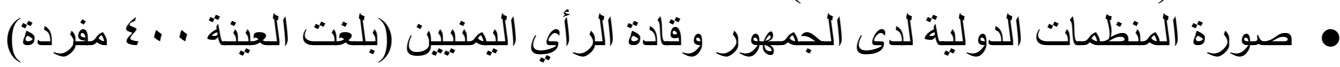

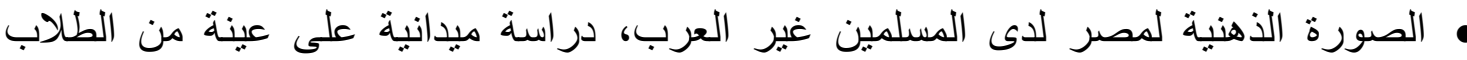


ثامناً: تصنيف الار اسات الإعلامية ـ عينة البحثـ من حيث صياغة الفروض أو طرح التساؤلات

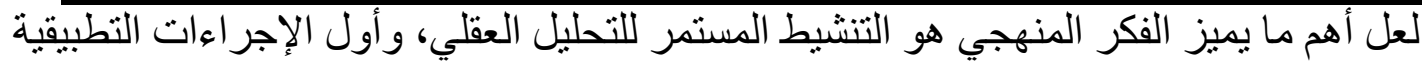

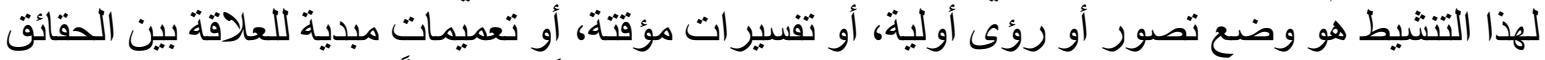

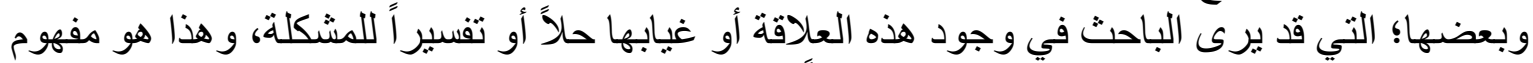

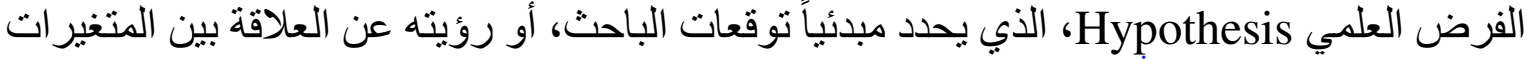

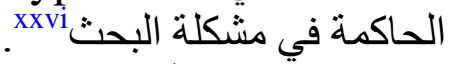

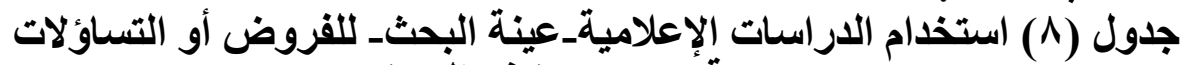
موزعة حسب تصنيف الإعلة البحثة

\begin{tabular}{|c|c|c|c|c|c|c|c|}
\hline \multirow[b]{2}{*}{$\%$} & \multirow[b]{2}{*}{ Total } & \multicolumn{5}{|c|}{ تصنيف البحث } & \multirow[b]{2}{*}{ فروض وتساؤلات } \\
\hline & & لالمسجة & لالدرجة الدجة & ماجستير & دكتوراه & بمجنوية بملثة & \\
\hline$\Delta \wedge . \mu \%$ & rA & 11 & 1 & $\varepsilon$ & $\overline{1}$ & 11 & تساؤلات فقةط \\
\hline$r$ r. $9 \%$ & 11 & - & - & $\varepsilon$ & 1 & 7 & تروضاؤلات و \\
\hline $1 \cdot . \leqslant \%$ & 0 & - & - & - & $T$ & $\varepsilon$ & فروض فقط \\
\hline$r .1 \%$ & 1 & - & - & - & - & 1 & فروضؤال و \\
\hline$r .1 \%$ & 1 & - & - & - & - & 1 & تروض تشاؤلات واحد \\
\hline$Y .1 \%$ & $T$ & - & - & - & - & $T$ & تساؤل واحد \\
\hline$r .1 \%$ & $T$ & - & - & - & - & $T$ & لا يوجد \\
\hline \multirow{2}{*}{$1 . . \%$} & \multirow{2}{*}{$\varepsilon \wedge$} & 11 & 1 & $\Lambda$ & $r$ & ro & Total \\
\hline & & YY.Q\% & Y. $1 \%$ & $17.8 \%$ & $7 . r \%$ & or. $1 \%$ & $\%$ \\
\hline
\end{tabular}

يكثف التحليل الإحصائي للجدول رقم (^) بيانا باستخدام الاراسات الإعلامية_عينة البحثـ للقروض أو الت

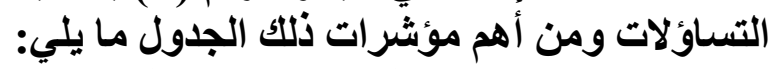

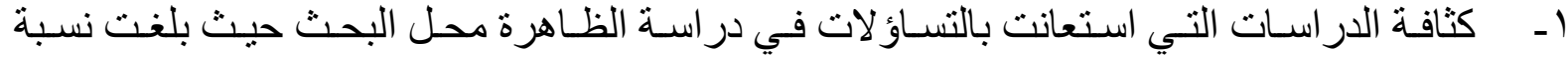

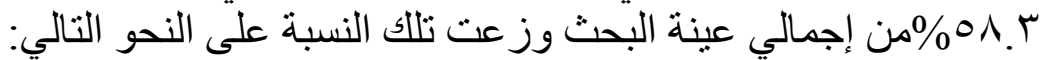

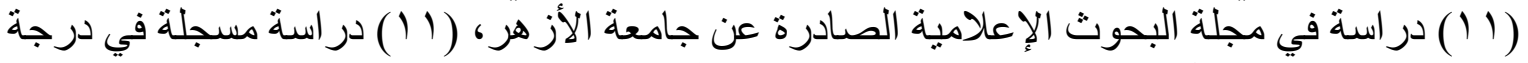

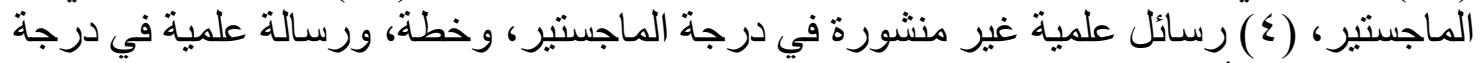
الدكتور اه؛ ومن أمثلة تلك الدار اسات:

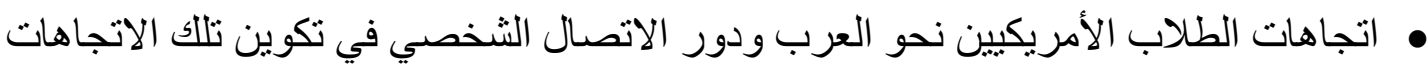

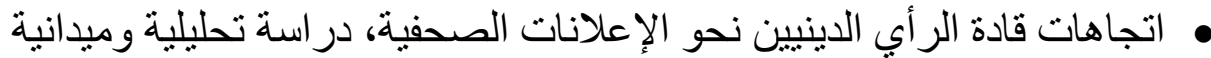

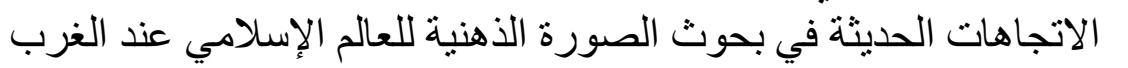
• اتجاهات الطلاب الأمريكيين نحو العرب ودور الاتصال الثخصي في تكوين تلك الاتجاهات 
• اتجاهات قادة الر أي الدينيين نحو الإعلانات الصحفية، در اسة تحليلية وميدانية

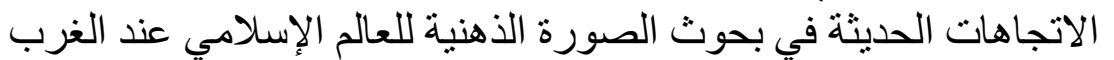

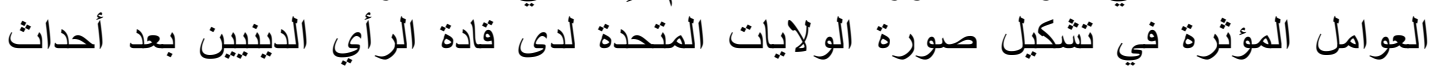

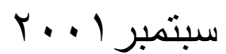

تأثثر الفضائيات الموجهة بالعربية في تشكيل الصورة الذهنية عن الدول الأوروبية لدى

المصريين، در اسة تطبيقية

• صورة الإسلام و المسلمين في مجلتي النيوز ويك وفورن بونة بولسي الصادرتين بالعربية في المدة

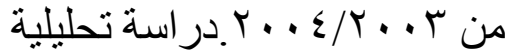

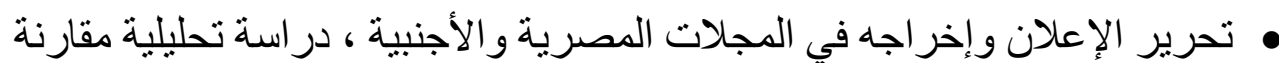

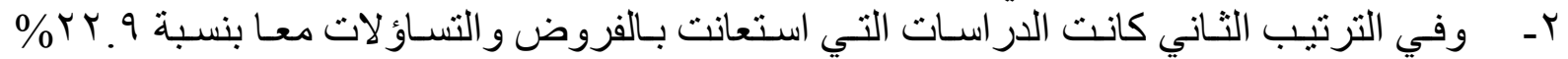

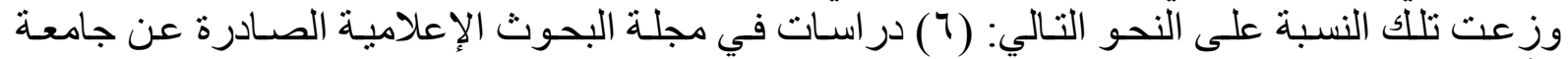
الأز هر، (ع ) رسائل علمية غير منشورة في درجة الماجستير، ورسالة علمية في درجة الدكتور اه، ومن أمثلة تللك الدز (عاست:

• احتياجات التدريب وتقييمه لدى العاملين في العلاقات العامة، دراسة على شركات مصرية

وخليجية

• دور الإعلانات التلفزيونية في تقديم السلوك الثرائي للشباب ، دراسة ميدانية على عينة من

طلاب الجامعات المصرية

•

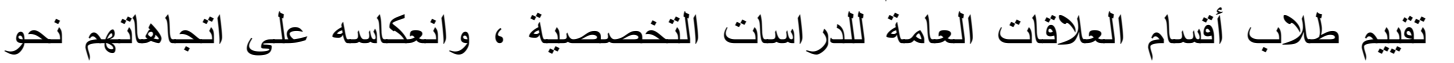

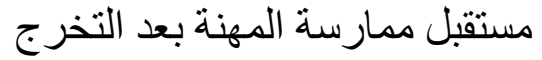

هور الاتصال في تكوين الصورة الذهنية عن الولايات المتحدة الأمريكية لإى الثباب اليمني

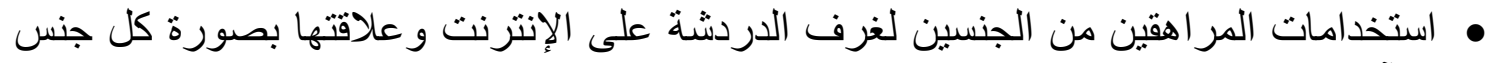
لآى الآخر

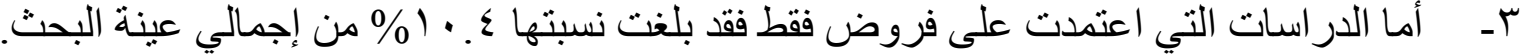

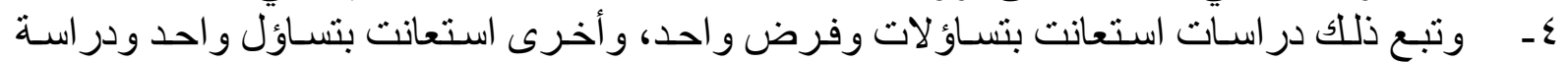

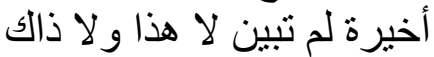

\section{ومما سبق يمكن للباحث استنتاج ما لايلي:}

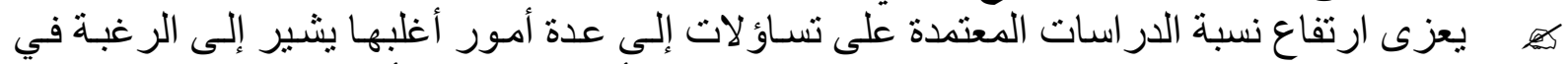

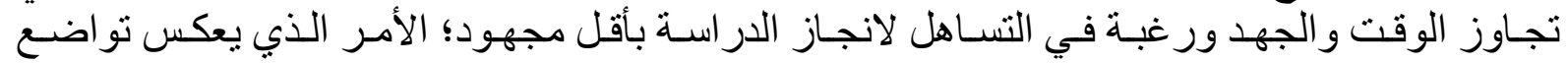
إمكانيات بعض الباحثين نحو الملاحظة العلمية للظاهرة وحركة المتغير ات من حولها والتي تستدعي بناء

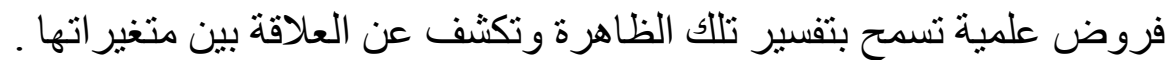

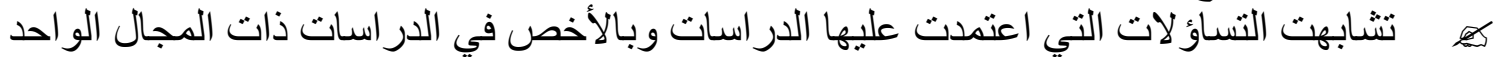

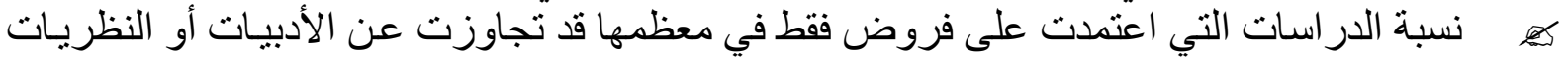

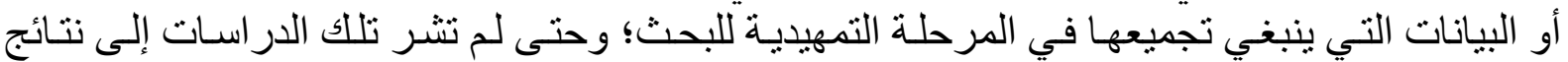

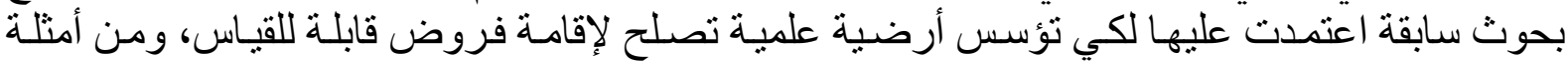

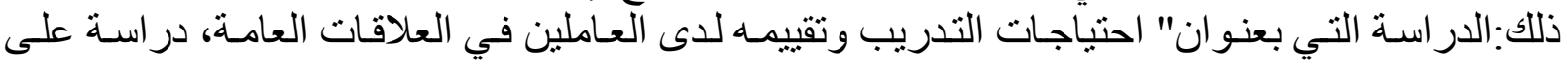


شـركات مصـرية وخليجيـة" وفيهـا الفرض القائلـ:" بأنـه توجد فروق ذات دلالـة إحصـائية بين كل مـن

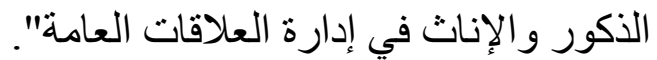

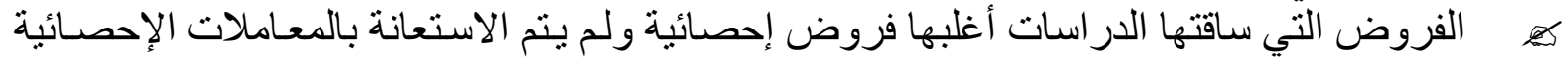

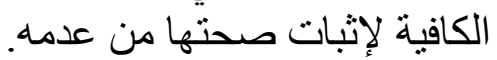

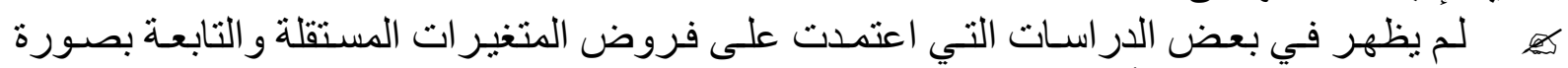

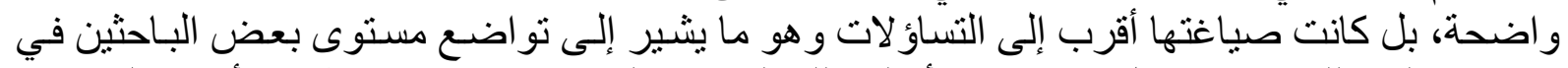

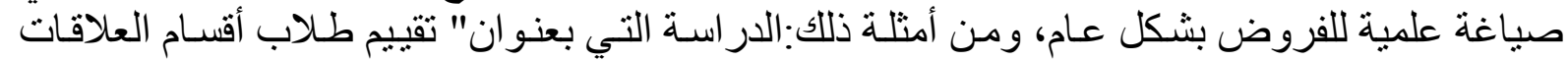

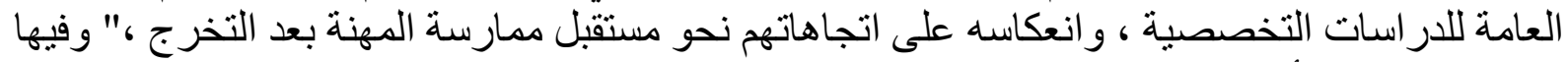

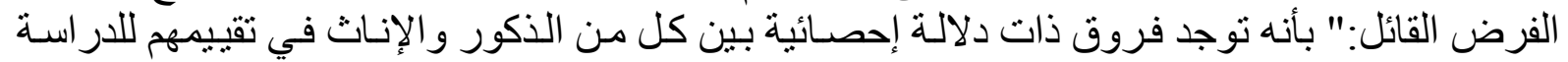

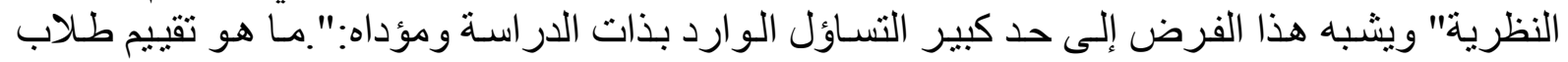

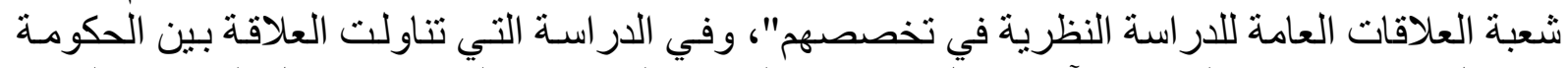

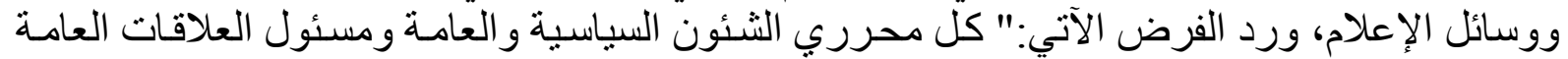

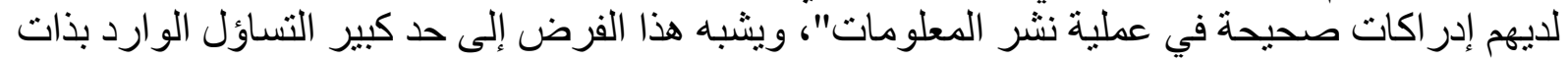

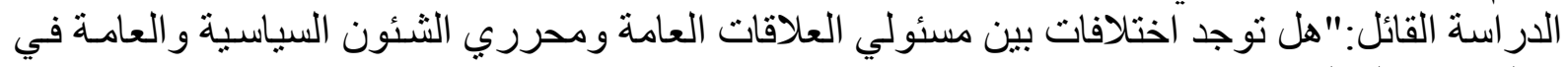
عملية نشر المعلومات؟ب".

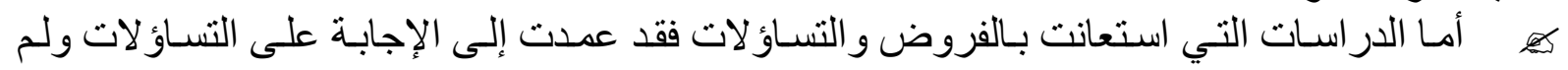

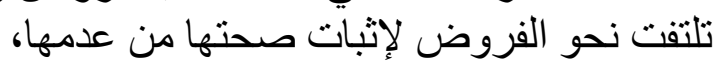

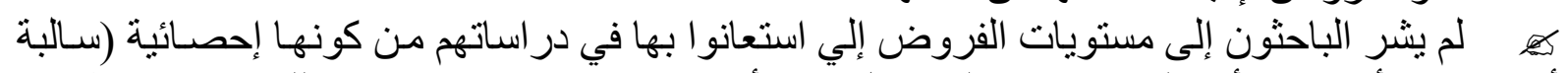

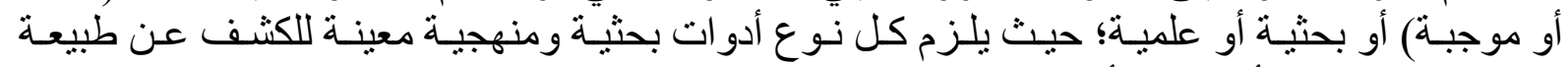

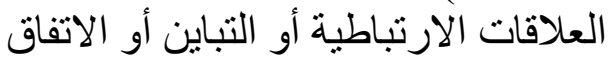

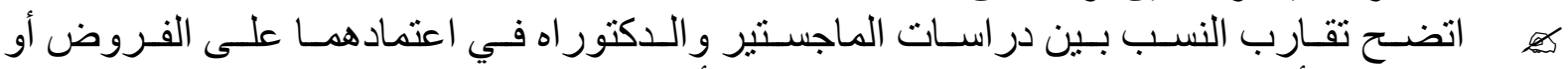

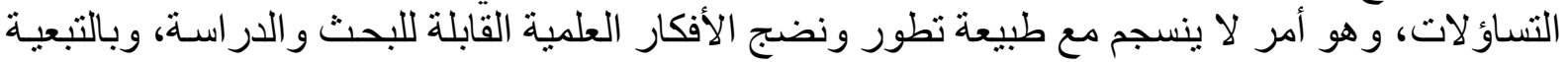

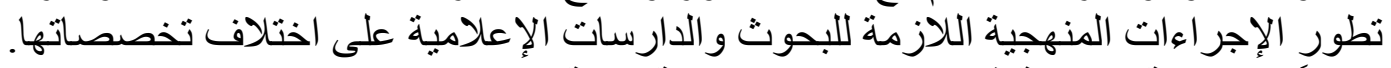

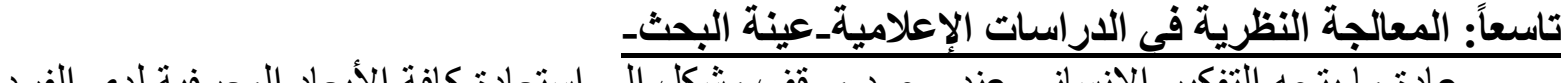

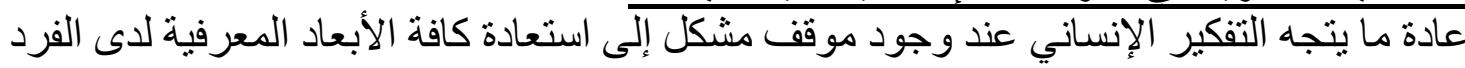

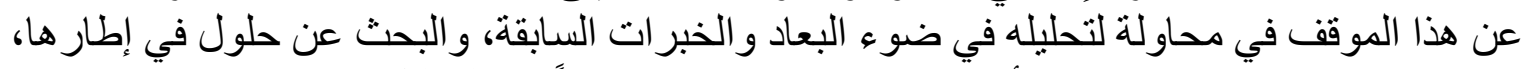

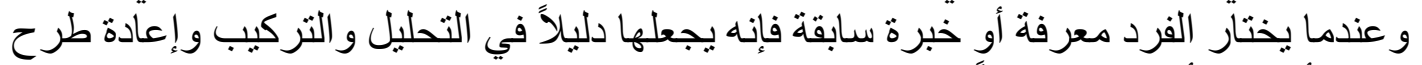

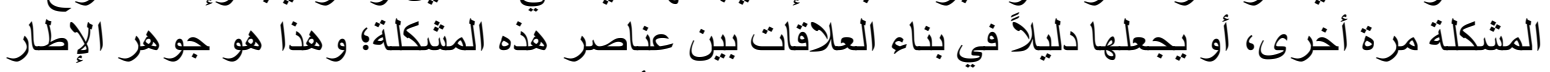

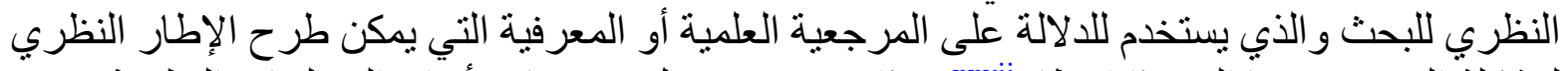

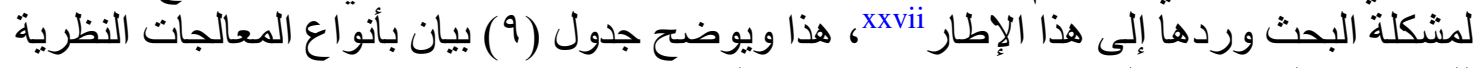

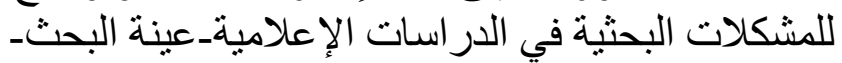


جدول (9) المعالجات النظرية المستخدمة في الدراسات الإعلامية_عينة البحثـ-

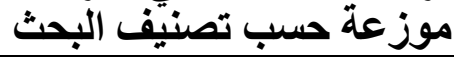

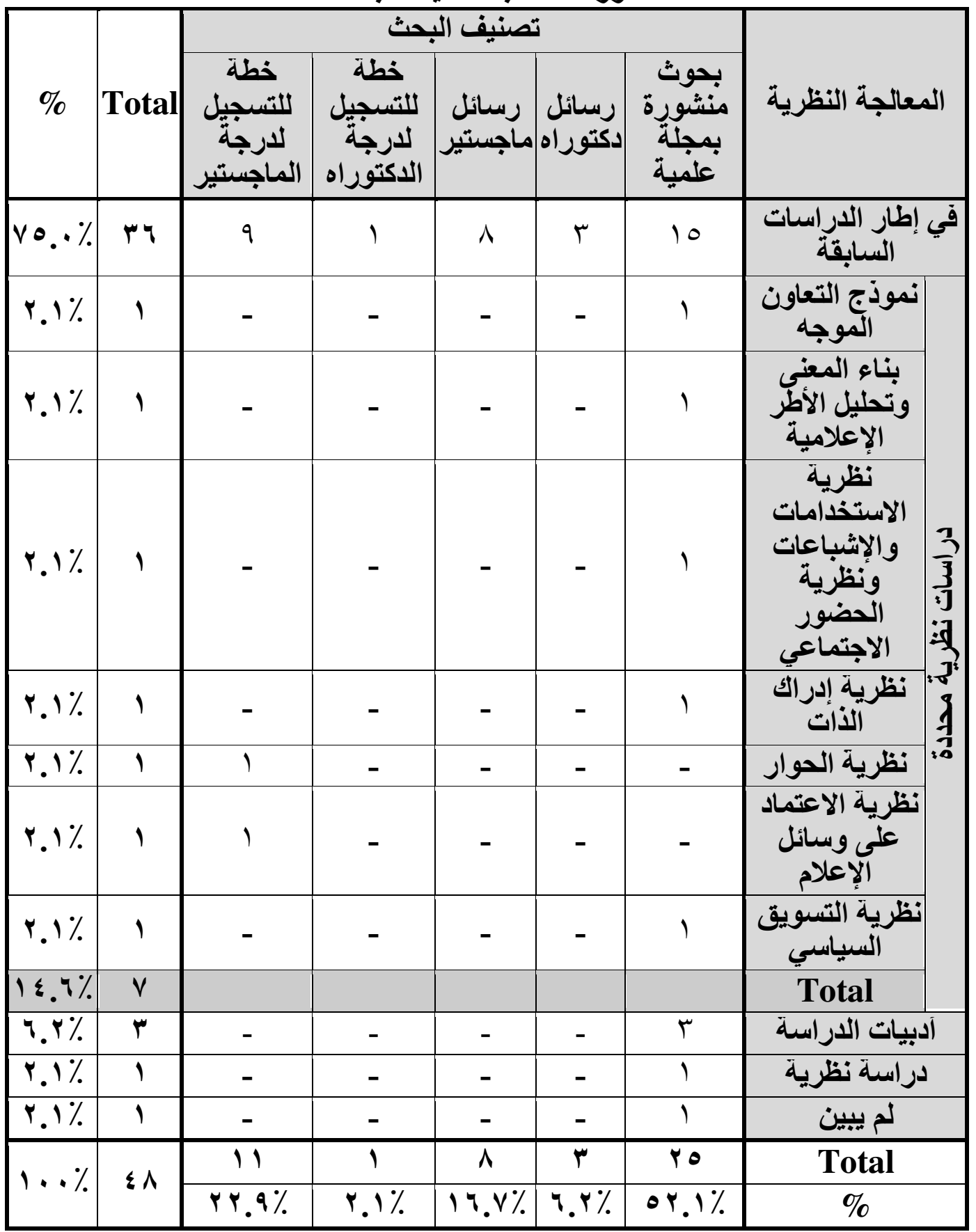

من خلال استعر اضنا للجدول السابق نلاحظ ما يلي:

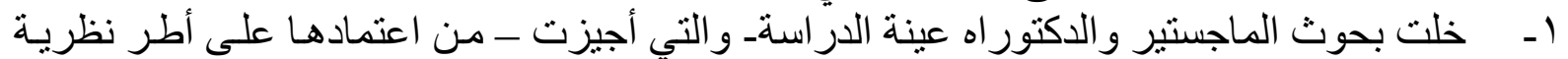

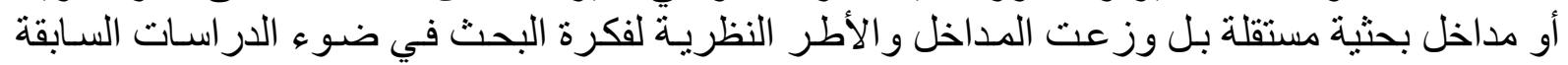
قريبة الصلة بموضوع البحث ويكتفي البحاحثون في هذا السياق بحشد وتجميع كل المعلومـات أو أغلبها 
التي عالجت فكرته بصورة مباشرة أو غير مباشرة؛ لكي بساعده ذلك على صياغة مشكلة الدراسـة التي

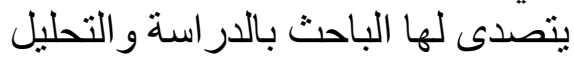

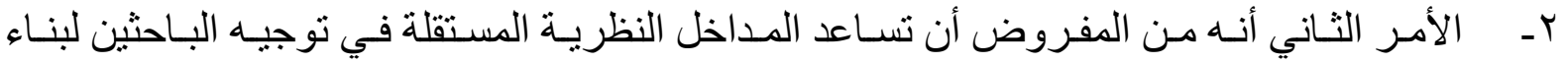

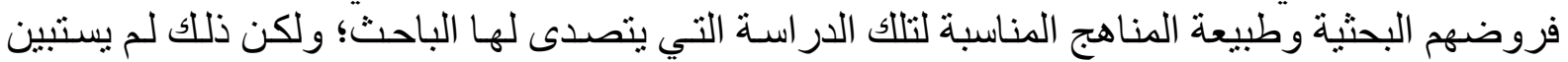
أثناء تحليلنا للار اسات التي اعتمدت على أطر نظرية مستقلة.

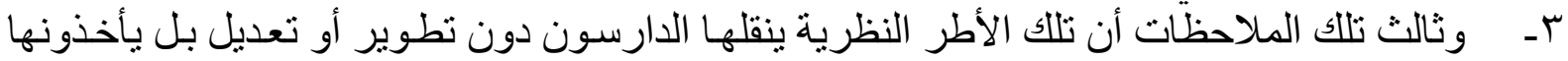

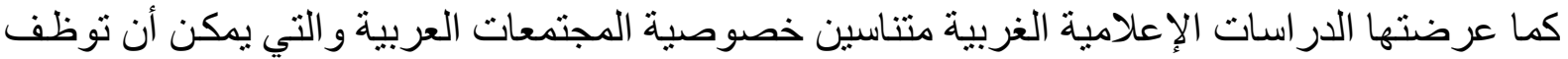

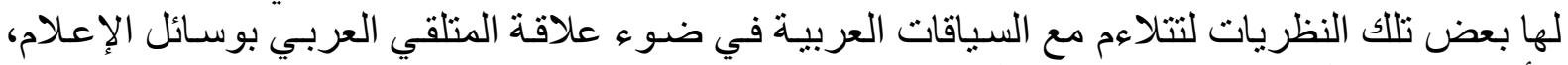

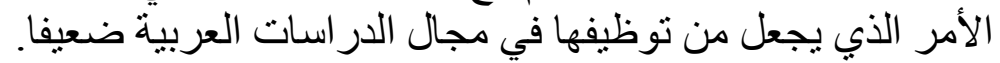

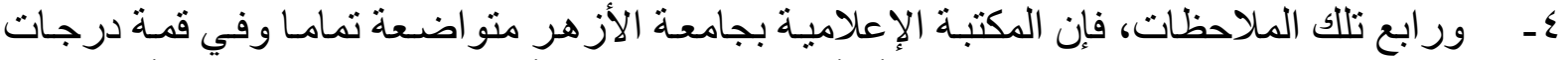

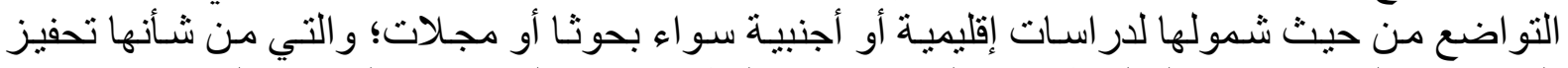

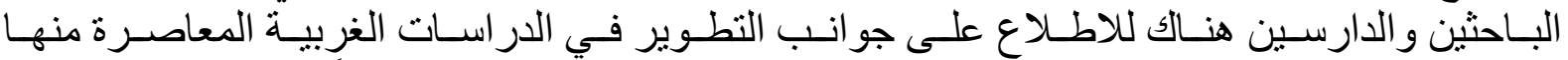

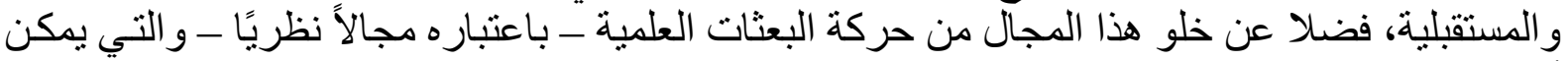

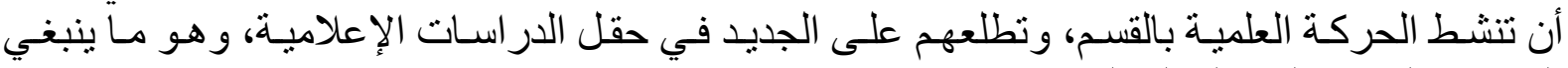
التركيز عليه في المرحلة المقبلة.

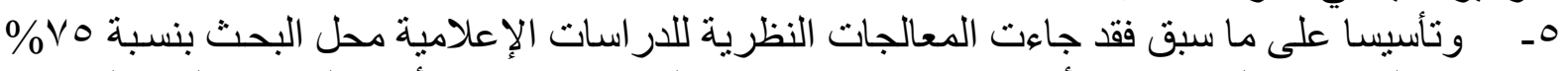

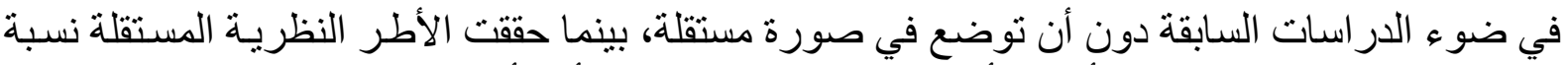

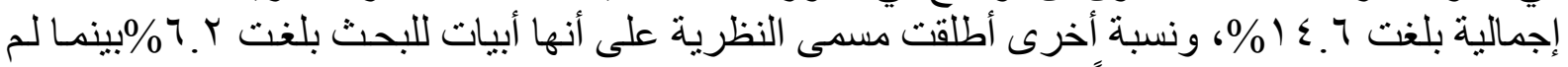

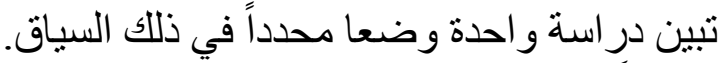

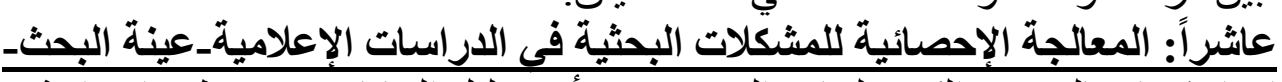

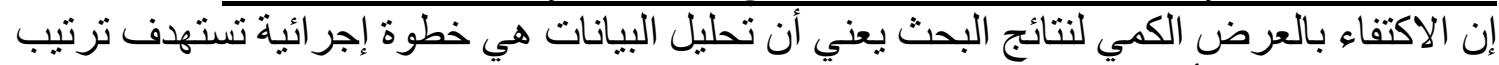

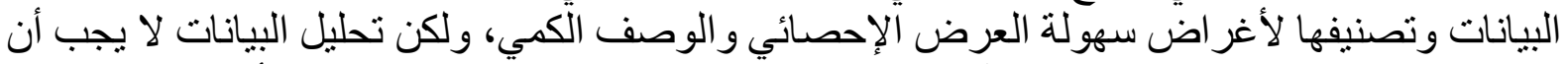

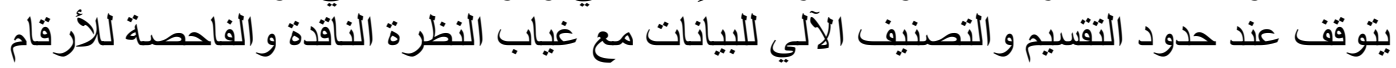

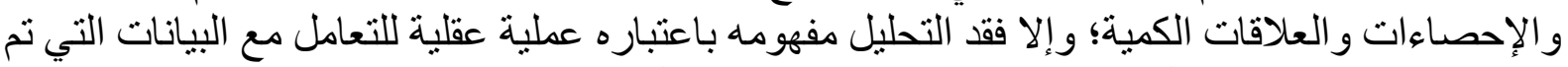

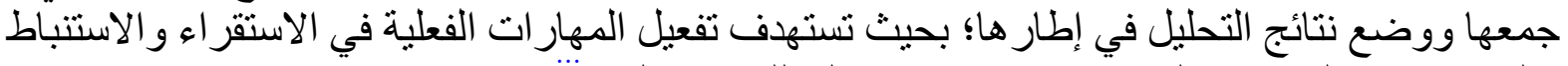

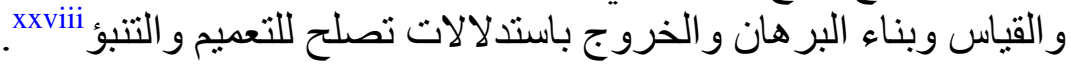


جدول (• 1 ) المعالجات الإحصائية المستخدمة في الدراسات الإعلامية_عينة البحثـموزعة حسب تصنيف البحث البث

\begin{tabular}{|c|c|c|c|c|c|c|c|}
\hline \multirow{3}{*}{$\%$} & \multirow{3}{*}{ Total } & \multicolumn{5}{|c|}{ تصنيف البحث } & \multirow{3}{*}{ المعالجات الإحصائية } \\
\hline & & مطجلة & مسجلة & رسائل | رسات & |رسائل & منشورث & \\
\hline & & الماجستير & الاكتّوزراه & & & غلمية & \\
\hline ro.. $\%$ & Ir & 11 & 1 & - & - & - & توثيُّ بالاستخدام \\
\hline ro.. & ir & - & - & - & - & Ir & تكرارات ونسبة \\
\hline $17 . \vee \%$ & $\wedge$ & - & - & $\varepsilon$ & r & 1 & 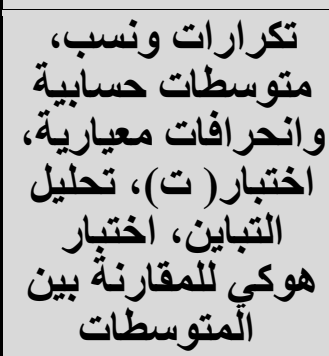 \\
\hline $1 r .0 \%$ & 7 & - & - & 1 & - & 0 & كاY ، معامل الارتباط، \\
\hline$\Lambda . r \%$ & $\varepsilon$ & - & - & - & - & $\varepsilon$ & لم يستخلم \\
\hline$\varepsilon . \uparrow \%$ & r & - & - & - & - & r & جداول بسيطة، Test \\
\hline$\varepsilon . ५ \%$ & r & - & - & r & - & - & جذاول بسيطة \\
\hline$\varepsilon . \uparrow \%$ & r & - & - & 1 & - & 1 & 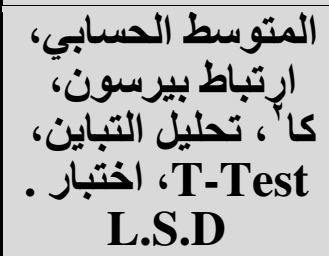 \\
\hline \multirow{2}{*}{$1 \ldots \%$} & \multirow{2}{*}{$\varepsilon \wedge$} & 11 & 1 & $\Lambda$ & $r$ & ro & Total \\
\hline & & r...\% & r. $1 \%$ & $17.8 \%$ & $7 . Y \%$ & or. $1 \%$ & $\%$ \\
\hline
\end{tabular}

ومن واقع بيانات جدول (· • ()، والذي يوضح نوع المعالجات الإحصائية التي اعتمدت عليها الدراسات

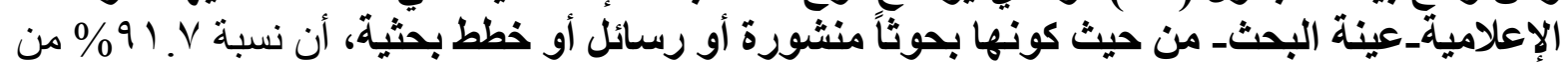

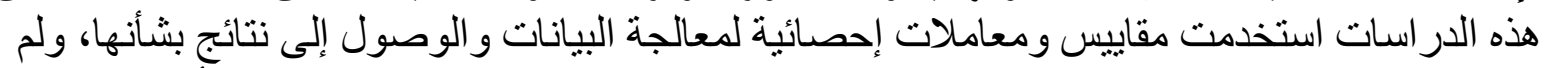

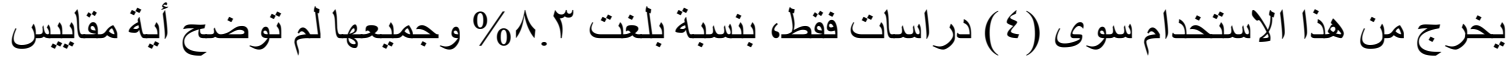
إحصائية تمت الاستعانة بها لتفسير نتائج تلأك الدر اسات ويمكن للباحث تحديد تللك المقاييس كما يبينها الجدول رقم (• • (1) على النحو التالي: 


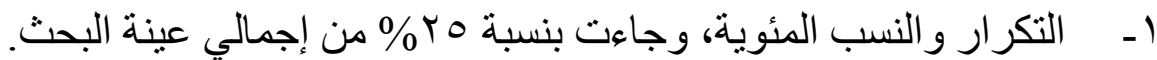

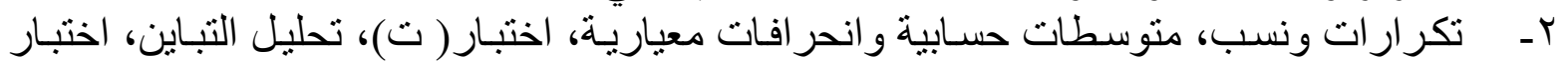

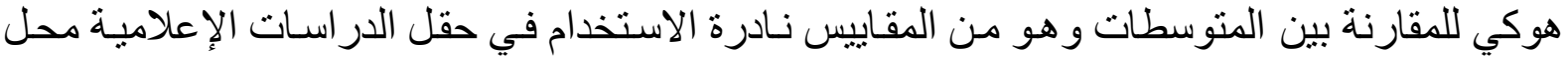

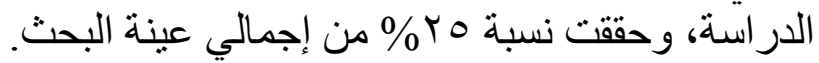

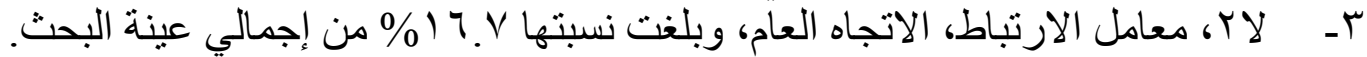

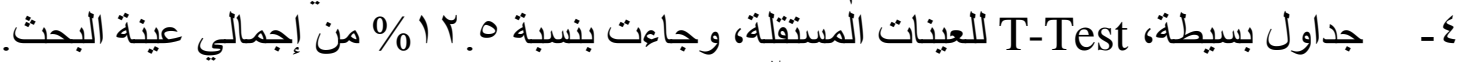

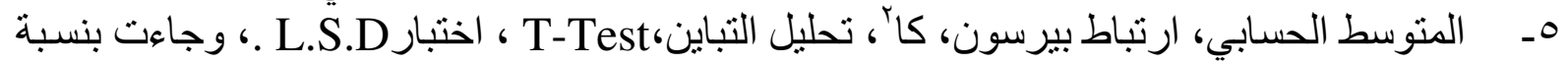

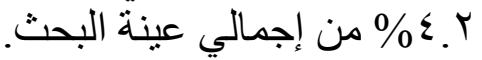

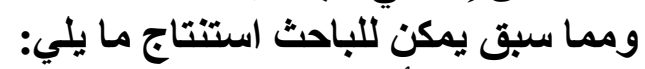
كهي⿻اجمعت الأساليب الإحصائية بين المعالجات الإحصائية البسيطة، وبين المقاييس الإحصائية المتقدمة نسبيا.

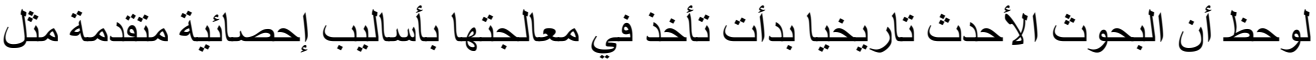

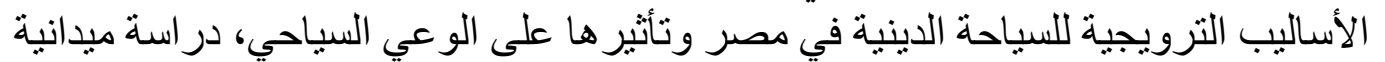

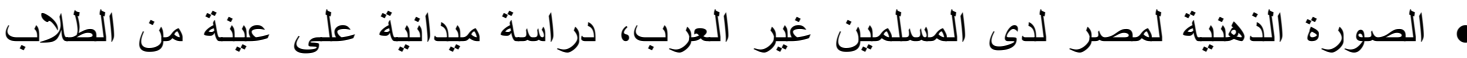

$$
\text { الو افدين بجامعة الأز هر المرن }
$$
• العوامل المؤثرة في تشكيل صورة الولايات المتحدة لاى قادة الرأي الدينيين بعد أحداث

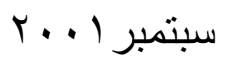

• دور الاتصال في تكوين الصورة الذهنية عن الو لايات المتحدة الأمريكية لدى الثباب اليمني

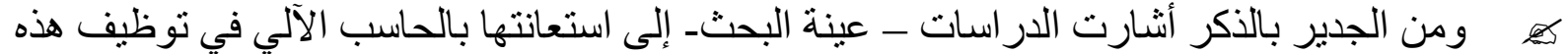

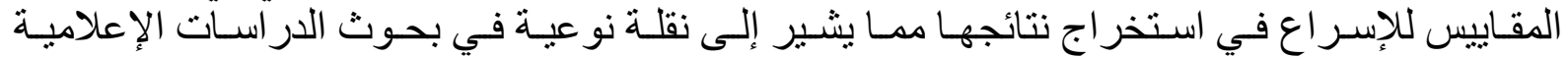

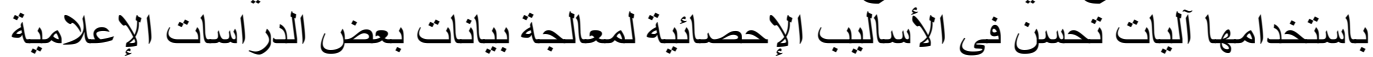

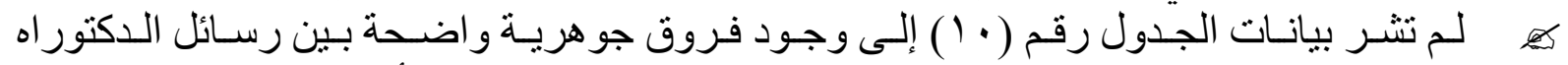

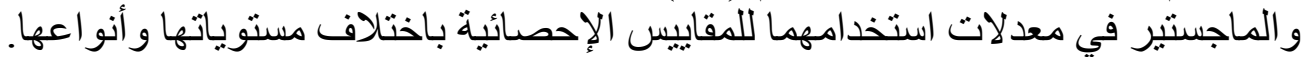

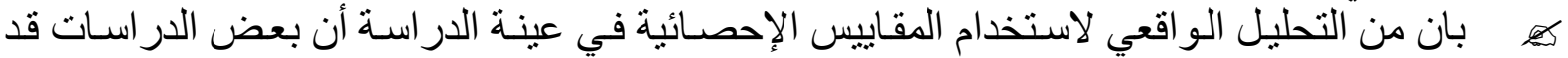

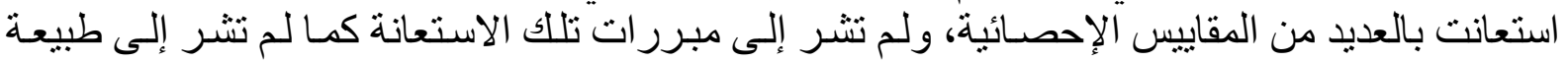

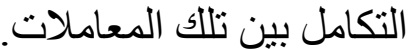

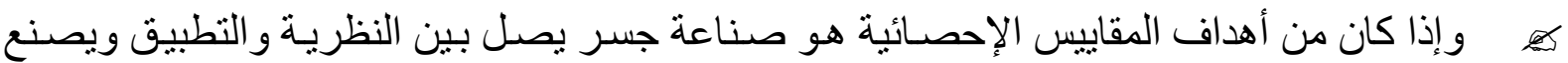

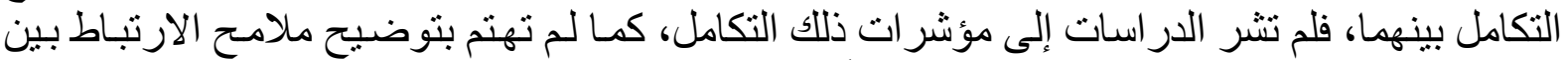
مجمو عات النتائج لتفسير ها في إطار أكثر شمولاًا.

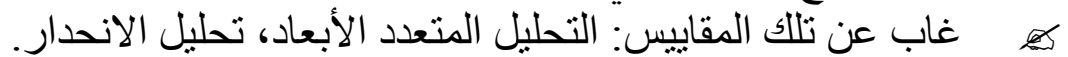

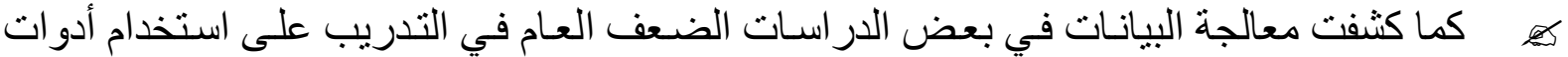

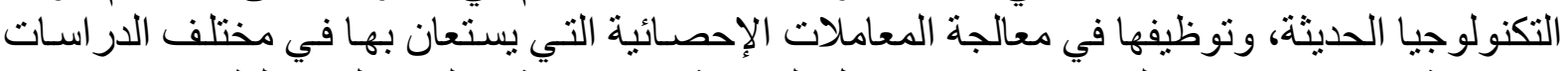

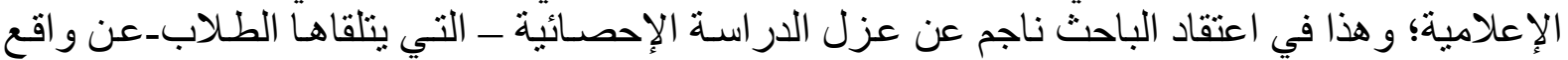

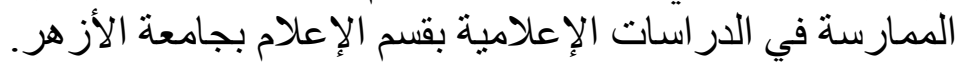




\section{نتائج البحث وتوصياته:}

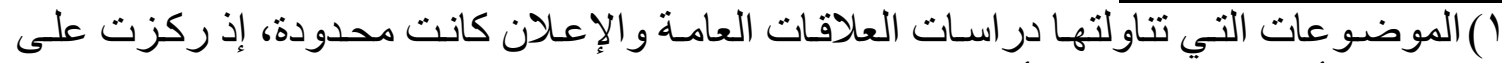

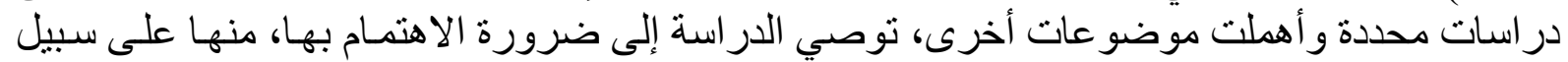

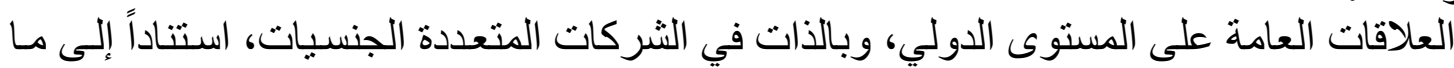
المثال در اسات:

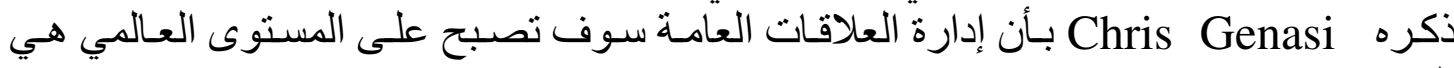
القاعدة. كما لم تحظة در اسـات التأثير ات التكنولوجية على العلاقات العامـة وهو مجال خصب في في حقل

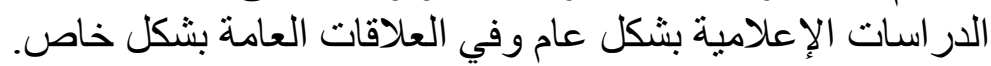

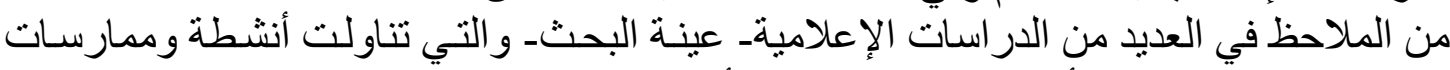

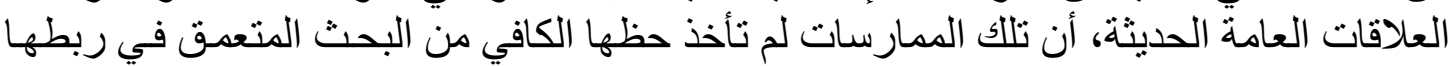

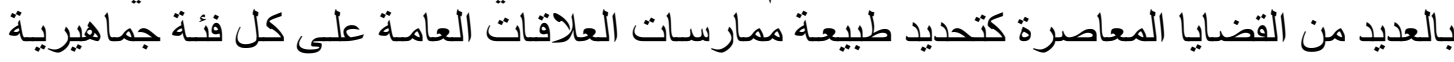

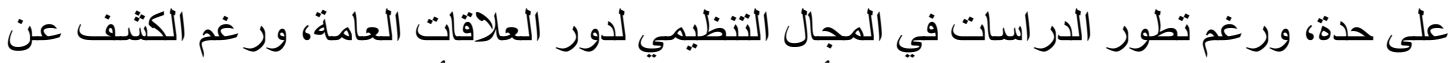

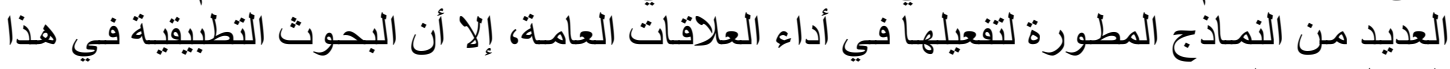

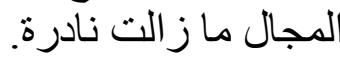

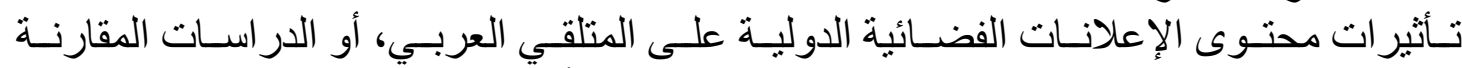

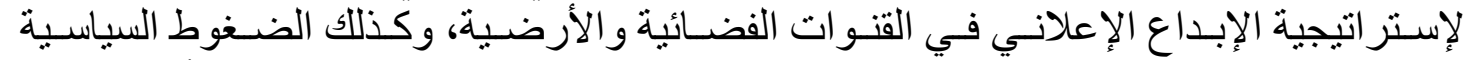

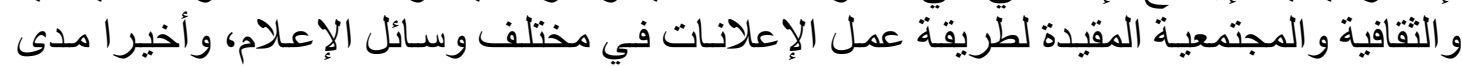

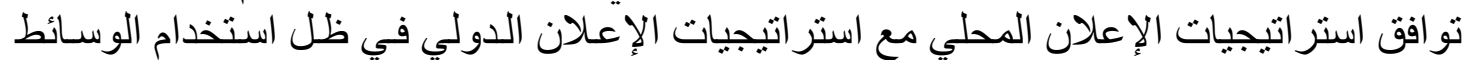
الإعلانية غير التقليدية. • الأهتمام بالقضايا الجديدة المترتبة على استخدام التكنولوجيا وقضايا التدريب و التأهيل الإعلامي.

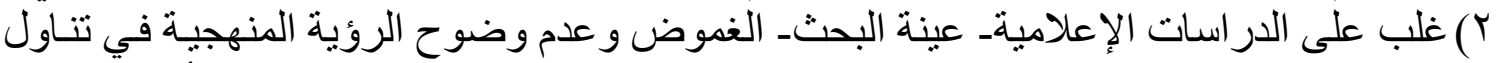

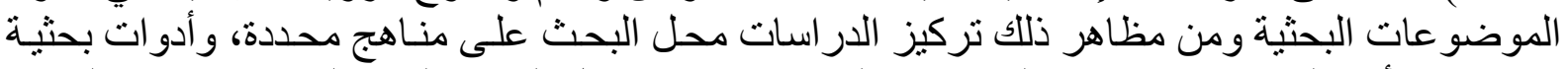

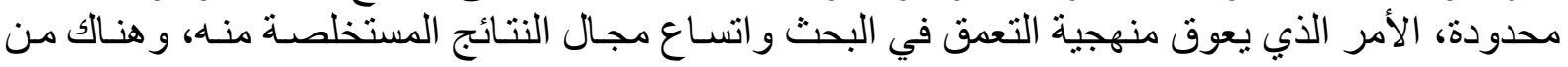

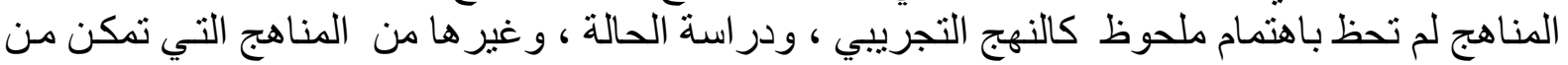

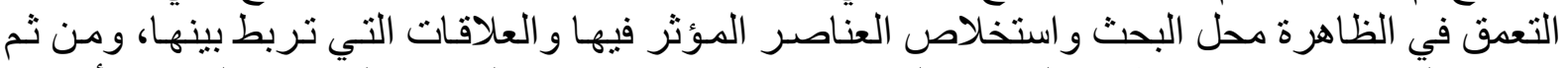

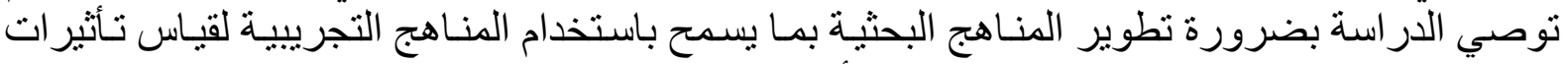

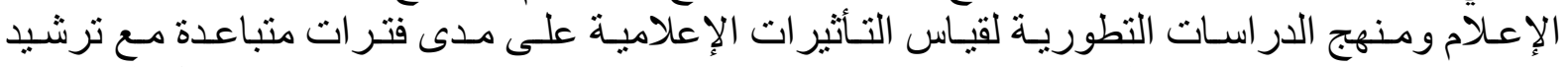

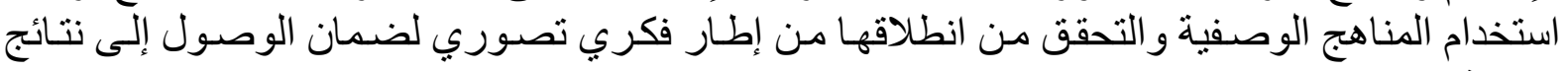

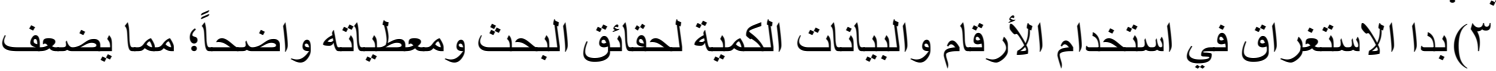
إيجابية .

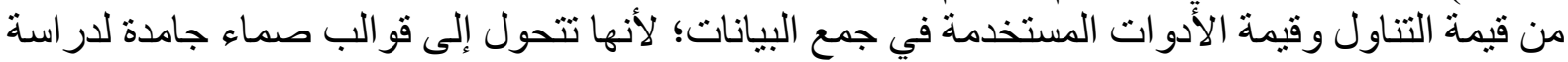

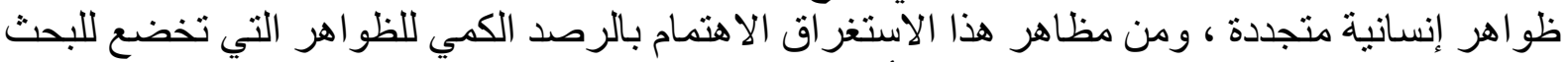

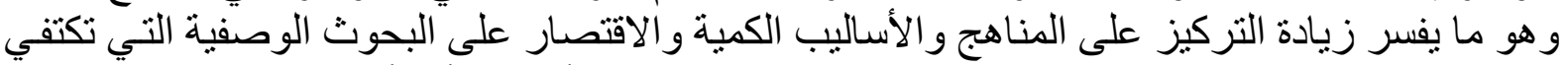

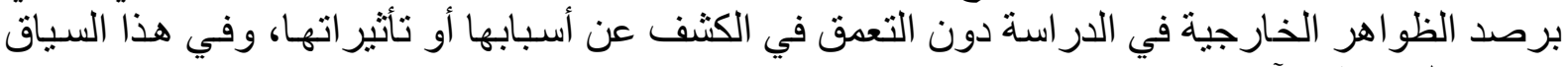
توصي الدر اسة بالآتي:

ضرورة تعزيز اتجاه المدارس النقدية في البحث والتئ التفسير. ضرورة التدريب على مهار ات التعامل الكيفي و التفسير للبيانات و النتائج الكمية. 
استبعاد الكثير من الاستخدامات الإحصائية غير المطلوبة في البحث.

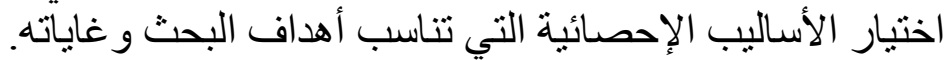

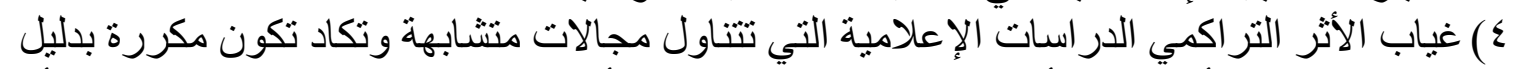

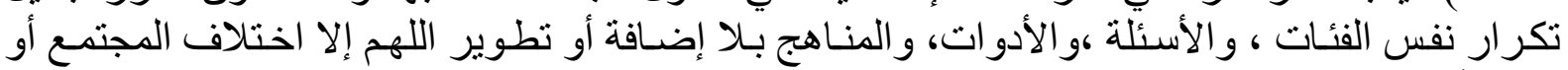

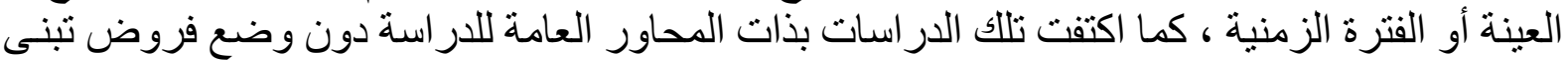

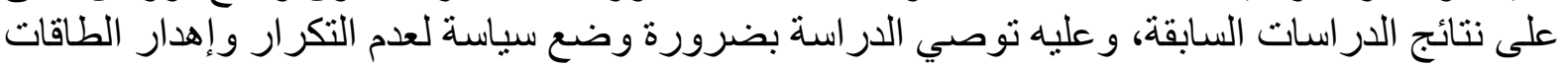

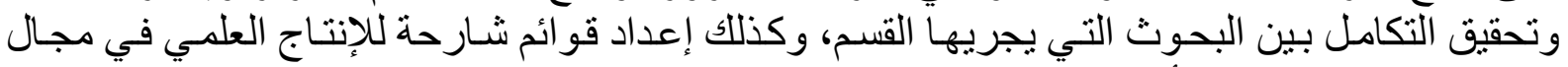
الار اسات الإعلامية على أن يتم ذلك بلى بصورة جماعية.

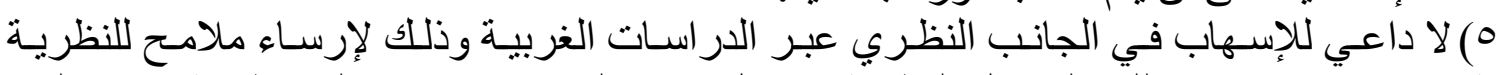

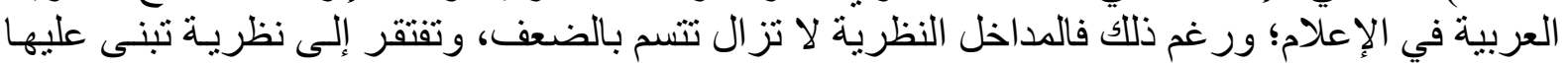

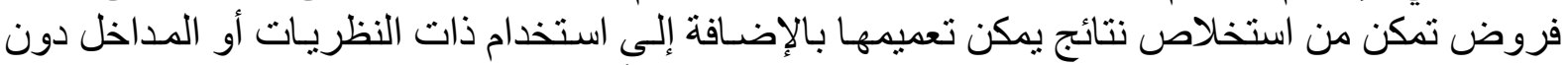

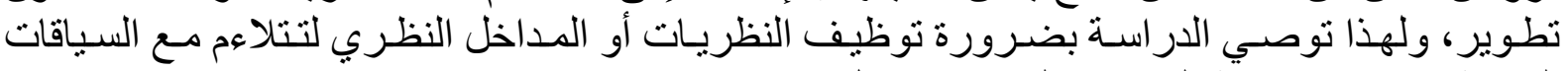

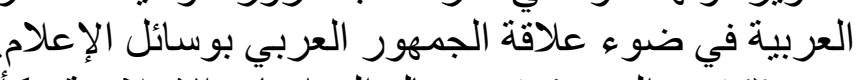

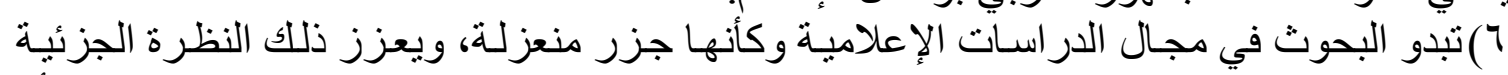

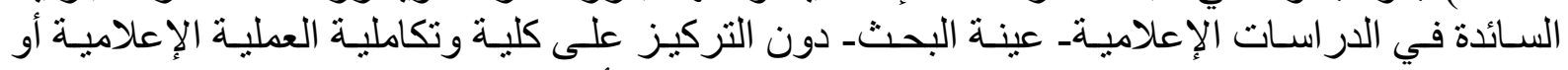

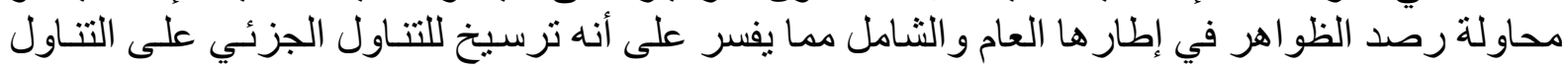

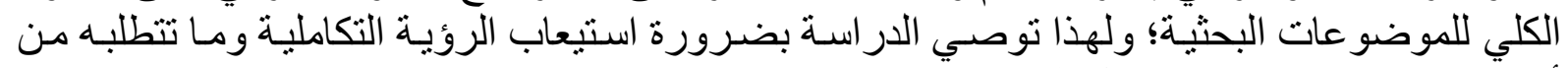

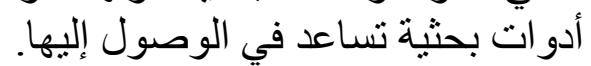




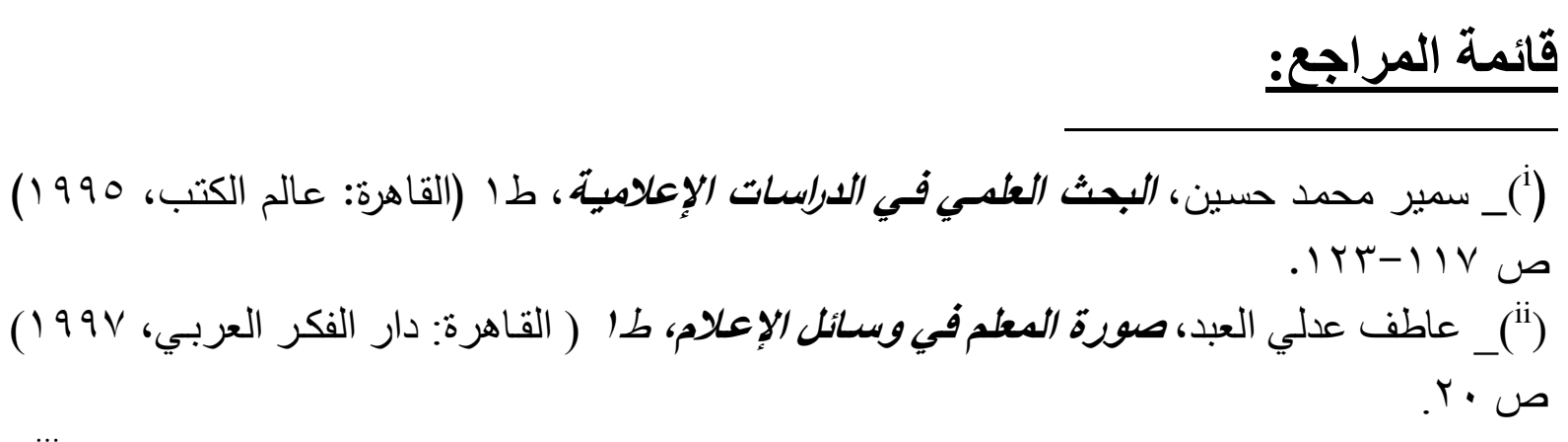

(iii)_ Yahya r. Kamalipourmidia Images Of Arabs, Muslims and the Middle East in the United States: in: Leo A. Gher and Hussein Y. Amin, Civic Discourse and Digital Age Communications In the Middle East (U.S.A. Ablex Publishing Corporation, $r \cdots$. Pp.00-V• .

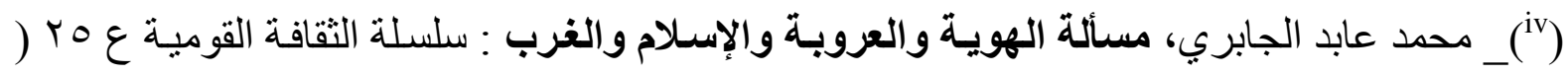

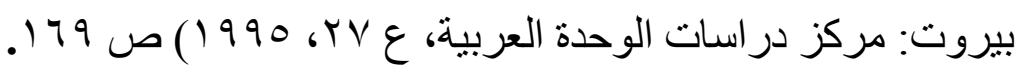

$\left({ }^{v}\right)_{-}$Samuel Huntington, the clash of civilizations, foreign affairs.vol. ${ }^{\vee r}$, no. ${ }^{\Upsilon}$, USA, summer. ${ }^{99 r}$, pp. rr-r $r$.

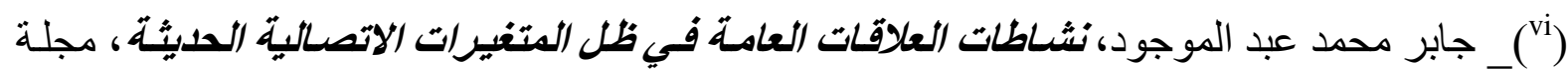

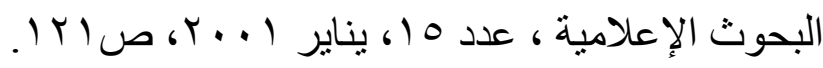
(vii)_David Miller and William Dinan ( $\uparrow \ldots$ ) "The Rise of the P.R. Industry in

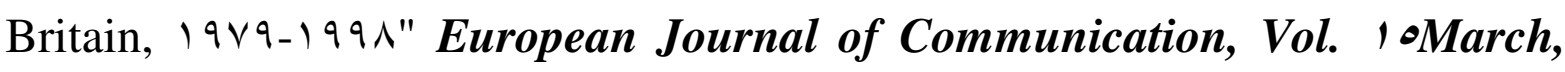
No. 1.P.9. Robert Irwin Wakefield, “ International Public Relations: A Theoretical ) viii( Approach to Excellence Based on a Worldwide Delphi Study (public , Unpublished PhD Thesis, University of Maryland.,"Relations) "The Magic Communication Machine (ix)_Donald k. Wright, (r... Examining the Internet's Impact on Public Relation's Journalism and the Public University of South Alabama, Pp, 7- r .

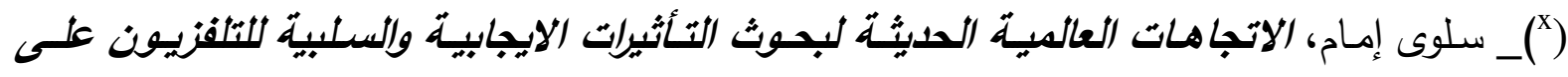

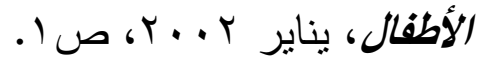

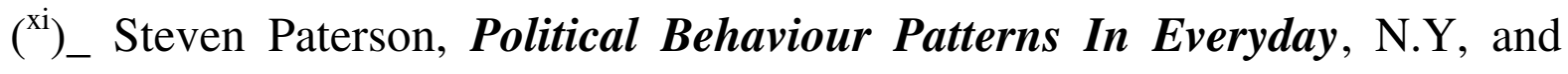
Newbury Park: 199., P. r r9. 
(ألاعلام (xii)

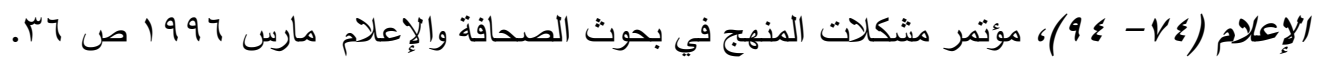

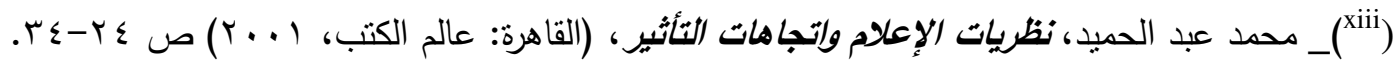

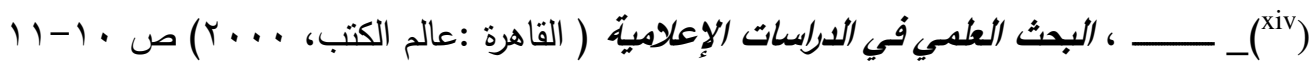

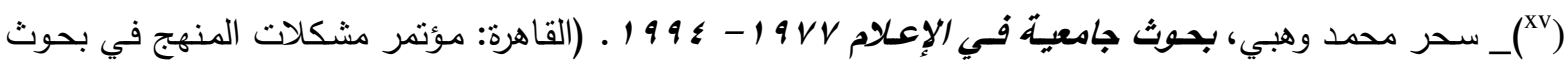

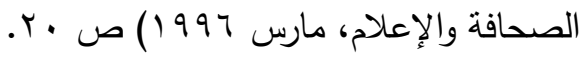

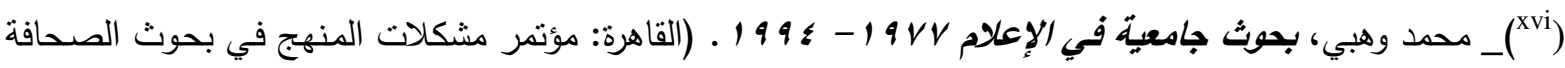

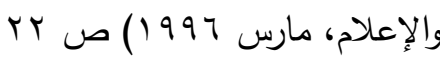

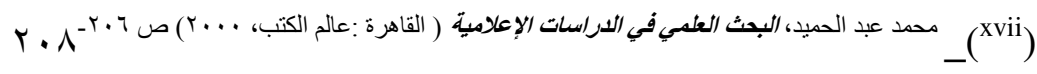

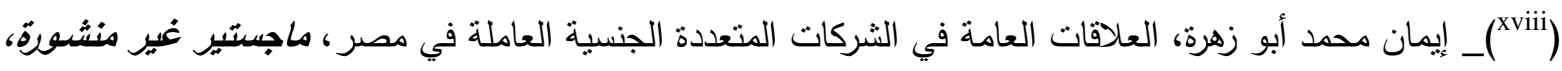

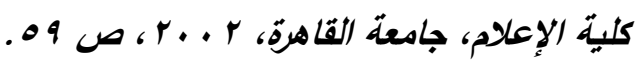
xix) Melvin 1. Defleur and Sandra Ball Rokeach, Theories of Mass Communication, sth ed. ( (New York and Longman, 19^v) pp. rr- $\varepsilon r$.

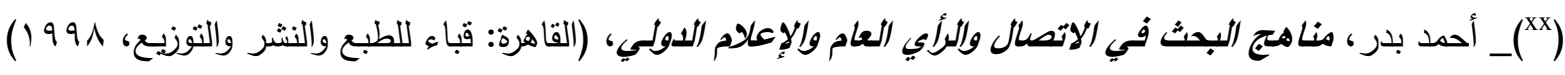
ص rr-T

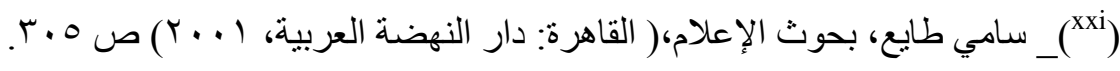

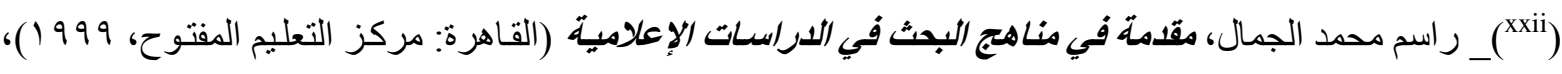
ص عזו. ( ${ }^{\text {xxiii }}$ _ Kenneth d. Bailey, Methods of Social Research, rrd ed., (New York: The Free Press,

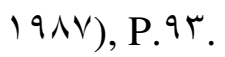

$\left({ }^{\mathrm{xxiv}}\right)_{-}$Mel Churton, Theory and Method, (Hound mills, Macmillan Press, LTD, ץ...) p IV

$\left({ }^{\mathrm{xxv}}\right)_{-}$Therese 1. Baker, Doing Social Research, rrd ed., (Boston: Mc Graw Hill, 1999), P.ITN.

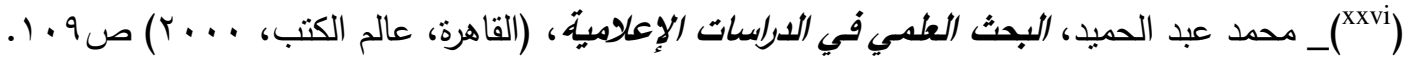

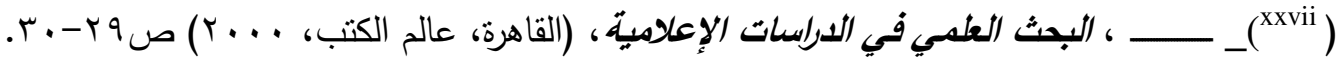

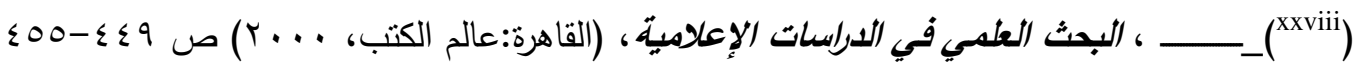

